Aus dem Institut für Neuro- und Sinnesphysiologie

(Prof. Dr. med. S. O. Rizzoli)

im Zentrum Physiologie und Pathophysiologie

der Medizinischen Fakultät der Universität Göttingen

\title{
Investigating the Impact of Hypoxia on Gene Expression in the Brain of a Mouse Model for the Rett Syndrome
}

\author{
INAUGURAL-DISSERTATION \\ zur Erlangung des Doktorgrades für Zahnheilkunde \\ der Medizinischen Fakultät der \\ Georg-August-Universität zu Göttingen
}

vorgelegt von
Susann Özel

aus

Hannover 
Dekan:

I. Berichterstatter:

II. Berichterstatter:

III. Berichterstatter:
Prof. Dr. H.K. Kroemer

PD Dr. Dr. T.U. Manzke

PD Dr. M. Henneke

Tag der mündlichen Prüfung: $\quad$ 02.02.2015 


\section{Table of contents}

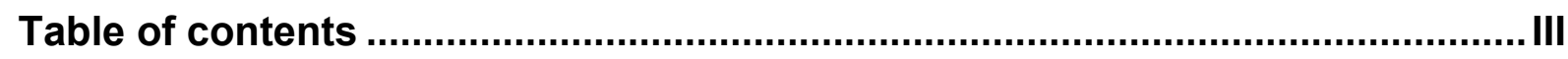

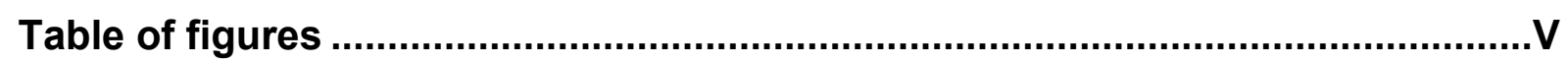

Abbreviations ….........................................................................................VI

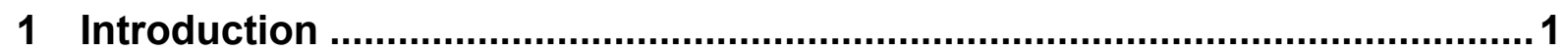

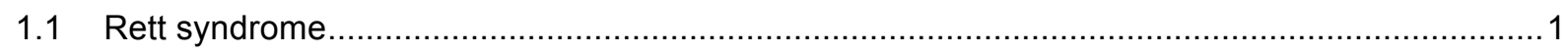

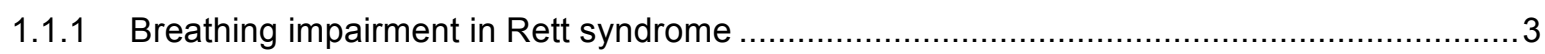

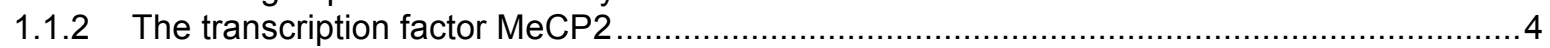

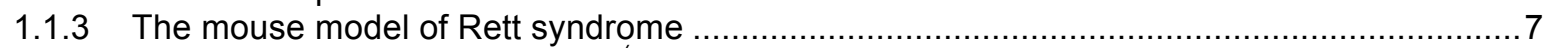

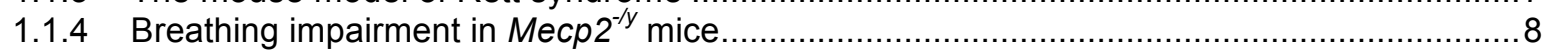

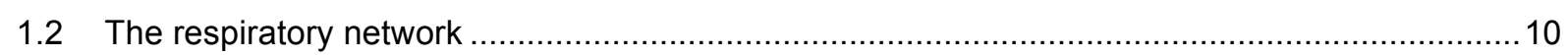

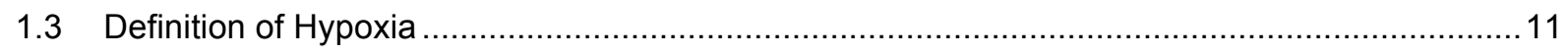

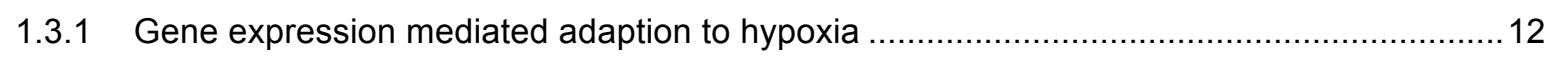

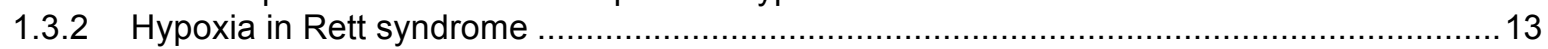

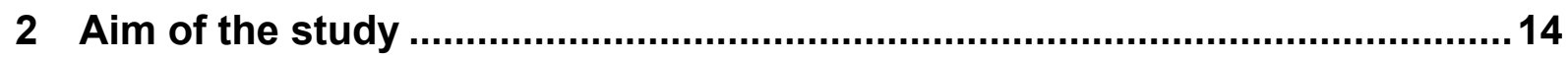

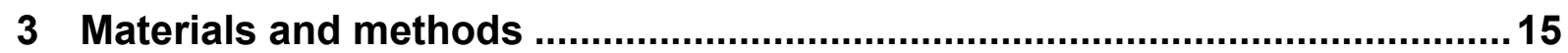

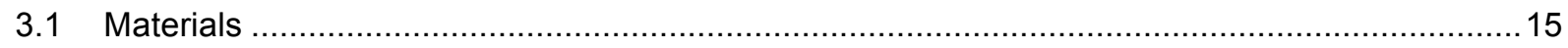

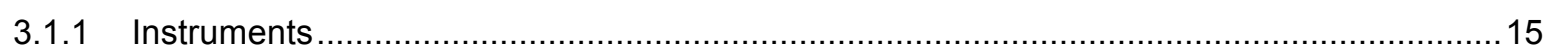

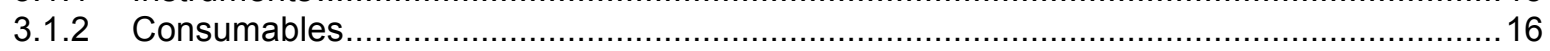

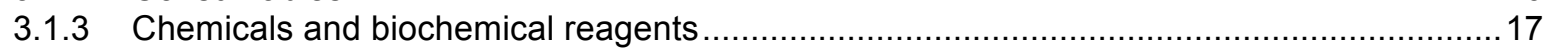

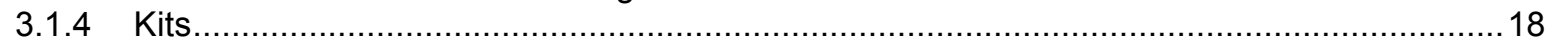

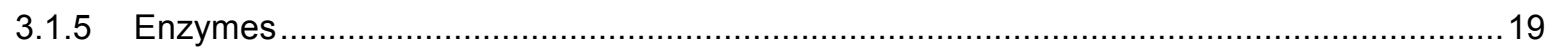

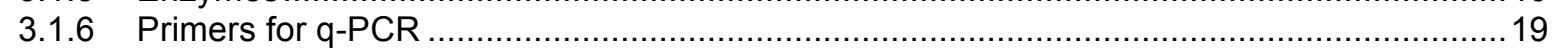

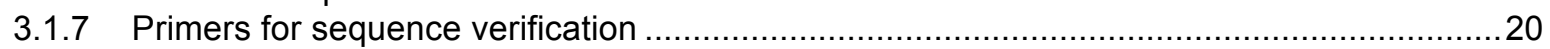

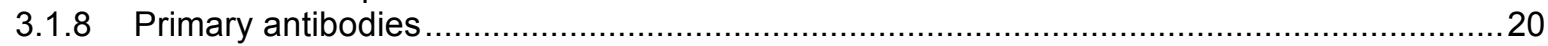

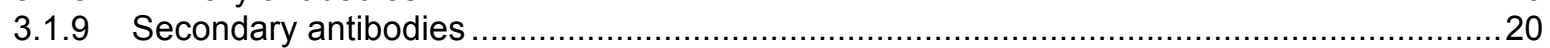

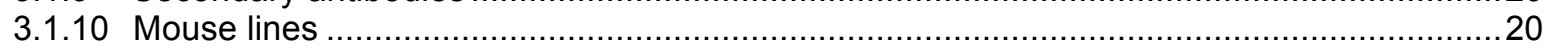

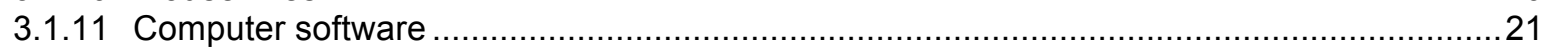

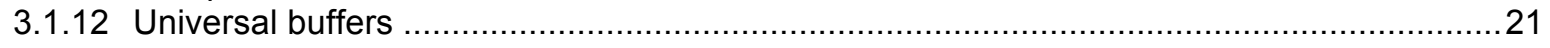

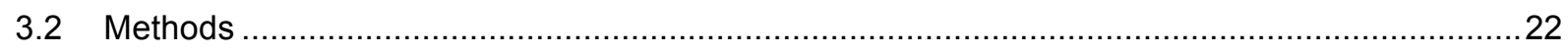

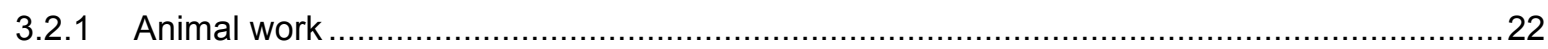

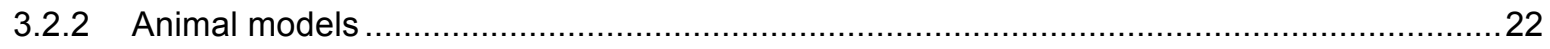

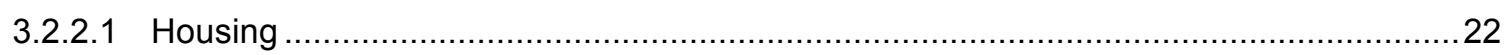

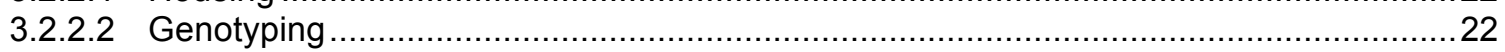

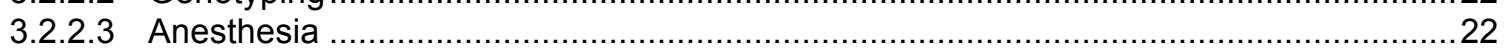

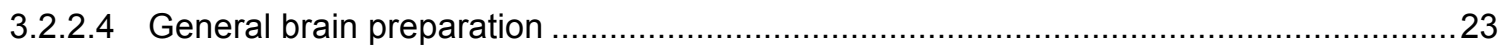

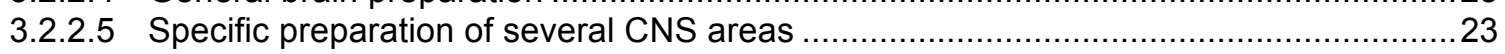

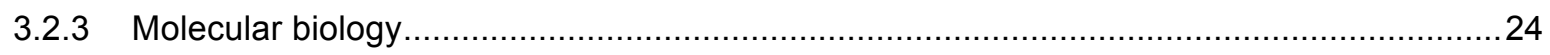

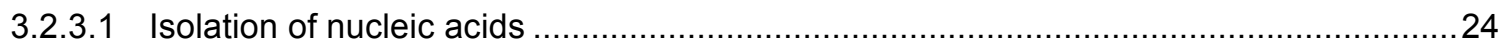

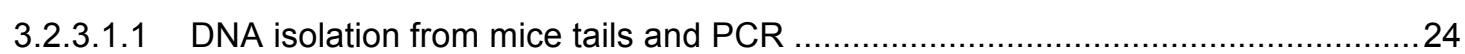

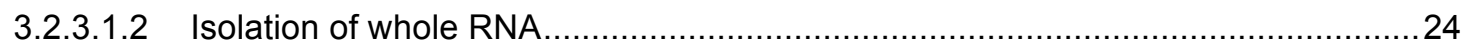

3.2.3.2 Spectrophotometric determination of nucleic acid concentration ...........................26

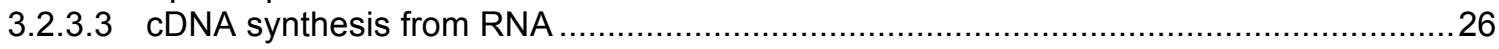

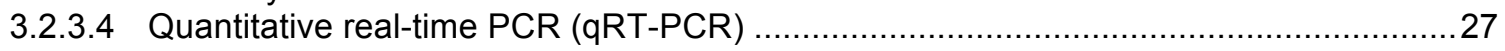




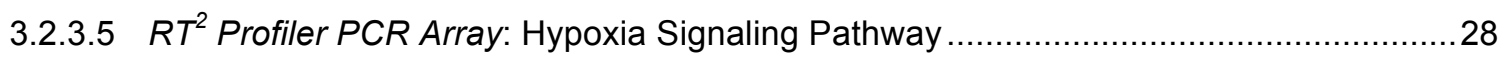

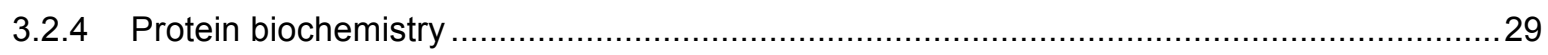

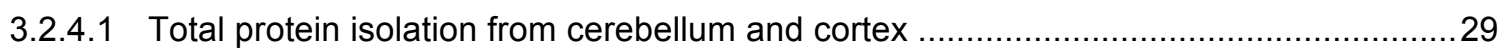

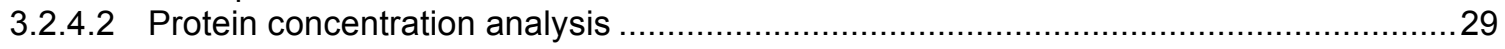

3.2.4.3 Sodium dodecyl sulfate polyacrylamide gel electrophoresis ................................... 30

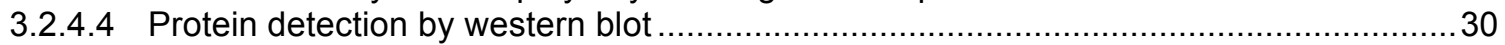

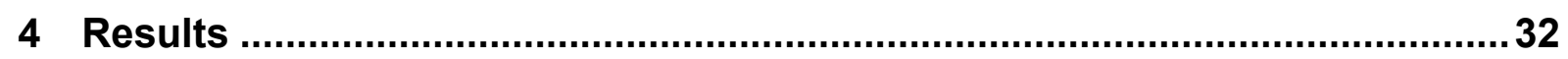

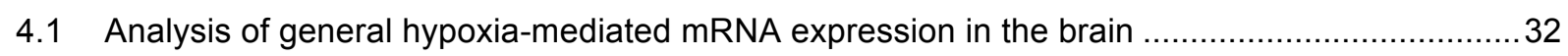

4.2 Systemic analysis of selected hypoxia-mediated mRNA and protein expression in the brain .....35

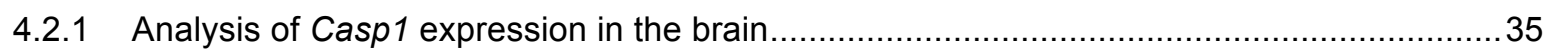

4.2.1.1 Analysis of Casp1 mRNA expression in wt mice in the brain.......................................36

4.2.1.2 Analysis of Casp1 mRNA expression comparing wt to Mecp2 ${ }^{-1 y}$ mice in the brain..........36

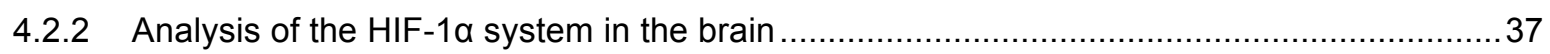

4.2.2.1 Analysis of Hif1a mRNA expression in wt mice in the brain...........................................38

4.2.2.2 Analysis of Hif1a mRNA expression comparing wt to Mecp2 $2^{-y}$ mice in the brain..............38

4.2.2.3 Analysis of HIF-1a protein expression comparing wt to Mecp2 ${ }^{-1 y}$ mice in the brain ........39

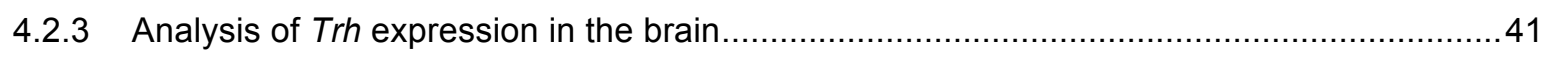

4.2.3.1 Analysis of Trh mRNA expression in wt mice in the brain ........................................42

4.2.3.2 Analysis of Trh mRNA expression comparing wt to Mecp2 ${ }^{-1 y}$ mice in the brain...............42 42

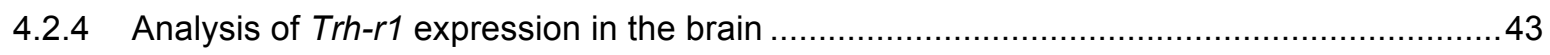

4.2.4.1 Analysis of Trh-r1 mRNA expression in wt mice in the brain ......................................44

4.2.4.2 Analysis of Trh-r1 mRNA expression comparing wt to Mecp2 $2^{-1 y}$ mice in the brain ..........44

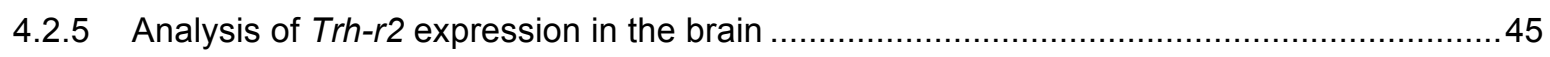

4.2.5.1 Analysis of Trh-r2 mRNA expression in wt mice in the brain .......................................45

4.2.5.2 Analysis of Trh-r2 mRNA expression comparing wt to Mecp $2^{-1 y}$ mice in the brain ..........46

5 Discussion, implications and further research ............................................48

5.1 General hypoxia-mediated mRNA expression is not modified in the brain ...............................48

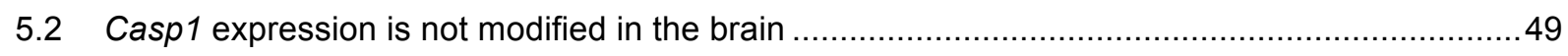

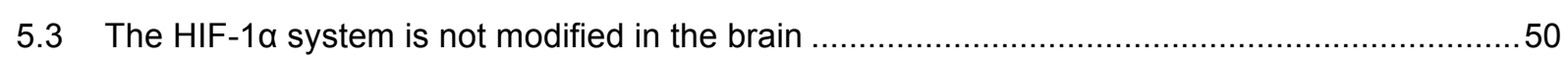

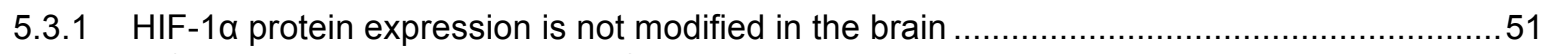

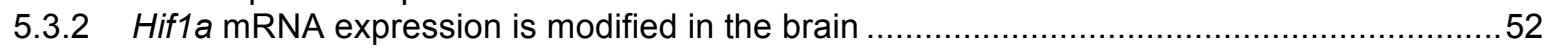

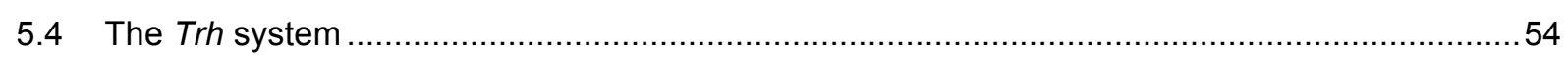

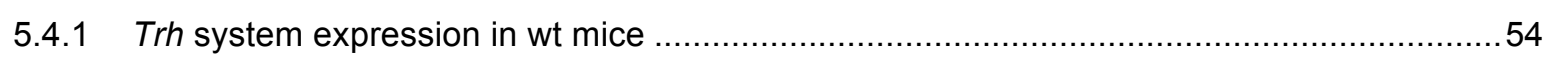

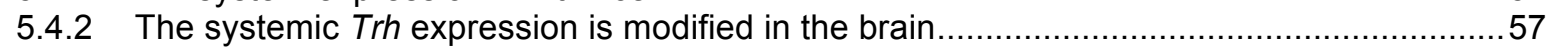

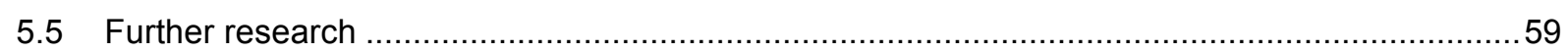

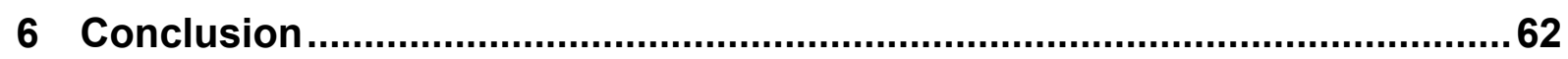

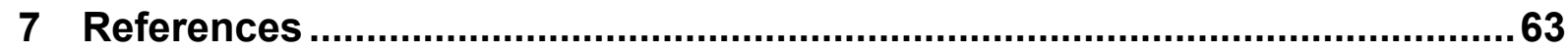




\section{Table of figures}

Figure 1.1 Photograph sequence of a female Rett patient affected by severe breathing problems 3

Figure 1.2 Splicing variants of the human methyl-CpG protein (MeCP2) and its functional domains 5

Figure 1.3 Functions of MeCP2 in chronological research order $\quad 7$

Figure 1.4 Schema of the localization of regions essential for respiratory rhythm generation 11

Figure 3.1 Schema of sagittal section of mouse brain with regions of interest 23

Figure 4.1 mRNA expression of hypoxia related genes comparing wt to Mecp2 $2^{-1 y}$ mice 35

Figure 4.2 Casp1 mRNA expression in wt mice 36

Figure 4.3 Casp1 mRNA expression comparing wt to Mecp2-/y mice 37

Figure 4.4 Hif1a mRNA expression in wt mice $\quad 38$

Figure 4.5 Hif1a mRNA expression comparing wt to Mecp2 ${ }^{-/ y}$ mice 39

Figure 4.6 HIF-1 $\alpha$ western blot comparing wt to Mecp2-/y mice 40

Figure 4.7 HIF-1 1 p protein expression comparing wt to Mecp2 ${ }^{-/ y}$ mice 40

Figure 4.8 Trh mRNA expression in wt mice $\quad 42$

Figure 4.9 Trh mRNA expression comparing wt to Mecp2 $2^{-/ y}$ mice 43

Figure 4.10 Trh-r1 mRNA expression in wt mice $\quad 44$

Figure 4.11 Trh-r1 mRNA expression comparing wt to Mecp2 ${ }^{-/ y}$ mice 445

Figure 4.12 Trh-r2 mRNA expression in wt mice $\quad 46$

Figure 4.13 Trh-r2 mRNA expression comparing wt to Mecp2 ${ }^{-/ y}$ mice 47

Figure 5.1 Mechanisms of TRH $\quad 56$

Figure 5.2 TRH adaption process during hypoxia within the brain of Mecp2 ${ }^{-1 y}$ mice 59 


\section{Abbreviations}

\begin{tabular}{|c|c|}
\hline $1-9$ & \\
\hline $3^{\prime}$ & 3'-phosphate-end \\
\hline $5^{\prime}$ & 5'-phosphate-end \\
\hline $5 \mathrm{hmC}$ & 5-hydroxymethylcytosine \\
\hline \multicolumn{2}{|l|}{ A } \\
\hline A & adenine \\
\hline$a b$ & antibody \\
\hline$A C$ & adenylyl cyclase \\
\hline \multicolumn{2}{|l|}{ B } \\
\hline BDNF & brain derived neurotrophic factor \\
\hline Bdnf & gene coding for BDNF \\
\hline bp & base pair \\
\hline BSA & bovine serum albumin \\
\hline \multicolumn{2}{|l|}{$C$} \\
\hline C-terminus & carboxy terminus \\
\hline cAMP & cyclic adenosine monophosphate \\
\hline Casp1 & caspase 1 (gene) \\
\hline cDNA & complementary deoxyribonucleic acid \\
\hline $\mathrm{cm}$ & centimeter \\
\hline CNS & central nervous system \\
\hline $\mathrm{CpG}$ & cytosine-phosphate-guanine dinucleotide \\
\hline CREB1 & cAMP responsive element binding protein 1 \\
\hline \multicolumn{2}{|l|}{ D } \\
\hline d & day \\
\hline $\mathrm{Da}$ & dalton \\
\hline $\mathrm{dd}_{2} \mathrm{O}$ & double distilled water \\
\hline DNA & deoxyribonucleic acid \\
\hline dNTP & deoxynucleotide triphosphate \\
\hline DRC & dorsal respiratory column \\
\hline DRG & dorsal respiratory group \\
\hline \multicolumn{2}{|l|}{$E$} \\
\hline e.g. & exempli gratia \\
\hline
\end{tabular}




\begin{tabular}{|c|c|}
\hline EDTA & ethylenediaminetetraacetic acid \\
\hline \multicolumn{2}{|l|}{$\mathbf{F}$} \\
\hline fig. & figure \\
\hline \multicolumn{2}{|l|}{ G } \\
\hline g & relative centrifugal force (CRF) \\
\hline G & guanine \\
\hline Gapdh & glyceraldehyde 3-phosphate dehydrogenase (gene) \\
\hline \multicolumn{2}{|l|}{ H } \\
\hline h & hour \\
\hline HIF & hypoxia-inducible factor \\
\hline Hif1a & hypoxia-inducible factor $1 \alpha$ (gene) \\
\hline HRP & horseradish peroxidase \\
\hline \multicolumn{2}{|l|}{ I } \\
\hline ID & interdomain \\
\hline Igfbp1 & insulin-like growth factor binding protein 1 (gene) \\
\hline 10 & inferior olive \\
\hline $1 \mathrm{O}_{\mathrm{Pr}}$ & inferior olive, principal nucleus \\
\hline \multicolumn{2}{|l|}{ K } \\
\hline k & kilo \\
\hline $\mathrm{kDa}$ & kilodalton, unit for molecular mass \\
\hline ko & knockout, MeCP2 ${ }^{-1 y}$ model \\
\hline \multicolumn{2}{|l|}{$\mathbf{L}$} \\
\hline I & lateral \\
\hline \multicolumn{2}{|l|}{ M } \\
\hline $\mathrm{m}$ & milli \\
\hline M & moles per liter \\
\hline MBD & methyl-CpG-binding domain \\
\hline MECP2 & human gene encoding for MECP2 \\
\hline MeCP2 & methyl-Cpg-binding protein 2 (human and mouse) \\
\hline Mecp2 & mouse gene encoding for MeCP2 \\
\hline $\mathrm{mg}$ & milligram \\
\hline $\mathrm{MgCl}_{2}$ & magnesium chloride \\
\hline $\min$ & minute \\
\hline $\mathrm{mM}$ & millimolar \\
\hline
\end{tabular}




\begin{tabular}{|c|c|}
\hline mRNA & messenger ribonucleic acid \\
\hline $\mathrm{mS} \sin 3 \mathrm{~A}$ & corepressor of MeCP2 \\
\hline \multicolumn{2}{|l|}{$\mathbf{N}$} \\
\hline $\mathrm{n}$ & nano \\
\hline $\mathrm{n}=$ & number of experiments \\
\hline N-terminus & amino terminus \\
\hline n.s. & not significant \\
\hline NA & nucleus ambiguous \\
\hline $\mathrm{NaOH}$ & sodium hydroxide \\
\hline $\mathrm{NCBI}$ & National Center for Biotechnology Information \\
\hline NLS & nuclear localization sequence \\
\hline $\mathrm{nm}$ & nanometer \\
\hline $\mathrm{nM}$ & nanomolar \\
\hline NTS & nucleus tractus solitarius \\
\hline \multicolumn{2}{|l|}{$\mathbf{0}$} \\
\hline OD & optical density (absorbance) \\
\hline $\mathrm{OH}$ & hydroxyl group \\
\hline \multicolumn{2}{|l|}{$\mathbf{P}$} \\
\hline P40 & postnatal stage $\mathrm{P} 40$, postnatal 40 days old \\
\hline PBS & phosphate buffered saline \\
\hline PCR & polymerase chain reaction \\
\hline Pdia2 & protein disulfide isomerase associate 2 (gene) \\
\hline pre-BötC & pre-Bötzinger complex \\
\hline \multicolumn{2}{|l|}{$\mathbf{Q}$} \\
\hline qRT-PCR & quantitative real-time PCR \\
\hline \multicolumn{2}{|l|}{$\mathbf{R}$} \\
\hline r & rostral \\
\hline RNA & ribonucleic acid \\
\hline rpm & revolutions per minute \\
\hline rRNA & ribosomal RNA \\
\hline RT & room temperature \\
\hline RT-PCR & reverse transcription polymerase chain reaction \\
\hline RTT & Rett syndrome \\
\hline \multicolumn{2}{|l|}{$\mathbf{S}$} \\
\hline S & Svedberg unit \\
\hline
\end{tabular}


Abbreviations

\begin{tabular}{|l|l|}
\hline sec & second \\
\hline sm & size marker \\
\hline $\mathbf{T}$ & \\
\hline T & thymine \\
\hline$T_{3}$ & triiodothyronine \\
\hline $\mathrm{T}_{4}$ & thyroxine \\
\hline tab. & table \\
\hline Taq & thermus aquaticus \\
\hline TBS & tris buffered saline \\
\hline TRD & transcription repressor domain \\
\hline TRH & thyrotropin-releasing hormone \\
\hline TRH-R1 or -R2 & thyrotropin-releasing hormone receptor 1 or 2 \\
\hline TSH & thyroid-stimulating hormone \\
\hline $\mathbf{U}$ & \\
\hline U & units \\
\hline $\mathbf{V}$ & \\
\hline V & volume \\
\hline Vegf & gene encoding for vascular endothelial growth factor \\
\hline VRC & ventral respiratory column \\
\hline VRG & ventral respiratory group \\
\hline $\mathbf{W}$ & \\
\hline wt & wild type \\
\hline $\mathbf{X}$ & \\
\hline$\lambda$ & lambda (wavelength) \\
\hline & \\
\hline
\end{tabular}




\section{Introduction}

\subsection{Rett syndrome}

Rett syndrome (RTT; ICD10: F84.2) has been classified as an autism spectrum developmental disorder and was first described by the Vienna physician Andreas Rett in 1966 (Rett 1966). RTT predominantly affects female children with a prevalence of 1 in 15,000 to 1 in 10,000 live births (Hagberg et al. 1985). Thereby, it represents one of the most numerous genetic factors for mental retardation in females. Only Down's syndrome occurs more frequently (Hoffbuhr et al. 2001).

RTT is strongly associated with mutations of the MECP2 gene, which is located on the long arm of the X-chromosome (Xq28) (Amir et al. 1999). 90\% of these mutations occur in the male germline spontaneously (Trappe et al. 2001). Moreover, RTT shows strong gynecotropism. While males with MECP2 mutations almost always die in their first year of life, hemizygous females manage to go on living in the face of their severe symptoms (Villard 2007).

Although a patient's phenotype can vary depending on the X-chromosome inactivation pattern and the kind of MECP2 mutation (Schanen et al. 1997), Hagberg and WittEngerström (1986) established a four-stage classification of developmental progression and symptoms of Rett patients, which is highly acknowledged around the world. The stages of Hagberg and Witt-Engerström's (1986) classification are illustrated in Figure 1.1.

First stage (six to 18 months of age): After a normal neurological development stage until the sixth month of age, the "early onset stagnation stage" sets in. RTT patients of this age show motor progress deceleration, disinterest, activity reduction, small-sized head circumference, as well as the inability to keep eye-toeye contact.

Second stage (first to third year of age): During the "rapid destructive stage" patients demonstrate a loss of already learned skills, such as language and purposeful hand use. Moreover, the RTT disease manifests itself in stereotypical hand movements, social and emotional retraction, phases of screaming and 
crying, epileptic seizures, as well as dysfunction of sensory perception and integration, hardly distinguishable from autism.

Third stage (second to tenth year of age): In the "pseudo-stationary stage" RTT patients show fewer expressions of autistic behavior and irritability. However, physiological disturbances, such as apraxia, ataxia, and hand stereotypes likewise increase. In this stage, for example, first striking breathing symptoms leading to episodic "press" hyperventilation of RTT patients occur (Hagberg et al. 1985). Moreover, RTT patients show pronounced teeth grinding and oral bruxism habits, caused by a high palatal arch, which leads to teeth mobility class II and momentous tooth attrition (Fuertes-González et al. 2011).

Fourth stadium (tenth year of age onwards): In the "late motor deterioration stage" RTT patients demonstrate cognitive proceedings on the one hand, but weakness, cachexia, and spasticity on the other. Most RTT patients are obliged to use a wheelchair from now on, which often leads to further diseases, such as scoliosis (Han et al. 2012). Individuals affected by RTT only have a limited life expectancy of seven to 35 years (20 years in average) (Laurvick et al. 2006).

To improve their life quality, RTT patients can take advantage of therapies such as music therapy, physical therapy, speech therapy, or ergo therapy (Hanks et al. 1986). To maintain sufficient nutritional status patients are often fed via a stomach tube or percutaneous endoscopic gastrostomy (PEG) (Oddy et al. 2007). Furthermore, patients who exhibit seizure activity are treated with anticonvulsant pharmaceutics (Glaze et al. 1998). Unfortunately, however, to date no causal therapy for patients suffering under the RTT disease exists. 

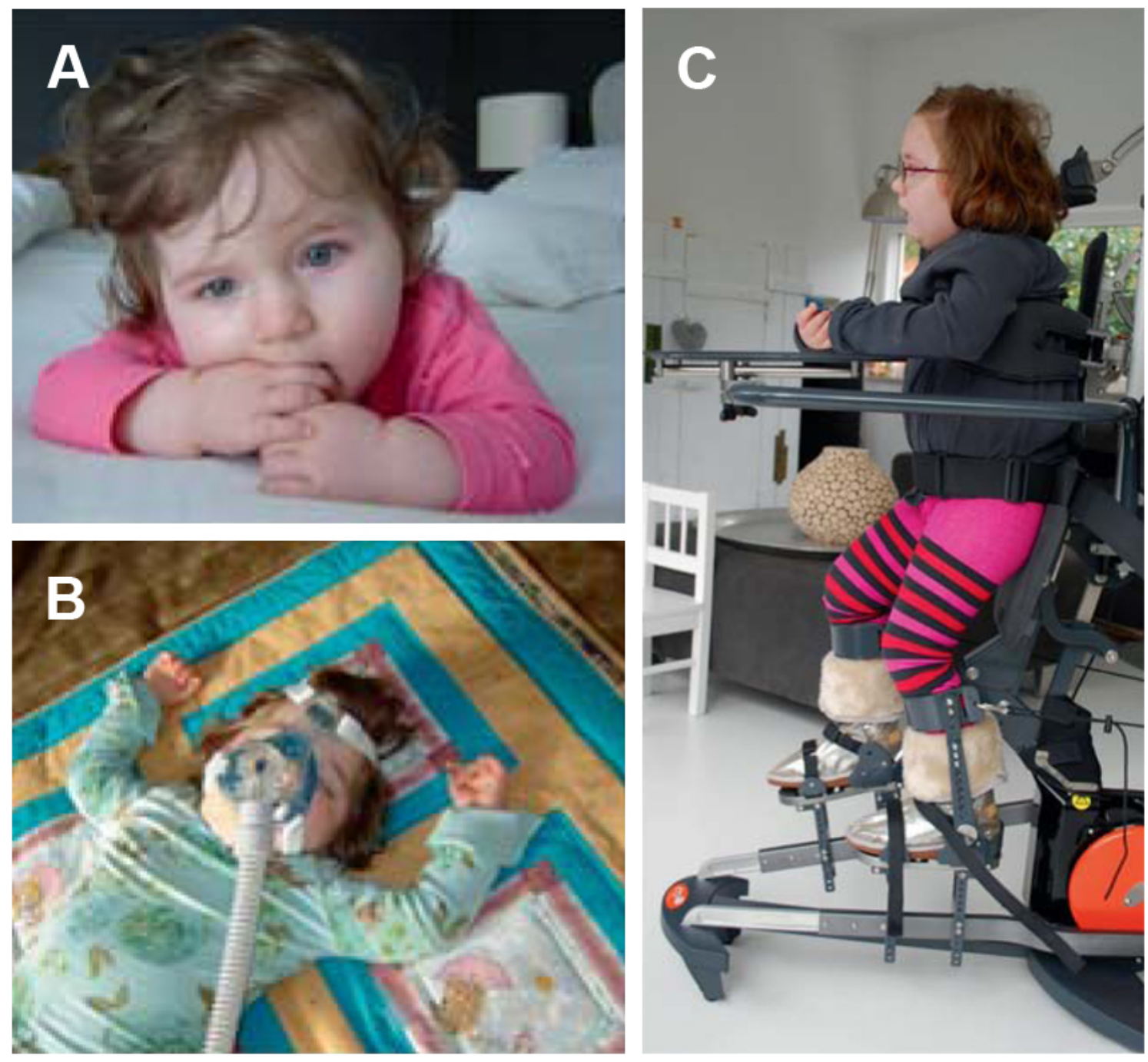

Figure 1.1 Photograph sequence of a female Rett patient affected by severe breathing problems

(A) Patient shows the first symptoms at the age of 9 months, particularly apathetic behavior. (B) At the age of 3 years the patient needs Biphasic Positive Airway Pressure (BIPAP) to provide the oxygen due to breathing disturbances. (C) At the age of 5 years she is reliant on a walker (model adapted from Smeets et al. 2012).

\subsubsection{Breathing impairment in Rett syndrome}

As shown above, one of the devastating features of the RTT syndrome are breathing aberrations such as air swallowing (Morton et al. 2000), breath holding, shallow breathing, Cheyne-Stokes breathing, Biot's breathing (Julu et al. 2001), Valsalva's maneuvers (Southall et al. 1988), episodic hyperventilation (Ren et al. 2012), as well as hypoventilation (Hagebeuk et al. 2012). The breathing aberrations of RTT patients usually start with the age of five to ten years (Julu et al. 2001) and can be observed both during day- as well as nighttime (Rohdin et al. 2007, Weese-Mayer et al. 2008, d'Orsi et al. 2009). $50 \%$ of all RTT patients suffer from breathing aberrations. $25 \%$ of these RTT patients under hyperventilation, often leading to central lack of inspiration 
(Gökben et al. 2012). These breathing arrests are normally accompanied with a decrease of oxygen saturation to less than $50 \%$ of the norm (Southall et al. 1988). Central apnea lasting longer than $45 \mathrm{~s}$ can lead to life threatening circumstances and even to sudden death (Glaze 2005). It is assumed that repetitive hypoxic conditions lead to brain injury, which provokes typical neurologic symptoms in RTT patients. Because so far no preventative therapy for RTT patients has been established, it is not surprising that a strong research interest in breathing disturbances exists.

\subsubsection{The transcription factor MeCP2}

The methyl CpG (Cytidin, phosphate, Guanine) binding protein (MeCP) 2, named according to its ability to bind to methylated DNA, is part of a protein family with a characteristic methyl-CpG-binding domain (MBD) (see Figure 1.2) (Nan et al. 1993). In human as well as in mice, the MECP2/Mecp2 gene resides on the $\mathrm{X}$ chromosome and comprises four exons (see Figure 1.2) (Quaderi et al. 1994, D'Esposito et al. 1996). 
Introduction

A

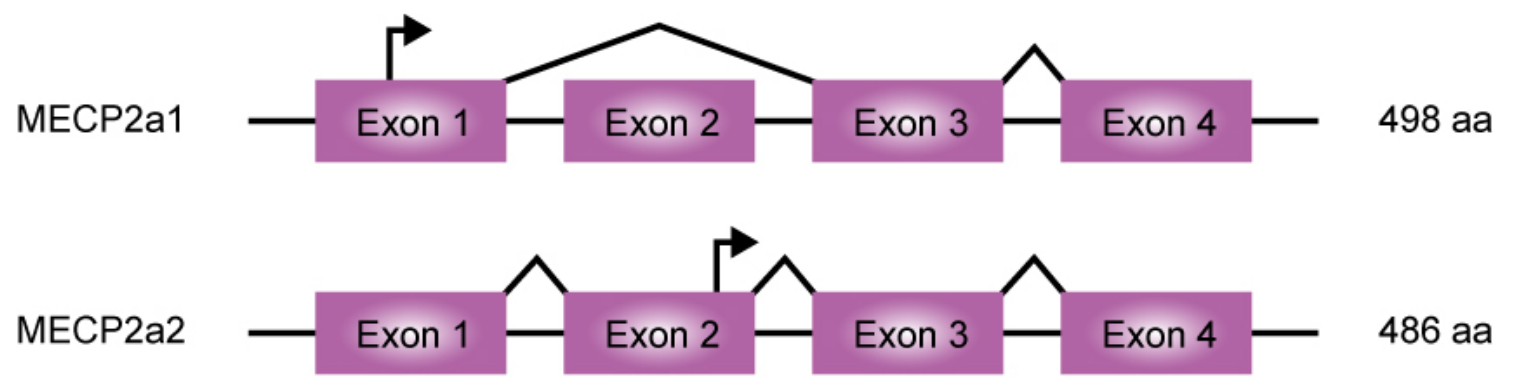

B

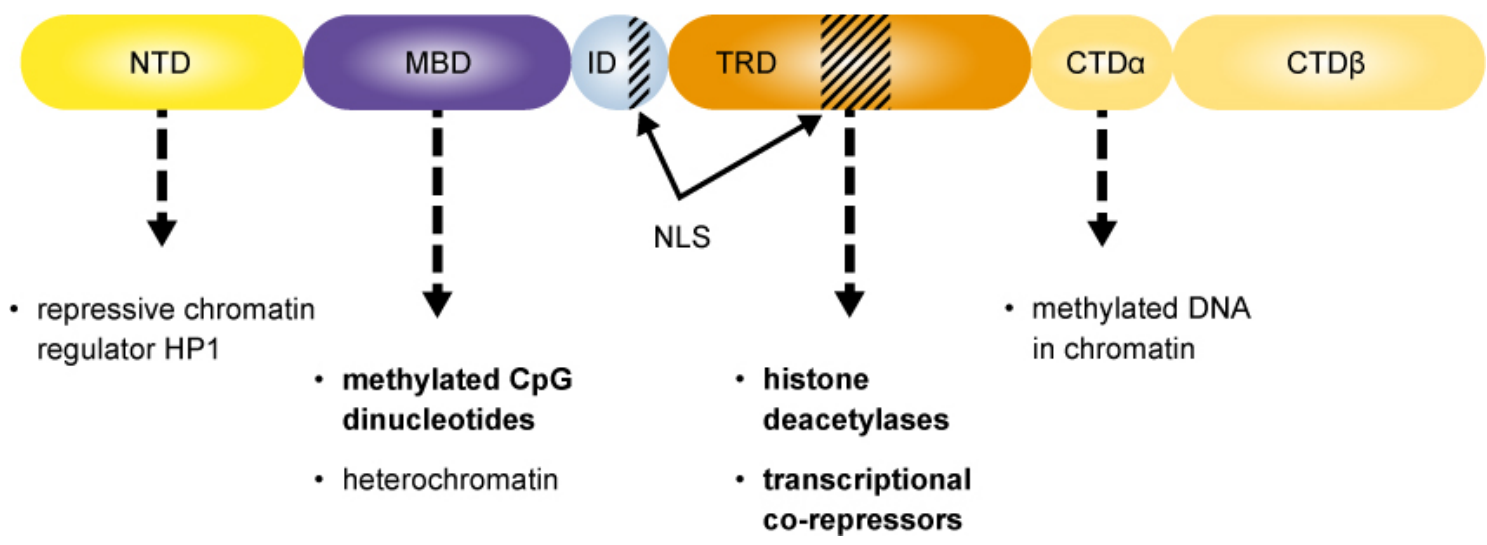

Figure 1.2 Splicing variants of the human methyl-CpG protein (MeCP2) and its functional domains

(A) Two isoforms of the MeCP2 protein, MeCP2_e1 and MeCP2_e2, are generated by alternative splicing. The arrows demonstrate alternative starting points for the translation. (B) Regardless of the different $\mathrm{N}$-termini, both MeCP2 isoforms possess identical domains; (Model adapted from Gadalla et al. 2011). Abbreviations: N-terminal domain (NTD), methyl-CpG binding domain (MBD), interdomain (ID), transcription repressor domain (TRD), C-terminal domain (CTD), nuclear localization sequence (NLS), heterochromatin protein 1 (HP1). The arrows below each domain indicate primary interactors (black) as well as secondary binding partners (grey).

Alternative splicing of exon 2 results in the two different splice variants MeCP2e1 and MeCP2e2. The protein coded by MeCP2e1 mRNA, which is the dominant splice variant in the brain, has a larger $\mathrm{N}$-terminus in comparison to protein translated by the MeCP2e2 mRNA (Mnatzakanian et al. 2004, Kriaucionis and Bird 2004).

The MeCP2 protein (Figure 1.2 B) is composed of 486 amino acids and contains a Nterminal MBD (Nan et al. 1993), a central nuclear localization sequence (NLS), and a C-terminal transcription repression domain (TRD) (Nan et al. 1997). The NLS exists inside TRD and transports the protein into the nucleus (Nan et al. 1997). By means of the MBD, MeCP2 binds to DNA with symmetrically methylated CpG's (Nan et al. 
1993). In particular, TRD has been shown to interact with the co-repressor mSin3A, which leads to the recruitment of histone deacetylases 1 and 2 (HDAC1/2). Histone deacetylation is associated with a heterochromatin formation, which itself is closely linked to the major functions of MeCP2 - chromosome and gene silencing (Jones et al. 1998). Hence, MeCP2 is involved in chromatin remodeling (Mandrioli 2007), gene repression, X-chromosome inactivation (Li 2002), deactivation of foreign DNA elements within genome (Hendrich and Tweedie 2003), and genomic imprinting (Barlow 1994) (Figure 1.3 A-D). Moreover, many genes have been identified as being directly suppressed by MeCP2, such as ubiquitin-protein ligase E3A (Ube3a), gammaaminobutyric acid receptor subunit beta-3 (Gabrb3), corticotropin releasing hormone (Crh), distal-less homeobox 5 (D/x5), and brain-derived neurotrophic factor (Bdnf, see 1.1.4 Breathing impairment in $M e c p 2^{-/ y}$ mice) (Nan et al. 1997, Samaco et al. 2005, Chen et al. 2003, Horike et al. 2005, Martinowich et al. 2003).

However, besides its function as a gene repressor MeCP2 is also known to activate RNA expression (Zhou 2006). MeCP2 activates RNA expression by interacting with the transcriptional activator CAMP responsive element binding protein 1 (CREB1) (Chahrour et al. 2008). MeCP2 has a strong binding capacity towards 5hydroxymethylcytosine $(5 \mathrm{hmC})$. Moreover, an increased $5 \mathrm{hmC}$ expression is interlinked with an increased gene expression. Therefore, it is strongly suggested that MeCP2 functions as an immediate facilitator of gene expression (Mellén et al. 2012). Additionally, depending on the specific posttranslational modification pattern, which includes phosphorylation, ubiquitylation, and acetylation of MeCP2, the protein is even able to change its role regarding a gene transiently: It allows MeCP2 to act as a regulator of gene expression as well as a repressor of genes (Gonzales et al. 2012). Due to the Janus-faced character of gene repression and activation in the process of chromatin formation, MeCP2 is not only regarded as a simple repressor, but as a global chromatin regulator. 
A

B
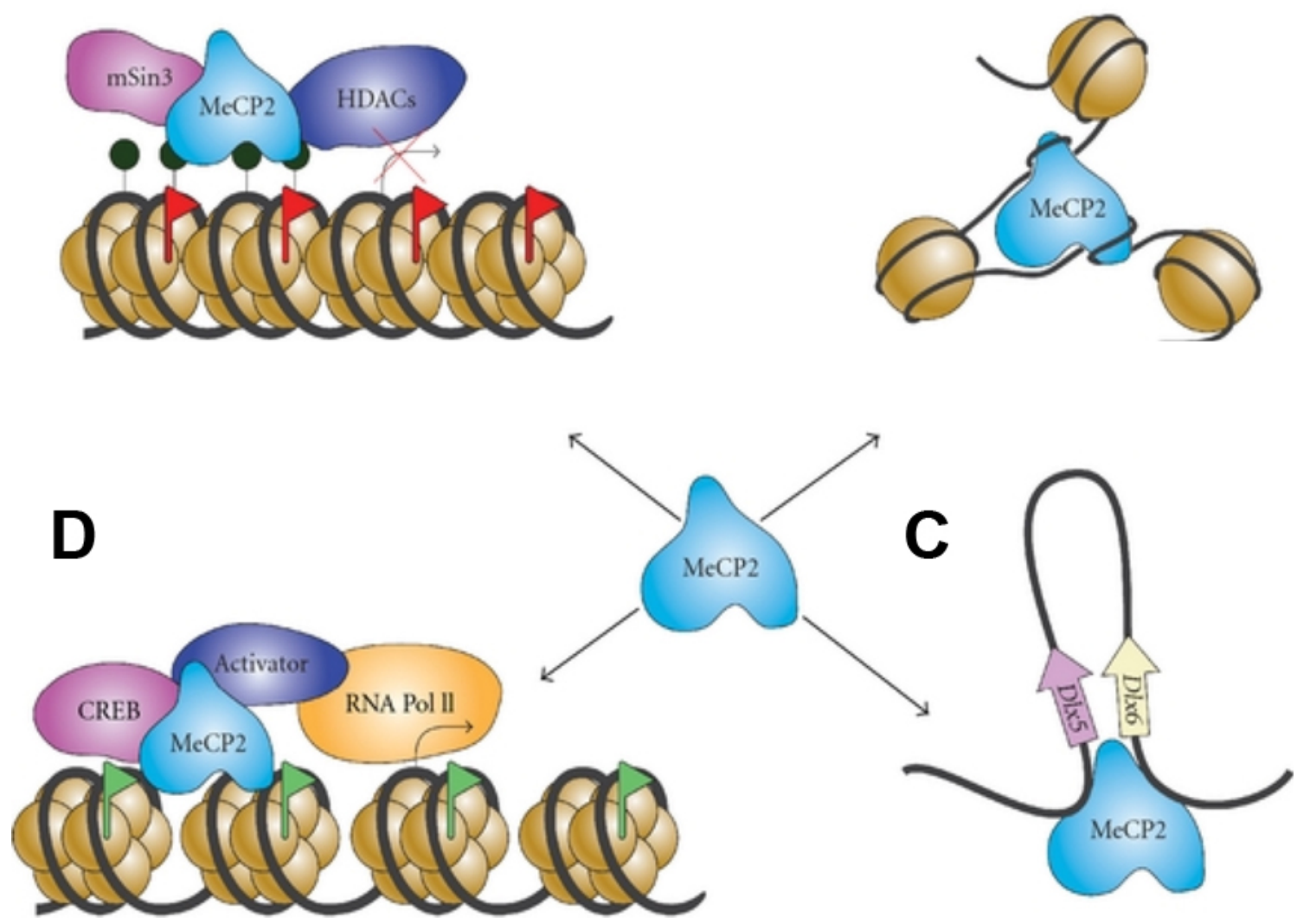

Figure 1.3 Functions of MeCP2 in chronological research order

(A) Repressor model: MeCP2 functions as a transcriptional repressor in the nucleus. (B) Structural model: MeCP2 condensates chromatin. (C) Loop and recruit model: MeCP2 causes a chromatin loop structure and recruits chromatin-remodeling factors. (D) Transcriptional activator model: MeCP2 interacts with the transcription factor CREB1; (Model adapted from Zachariah and Rastegar 2012). Abbreviations: Distal-less homeobox 5 protein (DIx5), distal-less homeobox 6 protein (DIx6), cAMP responsive element binding protein (CREB), RNA polymerase II (RNA Pol II), corepresor mSin3A $(\operatorname{Sin} 3 A)$, histone deacetylases (HDACs).

\subsubsection{The mouse model of Rett syndrome}

Since it is known that MECP2 mutations are responsible for RTT in humans, several mouse models have been developed, which lack the functional Mecp2 gene (Chen et al. 2001, Guy et al. 2001, Shahbazian et al. 2002). Depending on the sex, these mouse models are either termed $M e c p 2^{-1 y}$ or $M e c p 2^{-/ 4}$ mouse model (male or female mouse). The male mouse model $M e c p 2^{-1 y}$ displays highly similar symptoms to human RTT patients.

However, in contrast to male RTT patients (see 1.1 Rett syndrome), Mecp $2^{-1 y}$ mice live for a certain amount of days. In average they are viable until postnatal day 54 (P54) (Guy et al. 2001). 
The motor behavior of Mecp2 $2^{-/ y}$ mice (at P54) is very similar to that of humans. The Mecp2 $2^{-/ y}$ mice (at P54) show hind limp clasping corresponding to hand wringing stereotypes, unstableness in walking, tremor, unresponsiveness to external stimuli as well as hypoactivity (Guy et al. 2007). Even a discoordination of the oral system, including unbalanced clashing of teeth based on a jaw malfunction, has been identified in $M e c p 2^{-/ y}$ mice, and thus symptoms are similar to human bruxism (Guy et al 2001).

In comparison to wild type (wt) mice, $M e c p 2^{-/ y}$ mice are less active in exploring their littermates as well as their spatial environment (Samaco et al. 2013) and have a remarkably lower body weight and smaller body size (Guy et al. 2001). Fischer et al. (2009) revealed a lower amount of pyramidal neurons in the cortex area of Mecp2 $2^{-/ y}$ mice, resulting in less synaptic connections in the cerebrum (Chao et al. 2007). Finally, in comparison to hemizygous $M e c p 2^{+/-}$female mice, symptoms of $M e c p 2^{-/ y}$ mice occur earlier than the symptoms of hemizygous $M e c p 2^{+/}$female mice and are much more severe (Stearns et al. 2007). Hemizygous $M e c p 2^{+/-}$female mice are variable in their phenotype.

\subsubsection{Breathing impairment in $M e c p 2^{-/ y}$ mice}

Newborn Mecp $^{-/ y}$ mice, like newborn RTT patients, do not show any breathing disturbances (Guy et al. 2001, Viemari et al. 2005). First respiratory symptoms such as frequent apneas, apneusis (deep gasp like inhale followed by pause and then short, insufficient exhale), unsteady breathing cycle periods, and slow and erratic breathing are usually developed as soon as $M e c p 2^{-/ y}$ mice reach the age of P30 (Zanella et al. 2008, Ren et al. 2012). The corresponding age of humans is 1-1.5 years (Watson et al. 2006). The respiratory dysfunctions occur more frequently and persistently with increasing age (Ren et al. 2012). This development is very similar to the early development of human RTT patients (Katz et al. 2009).

Eupnoic breathing consists of three phases, i.e. inspiration, post-inspiration, and late expiration (Richter 1982). Mecp2-/y mice show prolonged post-inspiratory activity as well as shortened phases of inspiration and delayed expiration duration (Stettner et al. 2008). These breathing features cause breathing rhythm irregularities regarding frequency, amplitude (Ramirez et al. 2013) as well as apneas (Stettner et al. 2008). Arrhythmic breathing, long breathing arrests and tachypnea with approximately $20 \%$ 
higher breathing frequency are typical symptoms of $M e c p 2^{-/ y}$ mice (Ogier et al. 2007). In conclusion, periods of hyper- and hypoventilation alternate (Ramirez et al. 2013).

Different studies exist, which investigated the correlation between breathing disturbances and expression levels of genes, hormones, as well as hormone receptors in $M e c p 2^{-/ y}$ mice.

On gene level, for example, it was found that $M e c p 2^{-/ y}$ mice show lower Bdnf/BDNF expressions compared to wt mice, which lead to low levels of the growth factor ampakine. Inhibition of Bdnf in neurons induces breathing disturbances in wt mice (Mironov et al. 2009), whereas an increase of BDNF protein levels, as well as a medical treatment with ampakine, significantly improves respiration of $M e c p 2^{-/ y}$ mice (Ogier et al. 2007). Thus, researchers assume that low levels of ampakine contribute to the disturbed breathing phenotype.

At the hormone level, it was found that $M e c p 2^{-/ y}$ mice have lower levels of norepinephrines in comparison with wt mice, which modulate excitatory impulses between neurons (Viemari et al. 2005). Medical treatment with the neurotransmitter norepinephrine stabilizes the breathing rhythm of $M e c p 2^{-/ y}$ mice in vitro (Viemari et al. 2005) and in vivo (Ramirez et al. 2013). Ramirez et al. (2013) developed a model, which describes the breathing problems of $M e c p 2^{-/ y}$ mice as a 'vicious circle': Breathing problems arise from a synaptic imbalance caused by BDNF reduction. This imbalance then leads to oxidative stress, hyper-, and hypoventilation in $M e c p 2^{-/ y}$ mice. Finally, oxidative stress, hyper- and hypoventilation in $M e c p 2^{-/ y}$ mice result in modulatory disturbances in $M e c p 2^{-/ y}$ mice, represented by alterations of their norepinephrine and serotonin expressions (Ramirez et al. 2013). Changes in the expression levels of norepinephrine and serotonin deteriorate the breathing of $M e c p 2^{-/ y}$ mice further.

Finally, at the hormone receptor level it was found that $M e c p 2^{-/ y}$ mice show higher serotonin receptor $5 b\left(5-h t_{5 b}\right)$ levels in the ventral respiratory column (VRC) area (Vogelgesang, 2013). It has been found that this dysregulation directly leads to persistently low cAMP levels, due to the constitutive activity of 5 -ht $\mathrm{t}_{5 \mathrm{~b}}$ receptors (Vogelgesang, 2013). As a result, the central breathing rhythm of $M e c p 2^{-/ y}$ mice is disturbed. However, elevating cAMP levels pharmacologically leads to a significant improvement of breathing conditions (Vogelgesang 2013). 


\subsection{The respiratory network}

The main breathing function is to ensure the availability of oxygen in the organisms' blood circuit as well as the exhalation of carbon dioxide throughout the lungs. Various neuronal breathing models exist, indicating the scientific complexity of this physiological process (Richter et al. 1992, Balis et al. 1993, Richter et al. 1996, Matsugu et al. 1998, Smith et al. 2000). Different beliefs about function and number of respiratory neurons exist. This study follows the assumption that differing classes of neurons are involved in the breathing mechanism. They are classifiable into different functional as well as anatomical groups.

On functional level there are inspiratory, post-inspiratory, and expiratory neurons. Inspiratory, post-inspiratory, and expiratory neurons control the breathing rhythm and frequency. Thus, their activity levels differ depending on the specific breathing phase (Richter 1982, Ogilvie et al. 1992, Richter et al. 1992). On anatomical level a major group is known as the ventral respiratory group (VRG), which is part of the ventral respiratory column (Smith et al 1991). The ventral respiratory column is arranged as a longitudinal cell group alongside the compact part of the nucleus ambiguus (cNA) (Feldmann and McCrimmon 2003). Furthermore, it is divided into a rostral section, containing the Bötzinger and the pre-Bötzinger complex (pre-BötC) (Cotes et al 2006). The latter is considered to be essential for rhythmogenesis in mammals (Smith et al. 1991). 


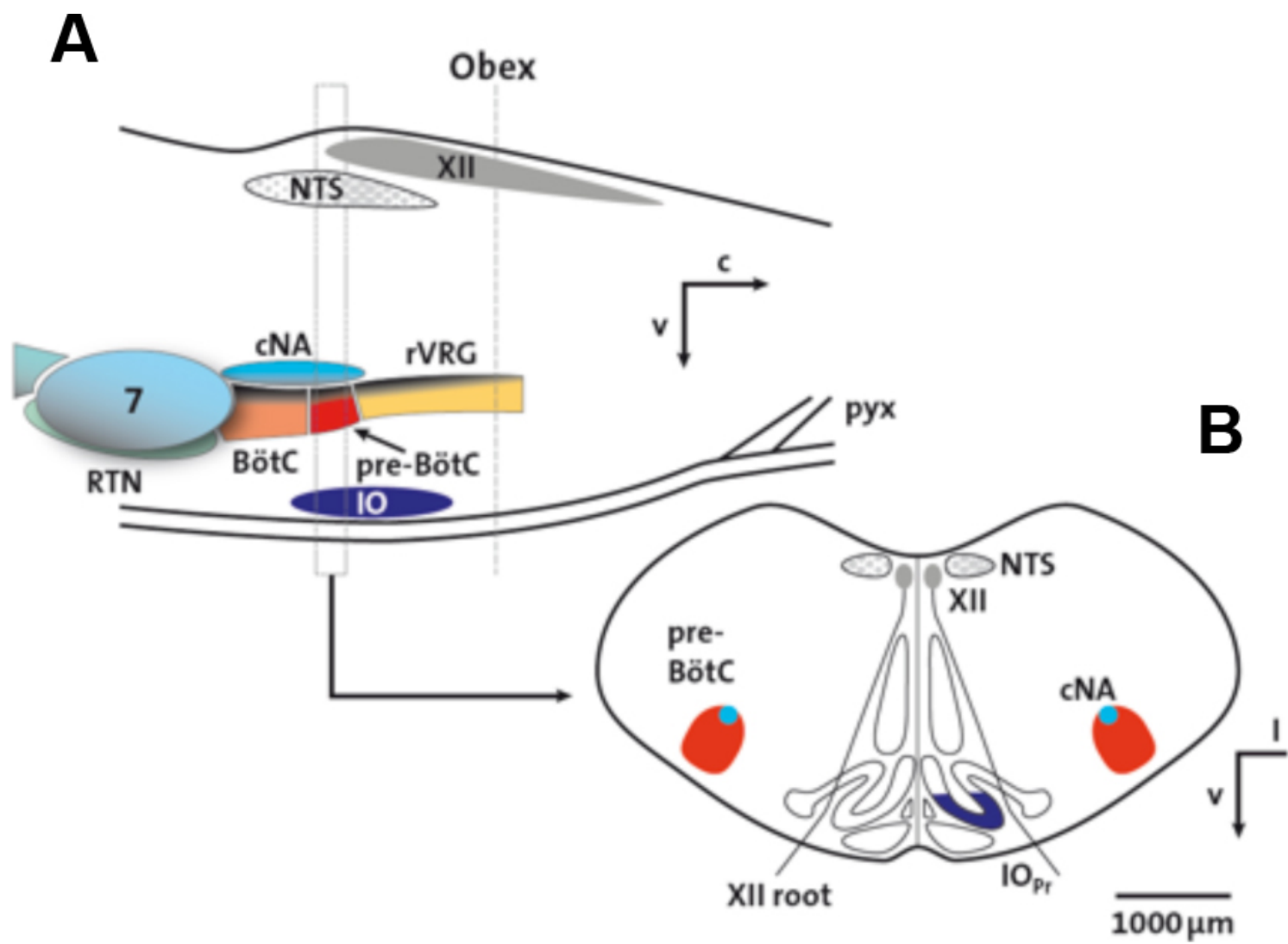

Figure 1.4 Schema of the localization of regions essential for respiratory rhythm generation

(A) Sagittal section: Column-like, bilaterally arranged breathing center, containing the respiratory network (colored). The sagittal section also contains the ventral respiratory group (rVRG), including the Bötzinger and pre-BötC in its rostral part as well as caudal part, which are important for generating the breathing-rhythm. This part of the illustration also shows the nucleus of the solitary tract, which is relevant for vagal reflexes. (B) Transversal section; (Model adapted from Vogelgesang 2013, 11). Abbreviations: Principal nucleus of the inferior olive $\left(\mathrm{IO}_{\mathrm{Pr}}\right)$, thalamic reticular nucleus (RTN), compact part of nucleus ambiguous (cNA), pre-BötC, Bötzinger complex (BötC), nucleus tractus solitarius (NTS), ventral respiratory group (VRG), hypoglossal nucleus (XII), pyramidal decussation (pyx), rostral (r), caudal (c), lateral (I).

The rhythm excitability within the respiratory network is adjusted synaptically by various neurochemicals, such as Bdnf, thyrotropin-releasing hormone (Trh), acetylcholine, adenosine-5'-triphosphate (ATP), dopamine, histamine, neurokinins, noradrenalin, opioids, and serotonin (Manzke 2013).

\subsection{Definition of Hypoxia}

Hypoxia describes the condition in which the tissue of the whole body or of distinct body regions is undersupplied with oxygen (Korner 1959). Hypoxia can, for example, be caused by vasoconstriction, respiratory or pulmonary lung disease (Morani et al. 2006), segmented oxygen supply of organs by means of cardiac insufficiency, thrombosis, or embolisms, reactions to mountain air, as well as anemia (Peyssonnaux et al. 2007). Common symptoms of individuals suffering under hypoxia are clouding of 
consciousness, fainting, seizures, shortness of breath, as well as muscle weakness (Chávez et al. 1995).

In hypoxic situations, the oxygen deficiency causes an inefficient anaerobic metabolism within neurons, which leads to an accumulation of lactate and a disruption of the membrane function. As a consequence, calcium enters postsynaptic cells in an unimpeded manner, which enables the production of free radicals. As a result mitochondria become dysfunctional and energy-generating processes are completely suppressed. In mild hypoxia certain neuronal functions become modified to ensure the survival of the neuron or to regulate a controlled apoptosis (Sprang and Brown 1987).

In the case of severe hypoxia, even morphological alterations, such as necrosis, shrinkage of brain parts, and selective neuron destruction can be observed (Shalak and Perlman 2004, Huang and Castillo 2008, Yue et al. 1997). Irreversible neuronal damage can take place after three minutes of hypoxia (Smith et al. 1984). During a decrease of oxygen the organism mainly concentrates on oxygen supply for the essential organs, particularly the CNS (Zauner et Muizelaar 1997). However, in the case of even further oxygen decrease this compensation mechanism fails. Consequently, the heart rate decelerates (Zwillich et al. 1982) and the blood pressure decreases (Courten-Myers et al. 1985).

Although hypoxia occurs systemically within the whole CNS, several brain regions are more susceptible for oxygen deficiency. This phenomenon is known as the 'selective vulnerability of the brain' (Johnston et al. 2001). In early life, neurons of evolutionary older brain regions, such as cerebellum (Cerv's-Navarro and Diemer 1991), or brain stem areas, such as the inferior olive and VRC region are more susceptible to hypoxic damages than neurons of evolutionary newer brain portions, such as neocortex (Panigrahy et al. 1995) However, neurons of evolutionary newer brain portions such as neocortex become more resistant with increasing age (Falini et al. 1998). Prone to damages caused by hypoxia are also parts of the brain with a high metabolic activity, such as the thalamus and cortex (Luigetti et al. 2012).

\subsubsection{Gene expression mediated adaption to hypoxia}

Hypoxia triggers a multifaceted genetic and cellular response, which is important in the maintenance of normal physiological functions. One gene, whose expression has been 
found to change under hypoxic conditions, is, erythropoietin (Epo), responsible for the capacity to carry oxygen through the blood system (Ebert and Bunn 1999). Epo is transcriptionally induced under hypoxic condition.

Other genes, whose expression has been found to change under hypoxic conditions are hypoxia inducible factors (Hifs). Hifs become degraded depending on their oxygen level. Hifs are the main regulators of Epo synthesis. Consequently, HIF proteins are generally defined as both the main oxygen sensors as well as modulators at the cellular and systemic level (Wenger 2002). HIF proteins regulate multiple genes (Warnecke et al. 2004, Chan and Giaccia 2007) which are related to hypoxia and/or are involved in improving oxygen transportation.

HIF proteins also affect the expression of genes involved in iron metabolism, such as transferrin (Rolfs et al. 1997). Moreover, they affect the expression of genes involved in the vascular regulation, such as the vascular endothelial growth factor (Damert et al. 1997). Finally, HIFs activate the transcription of genes responsible for anaerobic glycolysis, for example lactate dehydrogenase $A$ (Firth et al. 1995), as well as for general glycolysis due to a lower anaerobic energy efficiency, such as aldolase $A$ (Semenza et al. 1994).

\subsubsection{Hypoxia in Rett syndrome}

Although it is known that Rett mouse models exhibit impaired breathing, information about induced hypoxia is limited. Early indications of hypoxia in Rett mouse models have been described by Fischer et al. (2009). As expected, higher HIF-1a levels have been found in the Mecp2-/y mice' (P38-P60) brain areas cerebellum and neocortex compared to wt mice. 


\section{Aim of the study}

\section{Aim of the study}

This study aims to clarify whether breathing irregularities evoke systemic hypoxia throughout the brain of Mecp $2^{-/ y}$ mice. Hypoxia-mediated gene expressions as well as neuronal cell death in particular brain regions might explain further neurological symptoms, which are caused by breathing disturbances as well. Therefore, five brain areas have been analyzed: The (1) cerebellum, (2) cortex, (3) inferior olive, (4) hypothalamus as well as (5) VRC area. For all brain areas this study assumes that gene deregulations in these areas are interconnected to specific RTT symptoms.

$(1,2)$ The cerebellum and cortex area are associated with the movement control of mice (Clarke and O'Malley 1996, Fuster 2008). It is hypothesized that a dysregulation of gene expression in these brain areas might result in an impaired motor activity and unresponsiveness to external stimuli of $M e c p 2^{-/ y}$ mice.

(3) The inferior olive area is a further motor related region responsible for the coordination of $M e c p 2^{-/ y}$ mice and reports movement errors to the cerebellum area (Kawato and Gomi 1992). Thus, it is predicted that a deregulation of gene expression in this brain area is involved in an impaired motor activity in $M e c p 2^{-/ y}$ mice as well.

(4) The hypothalamus area is responsible for the metabolism functions of the body and controls vegetative functions, such as feeding, body temperature and emotional responses. It is thus assumed that gene alterations in the hypothalamic area might lead to the reduced bodyweight and size of $M e c p 2^{-/ y}$ mice.

(5) Finally, the VRC area regulates the breathing activity of mice. Because the VRC area is the brain's breathing center it is the most significant brain area to investigate. Therefore, it is hypothesized that respiratory disorders manifest themselves in abnormal gene expressions of neurons in particular (Feldmann and del Negro 2006). 


\section{Materials and methods}

\subsection{Materials}

\subsubsection{Instruments}

Table 3.3.1 Instruments

\begin{tabular}{|c|c|}
\hline Instruments & Manufacturer \\
\hline \multicolumn{2}{|l|}{ Autoclave } \\
\hline Systec 5075 ELV & Systec GmbH (Wettenberg) \\
\hline \multicolumn{2}{|l|}{ Blotting-Apparatus } \\
\hline iBlot & Invitrogen (Karlsruhe) \\
\hline \multicolumn{2}{|l|}{ Centrifuges } \\
\hline $5415 \mathrm{R}$ & Eppendorf (Hamburg) \\
\hline Centrifuge $5415 \mathrm{D}$ & Eppendorf (Hamburg) \\
\hline Mikro 200R & Hettich (Tuttlingen) \\
\hline \multicolumn{2}{|l|}{ Documentation } \\
\hline Alphalmager EC (western blot) & Alpha Innotec Corporation (San Leandro, USA) \\
\hline BioVision Video documentation (agarose gel) & Peqlab (Erlangen) \\
\hline \multicolumn{2}{|l|}{ Electrophoresis chambers } \\
\hline Horizontal, self-made (agarose gel) & by workshop UMG (Göttingen) \\
\hline Vertical, XCell Sure Lock & Invitrogen (Karlsruhe) \\
\hline \multicolumn{2}{|l|}{ Freezers } \\
\hline Comfort $\left(-20^{\circ} \mathrm{C}\right)$ & Liebherr (Biberach) \\
\hline U535 Innova $\left(-80^{\circ} \mathrm{C}\right)$ & New Brunswick Scientific (Edison, USA) \\
\hline \multicolumn{2}{|l|}{ Heat blocks } \\
\hline Thermofixer comfort & Eppendorf (Hamburg) \\
\hline Thermostat 5320 & Eppendorf (Hamburg) \\
\hline \multicolumn{2}{|l|}{ Microscopes } \\
\hline EM 900 & Zeiss (Göttingen) \\
\hline Meta-LSM 510 & Zeiss (Göttingen) \\
\hline \multicolumn{2}{|l|}{ Microtome } \\
\hline CM1510S & Leica Microsystems (Bensheim) \\
\hline \multicolumn{2}{|l|}{ pH meter } \\
\hline inoLab pH 720 & WTW (Weilheim) \\
\hline
\end{tabular}




\begin{tabular}{|c|c|}
\hline \multicolumn{2}{|l|}{ Photometer } \\
\hline NanoDrop 1000 Spectrophotometer & Thermo Fisher Scientific (Dreieich) \\
\hline \multicolumn{2}{|l|}{ Pipettes } \\
\hline 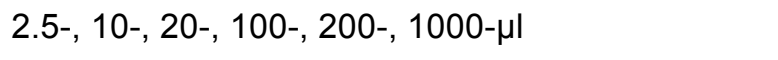 & Eppendorf (Hamburg) \\
\hline 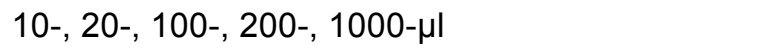 & Gilson (Limburg-Offheim) \\
\hline accu-jet & BRAND GmbH \& CoKG (Wertheim) \\
\hline Macro pipette controller & BRAND GmbH \& CoKG (Wertheim) \\
\hline Multipipette plus & Eppendorf (Hamburg) \\
\hline \multicolumn{2}{|l|}{ Power supplies } \\
\hline EV-231 & Biotec-Fischer (Reiskirchen) \\
\hline Power-Pac 3000 & BIO-RAD (München) \\
\hline \multicolumn{2}{|l|}{ Scales } \\
\hline 572 & Kern \& Sohn (Balingen-Frommern) \\
\hline Alt 100-5AM & Kern \& Sohn (Balingen-Frommern) \\
\hline \multicolumn{2}{|l|}{ Shakers/wheeled walker } \\
\hline Duomax 1030 & Heidolph Instruments (Schwabach) \\
\hline Genius 3 & IKA (Staufen) \\
\hline Roller Shaker "Assistant" RM5 & Glaswarenfabrik Hecht (Sondheim) \\
\hline Rotamax 120 & Heidolph Instruments (Schwabach) \\
\hline Titramax 1000 & Heidolph Instruments (Schwabach) \\
\hline \multicolumn{2}{|l|}{ Sterile bench } \\
\hline HeraSafe HSP & Heraeus (Berlin) \\
\hline \multicolumn{2}{|l|}{ Thermocyclers } \\
\hline C100 Thermal Cycler / CFX96 Real-Time System & BIO-RAD (München) \\
\hline Labcylers & SensoQuest (Göttingen) \\
\hline \multicolumn{2}{|l|}{ Western blot detection } \\
\hline Odyssey Sa Infrared Imaging System & Licor (Lincoln, USA) \\
\hline
\end{tabular}

\subsubsection{Consumables}

Table 3.2 Consumables

\begin{tabular}{|l|l|}
\hline Consumables & Manufacturer \\
\hline Aluminum foil & Roth (Karlsruhe) \\
\hline Centrifuge tubes (15-, 50-ml) & Greiner (Frickenhausen) \\
\hline Combitips (1-, 5-, 10-ml) & Eppendorf (Hamburg) \\
\hline
\end{tabular}




\begin{tabular}{|c|c|}
\hline Coverslips (24 x 50 mm) & Roth (Karlsruhe) \\
\hline Microscope slides (Superfrost ${ }^{\circledR}$ Plus) & Thermo Fisher Scientific (Dreieich) \\
\hline Microtiter plates (96-well) & Thermo Fisher Scientific (Dreieich) \\
\hline Nitrile gloves & Top glove (Duisburg) \\
\hline Parafilm & Pechiney (Chicago, USA) \\
\hline PCR plates (96-well) & BIO-RAD (München) \\
\hline 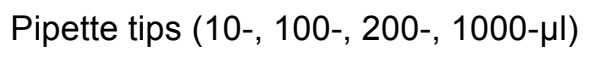 & nerbe plus (Winsen/Luhe) \\
\hline Reaction tubes (0.2-, 0.5-, 1.5-, 2-ml) & nerbe plus (Winsen/Luhe) \\
\hline Serological pipettes & Techno Plastic Products (Trasadingen, Suisse) \\
\hline Surgery (cannula, scalpels, syringes) & B. Braun (Melsungen) \\
\hline
\end{tabular}

\subsubsection{Chemicals and biochemical reagents}

Table 3.3 Chemicals and biochemical reagents

\begin{tabular}{|c|c|}
\hline Chemicals and biochemical reagents & Manufacturer \\
\hline Acetic acid $(100 \%)$ & Roth (Karlsruhe) \\
\hline Acetone & Roth (Karlsruhe) \\
\hline Agarose (for electrophoresis) & Peqlab (Erlangen) \\
\hline$\beta$-Mercaptoethanol & Merck (Darmstadt) \\
\hline BSA fraction $V$ & Roth (Karlsruhe) \\
\hline Calcium chloride & Roth (Karlsruhe) \\
\hline Chloroform & Roth (Karlsruhe) \\
\hline Dapi Fluoromount-G & Southern Biotech (Birmingham, USA) \\
\hline Desoxynucleosid-5'-triphosphate (100mM) & Invitrogen (Karlsruhe) \\
\hline ECL Western Blot kit & Amersham, GE Healthcare (München) \\
\hline Ethanol, absolute ultra pure & Roth (Karlsruhe) \\
\hline Ethanol, denatured (99\%) & $\mathrm{CVH}$ (Hannover) \\
\hline Ethidium bromide & Merck (Darmstadt) \\
\hline Ethylenediaminetetraacetic acid & Roth (Karlsruhe) \\
\hline Gene Ruler ${ }^{\circledR} 1$ kb-DNA-Ladder & Fermentas (St. Leon-Rot) \\
\hline Gene Ruler ${ }^{\circledR} 100$ bp-DNA-Ladder & Fermentas (St. Leon-Rot) \\
\hline Glucose & Roth (Karlsruhe) \\
\hline Glycerol & Sigma-Aldrich (Taufkirchen) \\
\hline Glycine & Roth (Karlsruhe) \\
\hline GlycoBlue & Ambion (Darmstadt) \\
\hline
\end{tabular}




\begin{tabular}{|c|c|}
\hline Hydrochloric acid (32\%) & Roth (Karlsruhe) \\
\hline IGEPAL CA-630 & Sigma-Aldrich (Taufkirchen) \\
\hline Isofluran & Baxter (Deerfield, USA) \\
\hline Isopropanol (ultra pure) & Roth (Karlsruhe) \\
\hline Magnesium chloride & Roth (Karlsruhe) \\
\hline Methanol & Roth (Karlsruhe) \\
\hline Nuclease-Free Water & Ambion (Darmstadt) \\
\hline Paraformaldehyde & Roth (Karlsruhe) \\
\hline Phenol & Sigma-Aldrich (Taufkirchen) \\
\hline Ponceau S & Sigma-Aldrich (Taufkirchen) \\
\hline Potassium chloride & Roth (Karlsruhe) \\
\hline Potassium dihydrogen phosphate & Roth (Karlsruhe) \\
\hline $\begin{array}{l}\text { Precision Plus Protein }{ }^{\mathrm{TM}} \text { Kaleidoscope }{ }^{\mathrm{TM}} \text { protein } \\
\text { standard }\end{array}$ & BIO-RAD (München) \\
\hline Protease inhibitor cocktail & Fermentas (St. Leon-Rot) \\
\hline Roti phenol & Roth (Karlsruhe) \\
\hline Saccharose & Roth (Karlsruhe) \\
\hline Sodium acetate & Roth (Karlsruhe) \\
\hline Sodium chloride & Roth (Karlsruhe) \\
\hline Sodium dodecyl sulfate & Roth (Karlsruhe) \\
\hline Sodium hydrogen carbonate & Roth (Karlsruhe) \\
\hline Sodium hydrogen phosphate & Roth (Karlsruhe) \\
\hline Sodium hydroxide & Roth (Karlsruhe) \\
\hline Tris & Roth (Karlsruhe) \\
\hline Triton X-100 & Sigma-Aldrich (Taufkirchen) \\
\hline Trizol & Invitrogen (Karlsruhe) \\
\hline Tween $^{\circledR} 20$ & Sigma-Aldrich (Taufkirchen) \\
\hline
\end{tabular}

\subsubsection{Kits}

Table 3.4 Kits

\begin{tabular}{|l|l|}
\hline Kits & Manufacturer \\
\hline D $_{\mathrm{C}}$ Protein Assay & BIO-RAD (München) \\
\hline iBlot Gel Transfer Stacks Nitrocellulose, Regular & Invitrogen (Karlsruhe) \\
\hline iScript & BIO-RAD (München) \\
\hline cDNA Synthesis & Invitrogen (Karlsruhe) \\
\hline
\end{tabular}




\begin{tabular}{|l|l|}
\hline Novex $4-20 \%$ Tris Glycine Gel & Qiagen (Hilden) \\
\hline QIAquick Gel Extraction & Qiagen (Hilden) \\
\hline QIAquick PCR Purification & Qiagen (Hilden) \\
\hline $\begin{array}{l}\text { RT }^{2} \text { Profiler PCR Array: Hypoxia Signaling } \\
\text { Pathway PCR Array \# PAXX-032Y }\end{array}$ & Qiagen (Hilden) \\
\hline
\end{tabular}

\subsubsection{Enzymes}

Table 3.5 Enzymes

\begin{tabular}{|l|l|l|}
\hline Name (conc.) & Company & Application (final conc.) \\
\hline Benzonase $(250 \mathrm{u} / \mu \mathrm{l})$ & Sigma-Aldrich & $1: 1000$ \\
\hline DNase $(10 \mathrm{u} / \mu \mathrm{l})$ & Fermentas & $1: 50$ \\
\hline Fast SYBR ${ }^{\circledR}$ Green $(2 \mathrm{x})$ & Applied Biosystems (Darmstadt) & $1 \mathrm{x}$ \\
\hline
\end{tabular}

\subsubsection{Primers for $q-P C R$}

Table 3.6 Primers for q-PCR

\begin{tabular}{|c|c|c|c|}
\hline Gene & Accession number & \multicolumn{2}{|c|}{ Sequence $\left(5^{\prime} \rightarrow 3^{\prime}\right)$} \\
\hline \multirow{2}{*}{ Casp1 } & \multirow{2}{*}{ NM_009807 } & Forward & AAACGCCATGGCTGACAAGATCC \\
\hline & & Reverse & GTCCCGTGCCTTGTCCATAGC \\
\hline \multirow{2}{*}{ Hif1a } & \multirow{2}{*}{ NM_010431.2 } & Forward & ACACACAGAAATGGCCCAGTGAGA \\
\hline & & Reverse & CCCGGCTTGTTAGGGTGCAC \\
\hline \multirow{2}{*}{ Mecp2 } & \multirow{2}{*}{ NM_010788.3 } & Forward & TCCTTGGACCCTAATGATTT \\
\hline & & Reverse & TTTCACСTGAACACСTTCTG \\
\hline \multirow{2}{*}{ Trh } & \multirow{2}{*}{ NM_009426.2 } & Forward & AGCCAGTTTGCACTCTTCGGC \\
\hline & & Reverse & AGGTCCCTGCATCTTGGAGTCTG \\
\hline \multirow{2}{*}{ Trhr1 } & \multirow{2}{*}{ NM_013696.2 } & Forward & CTATGGTTTGACAGCCTCGG \\
\hline & & Reverse & СТTTССССТСТTСАСТСТGТС \\
\hline \multirow{2}{*}{ Trhr2 } & \multirow{2}{*}{ NM_133202.2 } & Forward & СTCAATGTCCTCCAGGAAGC \\
\hline & & Reverse & ACCAGCACAGTTTCAGGAAG \\
\hline
\end{tabular}




\subsubsection{Primers for sequence verification}

Table 3.7 Primers for sequence verification

\begin{tabular}{|l|l|l|}
\hline \multirow{2}{*}{ Gene } & \multicolumn{2}{|l|}{ Sequence $\left(\mathbf{5}^{\prime} \rightarrow \mathbf{3}^{\prime}\right)$} \\
\hline \multirow{2}{*}{ Mecp2 wt (Genotyping) } & Forward & GACCCCTTGGGACTGAAGTT \\
\cline { 2 - 3 } & Reverse & CCACCCTCCAGTTTGGTTTA \\
\hline \multirow{2}{*}{ Mecp2 ko (Genotyping) } & Forward & CCATGCGATAAGCTTGATGA \\
\cline { 2 - 3 } & Reverse & ACCAGCACAGTTTCAGGAAG \\
\hline
\end{tabular}

\subsubsection{Primary antibodies}

Table 3.8 Primary antibodies

\begin{tabular}{|l|l|l|}
\hline Antibody (host) & Company & Final concentration \\
\hline Anti-GAPDH (mouse) & Biotrend (6C5) & $0.2 \mu \mathrm{g} / \mathrm{ml}$ \\
\hline Anti-HIF-1a (rabbit) & Abcam (ab2185) & $2 \mu \mathrm{g} / \mathrm{ml}$ \\
\hline
\end{tabular}

\subsubsection{Secondary antibodies}

Table 3.9 Secondary antibodies

\begin{tabular}{|l|l|l|}
\hline Antibody & Conjugate & Company \\
\hline Goat anti-mouse IgG & HRP & DAKO (Hamburg) \\
\hline Goat anti-rabbit IgG & HRP & DAKO (Hamburg) \\
\hline
\end{tabular}

\subsubsection{Mouse lines}

Table 3.10 Mouse lines

\begin{tabular}{|l|l|l|l|}
\hline Name & Genotype & Background & Source \\
\hline C57BL/6J & wt & & Jackson Laboratory \\
\hline 129P2(C)-Mecp2tm1-1Bird & Mecp2 ${ }^{-/ y}$ & C57BL/6J & Guy et al. 2001 \\
\hline
\end{tabular}




\subsubsection{Computer software}

Table 3.11 Computer software

\begin{tabular}{|l|l|l|}
\hline Program/web page & Company/address & Application \\
\hline Image J & National Institutes of Health & Analysis of color values \\
\hline $\mathrm{NCBI}$ & http://www.ncbi.nlm.nih.gov/ & $\begin{array}{l}\text { Basic information about } \\
\text { journals, genes etc. }\end{array}$ \\
\hline Office Excel & Microsoft (Unterschleißheim) & Data analysis \\
\hline Office Word & Microsoft (Unterschleißheim) & Writing \\
\hline Photoshop & Adobe Systems (München) & Image processing \\
\hline Primer-Blast & http://www.ncbi.nlm.nih.gov/tools/primer-blast/ & Primer generation \\
\hline Prism & GraphPad (La Jolla, USA) & Data analysis \\
\hline Serial cloner & SerialBasics (Internet, free) & Sequence comparison \\
\hline
\end{tabular}

\subsubsection{Universal buffers}

Buffers were prepared with double distilled water $\left(\mathrm{ddH}_{2} \mathrm{O}\right)$ of a deionization facility (Millipore) and afterwards autoclaved for $20 \mathrm{~min}$ at $121^{\circ} \mathrm{C}$ and $1.1 \mathrm{bar}$. X-fold stock solutions were diluted to 1-fold before using. Specific buffers are indicated in the method section.

Table 3.12 Universal buffers

\begin{tabular}{|l|l|}
\hline $10 x$ & $\mathrm{PBS}$ \\
\hline $1.5 \mathrm{M}$ & $\mathrm{NaCl}$ \\
\hline $38 \mathrm{mM}$ & $\mathrm{NaH}_{2} \mathrm{PO}_{4}$ \\
\hline $162 \mathrm{mM}$ & $\mathrm{Na}_{2} \mathrm{HPO}_{4}$ \\
\hline $\mathrm{pH}$ & 7.4 \\
\hline
\end{tabular}

\begin{tabular}{|l|l|}
\hline $10 \mathrm{x}$ & TBS \\
\hline $100 \mathrm{mM}$ & Tris \\
\hline $1.5 \mathrm{M}$ & $\mathrm{NaCl}$ \\
\hline $\mathrm{pH}$ & 7.6 \\
\hline
\end{tabular}

\begin{tabular}{|l|l|}
\hline & TBS-T \\
\hline $10 \%$ & $10 \times$ TBS \\
\hline $0.05 \%$ & Tween20 \\
\hline $\mathrm{pH}$ & 7.6 \\
\hline
\end{tabular}

\begin{tabular}{|l|l|}
\hline $50 \mathrm{x}$ & TAE \\
\hline $2 \mathrm{M}$ & Tris \\
\hline $5.7 \%$ & Acetic acid \\
\hline $50 \mathrm{mM}$ & EDTA \\
\hline $\mathrm{pH}$ & 8.0 \\
\hline
\end{tabular}

\begin{tabular}{|l|l|}
\hline $10 x$ & TBS \\
\hline $250 \mathrm{mM}$ & Tris \\
\hline $250 \mathrm{M}$ & $\mathrm{NaCl}$ \\
\hline $33 \mathrm{ml} \mathrm{150}$ & Tris \\
\hline $60 \mathrm{ml}$ & Glycerine \\
\hline
\end{tabular}




\subsection{Methods}

The following experimental procedures were performed according to the European Community and National Institutes of Health guidelines for the Care and Use of Laboratory Animals. Moreover, the Ethics Committee of the Georg-AugustUniversity, Göttingen, Germany, authorized the protocols.

\subsubsection{Animal work}

The following description involves the family background, generation, as well as handling of various mouse models, which were analyzed in the course of this study.

\subsubsection{Animal models}

As a model for Rett syndrome Mecp2 knockout mouse $\left(\mathrm{Mecp2}^{-1 y}\right)$, strain B6.129P2(C)-Mecp2tm1-1Bird (Guy et al. 2001), were used. The mice were obtained from Jackson Laboratory (Bar Harbor, ME, USA) and maintained on a C57BL/6J background. Mecp2 knockout males (Mecp2 ${ }^{-/ y}$ ) were generated by crossing hemizygous $\mathrm{Mecp}^{-/ 4}$ females with C57BL/6J wt males.

\subsubsection{Housing}

The ambient temperature and humidity of the mice cages was controlled and kept on constant level. A $12 \mathrm{~h}$ light-dark rhythm was set up. Finally, the animals were provided with pellet food and water ad libitum.

\subsubsection{Genotyping}

The DNA extracted from the mice' tail biopsies served as a template for a PCRbased genotyping. The specific sequences of the primer, which was applied to verify the genotype-specific DNA are listed in Table 3.3.1.

\subsubsection{Anesthesia}

The animals of postnatal stage P40 (40 days of postnatal age) were deeply anesthetized and made insensible to pain using volatile anesthetic Isofluran. After clear breathing deceleration and vibrissae motion termination, mice were decapitated as indicated in 3.2.2.4. 


\subsubsection{General brain preparation}

To avoid the destruction of relevant brain areas, after narcotization the decapitation of mice was done as cautious as possible. After fur and neck muscles were removed, the skull was opened by a longitudinal as well as transversal cut. Immediately afterwards, the brain was taken out and frozen on dry ice. For longtime storage brains were kept at $-80^{\circ} \mathrm{C}$.

\subsubsection{Specific preparation of several CNS areas}

As described above, the brain areas analyzed in the course of this study are cerebellum, cortex, hypothalamus, inferior olive, as well as VRC area. Figure 3.1 shows a sagittal section overview of a mouse brain with analyzed areas highlighted in red. In order to dissect areas of interest the brain was cut coronally into two approximately similar halves. Equally large sections from anterior and posterior cranial brain part provided slices from cortex (anterior) and cerebellum (posterior). Posterior wall of $3^{\text {rd }}$ ventricle served as reference point for identifying hypothalamic part. Coronal slices were made exactly at this position and triangles were cut out underneath $3^{\text {rd }}$ ventricle to remove hypothalamus. Using successive transversal sections from dorsal inferior olive (IO) identified by its typical loop structure, VRC was removed, which resides dorsolateral from principle nucleus of IO.

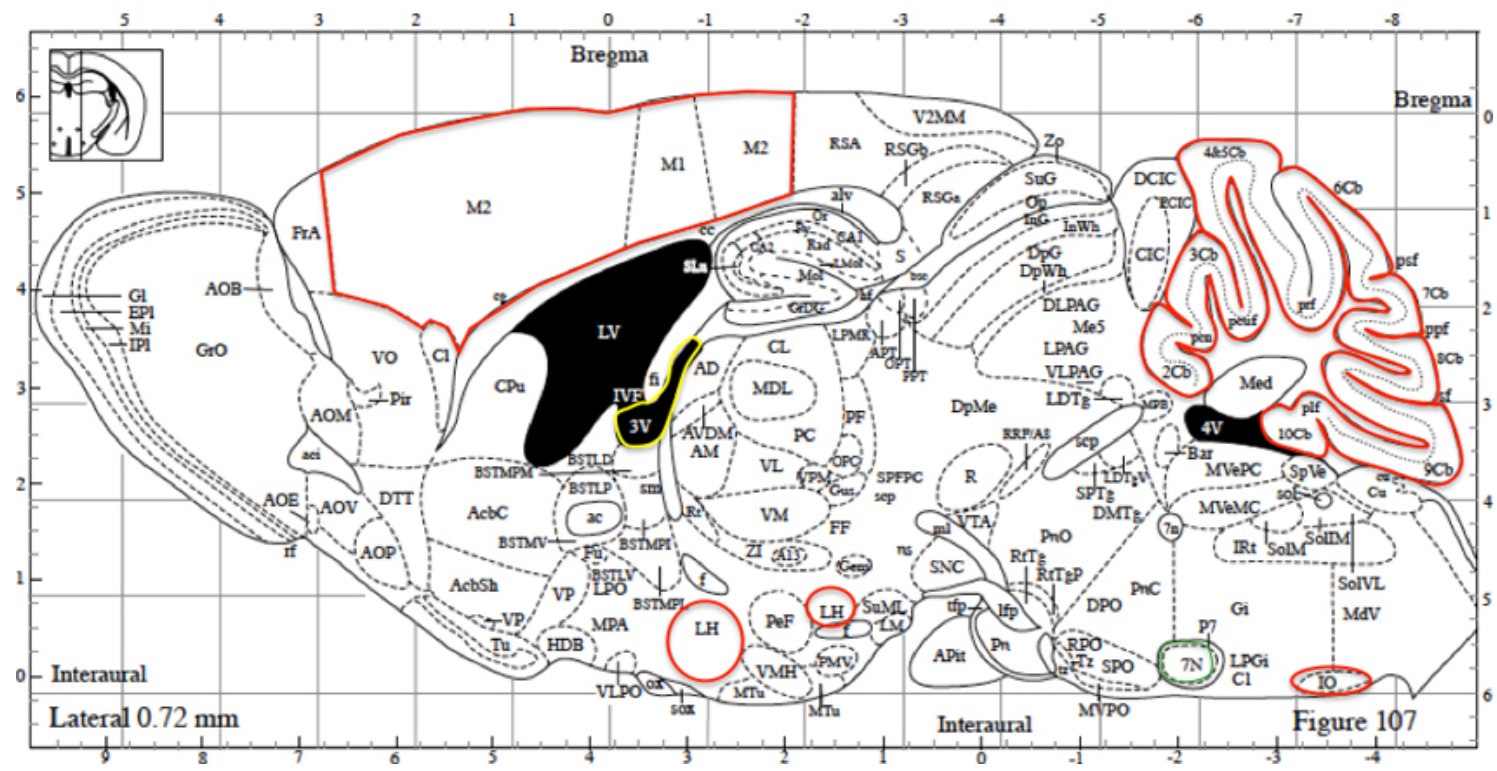

Figure 3.1 Schema of sagittal section of mouse brain with regions of interest

Abbreviations: different cerebellar lobules $(2-10 \mathrm{Cb}$, red), primary motor cortex (M1, red), secondary motor cortex (M2, red), lateral hypothalamic area ( $\mathrm{LH}$, red), $3^{\text {rd }}$ ventricle (3V, yellow), inferior olive (IO), facial nucleus (7N, green) (modified from Paxinos and Franklin 2001). 


\subsubsection{Molecular biology}

\subsubsection{Isolation of nucleic acids}

\subsection{DNA isolation from mice tails and PCR}

For genotyping, tail biopsies from mice at an age of circa P10 were taken. To extract DNA, the tails were incubated in $80 \mu \mathrm{l}$ of $25 \mathrm{mM} \mathrm{NaOH} / 0.2 \mathrm{mM}$ EDTA for $2.5 \mathrm{~h}$ at $99^{\circ} \mathrm{C}$ and shaken at $1,000 \mathrm{rpm} .0 .8 \mu \mathrm{l}$ of this solution served as a template in a subsequent PCR. The existing fragments were electrophoretically separated in a $1.5 \%$ agarose gel.

Table $3.1320 \mu$ l PCR master mix

\begin{tabular}{|c|c|}
\hline $15 \mu \mathrm{l}$ & $\mathrm{H}_{2} \mathrm{O}$ \\
\hline $2 \mu \mathrm{l}$ & $\mathrm{NH}_{4}$ reaction buffer $10 x$ \\
\hline $0.8 \mu \mathrm{l}$ & $\mathrm{MgCl}_{2} 50 \mathrm{mM}$ \\
\hline $0.8 \mu \mathrm{l}$ & Primer forward and reverse $(5 \mu \mathrm{M})$ (MeCP2 wt and ko - see table 3.7) \\
\hline $0.2 \mu \mathrm{l}$ & dNTP $25 \mathrm{mM}$ \\
\hline $0.4 \mu \mathrm{l}$ & Thermus aquaticus polymerase (Taq) (1 U/pl) (PANScript red, PAN) \\
\hline
\end{tabular}

Table 3.14 Cycling conditions

\begin{tabular}{|l|l|l|l|}
\hline Step & Cycle(s) & Duration & Temperature $\left({ }^{\circ} \mathbf{C}\right)$ \\
\hline Initial denaturation & 1 & $3 \mathrm{~min}$ & 95 \\
\hline Denaturation & & $30 \mathrm{~s}$ & 95 \\
\hline Annealing & $35-40$ & $30 \mathrm{~s}$ & $64-68$ \\
\hline Elongation & & $45 \mathrm{~s}-1 \mathrm{~min} 15 \mathrm{~s}$ & 72 \\
\hline Final elongation & 1 & $5 \mathrm{~min}$ & 72 \\
\hline Hold & 1 & infinite & 10 \\
\hline
\end{tabular}

\subsection{Isolation of whole RNA}

RNA isolation from mice brains was conducted by applying the Trizol ${ }^{\circledR}$ approach. All preparatory steps were carried out using RNAse-free materials to avoid a degradation as well as contamination of the RNA. 
Table 3.15 Solutions required isolating RNA

\begin{tabular}{|l|}
\hline Trizol $^{\circledR}$ \\
\hline Chloroform \\
\hline Isopropanol \\
\hline GlycoBlue $^{\mathrm{TM}}$ \\
\hline Ethanol (75\%) \\
\hline Nuclease-free water \\
\hline
\end{tabular}

The tissues were transferred to $900 \mu \mathrm{Trizo} \mathrm{I}^{\circledR}$ and homogenized with the aid of hand mortar. The tissues were then incubated and mixed gently for $5 \mathrm{~min}$ at RT. Following incubation, $200 \mu$ chloroform was added. The tubes with tissue content were shaken gently for $15 \mathrm{sec}$ by hand and incubated for further $5 \mathrm{~min}$ at RT. After a 20 min long centrifugation at $12.000 \mathrm{~g}$ and $4^{\circ} \mathrm{C}$, the transparent supernatant (ca. $600 \mu \mathrm{l}$ ) was transferred into new tubes and mixed with an equal amount of isopropanol as well as $1 \mu \mathrm{l}$ GlycoBlue $e^{\mathrm{TM}}$. The samples were incubated at $-28^{\circ} \mathrm{C}$ for $30 \mathrm{~min}$ and then centrifuged for $30 \mathrm{~min}$ at $17.900 \mathrm{~g}$ and $4^{\circ} \mathrm{C}$. Afterward, the supernatants were discarded. The remaining pellet was washed twice with $700 \mu \mathrm{l}$ of ethanol $(75 \%)$ and centrifuged for $5 \mathrm{~min}$ at $17.900 \mathrm{~g}$ and $4^{\circ} \mathrm{C}$. The supernatants were completely removed and the RNA pellet was dried in a heat block. Finally, the pellet was dissolved in $43.5 \mu$ of nuclease-free water. The DNAse digestion was carried out as described below.

Table 3.16 DNAse digestion mix (6.5 $\mu \mathrm{l})$

\begin{tabular}{|c|c|}
\hline $5 \mu \mathrm{l}$ & DNase I buffer 10x \\
\hline $1 \mu \mathrm{l}$ & DNAse I (10U/ul) \\
\hline $0.5 \mu \mathrm{l}$ & RNAseOut ${ }^{\mathrm{TM}}$ ribonuclease inhibitor $(40 \mathrm{U} / \mu \mathrm{l})$ \\
\hline
\end{tabular}

Table 3.3.17 Further chemicals

\begin{tabular}{|l|}
\hline Roti $^{\circledR}$ phenol \\
\hline Sodium acetate $3 \mathrm{M}, \mathrm{pH} 4.8$ \\
\hline Isopropanol \\
\hline GlycoBlue \\
\hline Ethanol $75 \%$ \\
\hline Nuclease-free water \\
\hline
\end{tabular}


After adding $6.5 \mu$ l of DNase I standard digestion mix, the RNA samples (50 $\mu$ in total) were vortexed, shortly centrifuged and incubated for $20 \mathrm{~min}$ at $37^{\circ} \mathrm{C}$. Then, the samples were filled up with RNAse-free water up to an end volume of $200 \mu \mathrm{l}$ and mixed with an equal amount of $\operatorname{Rot}^{\circledR}$ phenol. Roti ${ }^{\circledR}$ phenol contains phenol, chloroform, and isoamylalcohol (proportion $25: 24: 1$ ). The samples were gently mixed and centrifuged for $2 \mathrm{~min}$ at $12.000 \mathrm{~g}$ and RT. The hydrophilic upper phase with an approximate volume of $200 \mu \mathrm{l}$ was transferred into a new tube and mixed with 1:10 $(20 \mu \mathrm{l}) 3 \mathrm{M}$ sodium acetate $\mathrm{pH} 4.8$, an equal amount $(220 \mu \mathrm{l})$ of isopropanol, as well as $1 \mu \mathrm{l}$ of GlycoBlue ${ }^{\mathrm{TM}}$. The samples were gently mixed and incubated at $-28^{\circ} \mathrm{C}$ for $30 \mathrm{~min}$. Moreover, the samples were centrifuged for $30 \mathrm{~min}$ at $17.900 \mathrm{~g}$ and $4^{\circ} \mathrm{C}$. The supernatant was discarded and the pellets were washed with $500 \mu \mathrm{l}$ ethanol $75 \%$. Finally, after the ethanol was completely removed by drying the samples at $37^{\circ} \mathrm{C}$ for approx. $10 \mathrm{~min}$, the RNA pellets were dissolved in 25 $\mu \mathrm{l}$ nuclease-free water.

\subsubsection{Spectrophotometric determination of nucleic acid concentration}

The RNA quantity was calculated by a spectrophotometric measurement of wavelength absorbance at $260 \mathrm{~nm}$ using NanoDrop 1000. An optical density of 1.0 equates to a concentration of $40 \mu \mathrm{g} / \mathrm{ml}$ single-stranded RNA and thus $50 \mu \mathrm{g} / \mathrm{ml}$ double-stranded DNA. The RNA quality was assessed by measuring the absorbance at a wavelength of $280 \mathrm{~nm}$. To ensure proper RNA integrity, the RNA was mixed up with 6x DNA loading buffer, loaded onto agarose gel, which was placed in $1 x$ TAE buffer. The RNA probes were separated by a voltage of $5 \mathrm{~V} / \mathrm{cm}$ (electrode distance). The results were visualized by using UV-light as well as a BIO$V_{I S I O N}{ }^{T M}$ fluorescence documentation system. If the integrity of RNA was sufficient, the RNA showed two different bands, which represented 18S (Svedberg unit) ribosomal RNA (rRNA) and 28S rRNA. 28S rRNA appeared in the lower band, which is twice as dark as the band of 18S rRNA.

\subsubsection{3 cDNA synthesis from RNA}

The extracted RNA samples were transcribed into complementary single strand DNA (cDNA) via the Moloney Murine Leukemia Virus (MMLV) reverse transcriptase, which can also be described as an RNA-dependent DNA polymerase. To do so, 
iScript $^{\mathrm{TM}}$ cDNA synthesis kit was used in accordance to the procedures, prescribed by the manufacturer.

Table 3.18 DNA synthesis master mix $(20 \mu \mathrm{l})$

\begin{tabular}{|l|l|}
\hline $4 \mu \mathrm{l}$ & iScript Reaction Mix 5x \\
\hline $1 \mu \mathrm{l}$ & iScript reverse transcriptase \\
\hline $\mathrm{x} \mu \mathrm{l}$ & $\mathrm{RNA}(500 \mathrm{ng})$ \\
\hline $15-\mathrm{x} \mu \mathrm{l}$ & $\mathrm{H}_{2} \mathrm{O}$ (nuclease-free) \\
\hline
\end{tabular}

$0.5 \mu \mathrm{g}$ RNA was transcribed per reaction using a thermocycler and the following cycling conditions:

Table 3.19 Cycling conditions for cDNA synthesis

\begin{tabular}{|l|l|l|l|}
\hline Step & Cycle(s) & Duration $($ min) & Temperature $\left({ }^{\circ} \mathbf{C}\right)$ \\
\hline Activation & 1 & 4 & 25 \\
\hline Elongation & 1 & 30 & 42 \\
\hline Denaturation & 1 & 5 & 85 \\
\hline Hold & 1 & Infinite & 10 \\
\hline
\end{tabular}

\subsubsection{Quantitative real-time PCR (qRT-PCR)}

First, the C100 Thermal Cycler denaturized and melted the DNA into single-strands at $95{ }^{\circ} \mathrm{C}$. In a second phase, the primers were hybridized at $64-68{ }^{\circ} \mathrm{C}$. In a third phase, the elongation phase, the DNA was extended at $72{ }^{\circ} \mathrm{C}$. After every single elongation cycle, the fluorescent molecule SYBR-Green intercalates with the freshly synthesized double-stranded DNA. The initial cDNA amount is determined by comparing the threshold value of cDNA with the threshold value of the standard curve. To determine the melting curves, the temperature was stepwise increased by $0.5{ }^{\circ} \mathrm{C}$ after every other cycle until $95^{\circ} \mathrm{C}$ was reached. Reference housekeeping genes were tested as duplicates, whereas the genes of interest were analyzed as triplicates. Finally, the CFX96 ${ }^{\mathrm{TM}}$ Real-time System determined the mRNA quantification. The gene expression was calculated using the $2^{-\Delta \Delta C t}$ method (Pfaffl 2001). 
Table 3.20 qRT-PCR master mix (10 $\mu \mathrm{l})$

\begin{tabular}{|l|l|}
\hline $5 \mu \mathrm{l}$ & Fast SBYR ${ }^{\circledR}$ Green Master Mix 2x \\
\hline $3.85 \mu \mathrm{l}$ & $\mathrm{H}_{2} \mathrm{O}$ \\
\hline $0.2 \mu \mathrm{l}$ & Forward primer, 200 nM \\
\hline $0.2 \mu \mathrm{l}$ & Reverse primer, 200 nM \\
\hline $0.75 \mu \mathrm{l}$ & cDNA \\
\hline
\end{tabular}

Table 3.21 Cycling conditions for qRT-PCR

\begin{tabular}{|l|l|l|l|}
\hline Step & Cycle(s) & Duration & Temperature $\left({ }^{\circ} \mathbf{C}\right)$ \\
\hline Enzyme activation & 1 & $3 \mathrm{~min}$ & 95 \\
\hline Denaturation & & $30 \mathrm{~s}$ & 95 \\
\hline Annealing/ elongation & 40 & $30 \mathrm{~s}$ & $64-68$ \\
\hline Detection & \multicolumn{2}{|l}{} \\
\hline Melting curve & 1 & $10 \mathrm{~s}$ & 95 \\
\cline { 3 - 5 } & & in $0.5^{\circ} \mathrm{C}$ steps & $65-90$ \\
\hline
\end{tabular}

\subsubsection{5 $R T^{2}$ Profiler PCR Array: Hypoxia Signaling Pathway}

For the gene expression profiling of hypoxia related genes, an $R T^{2}$ Profiler $P C R$ Array analysis was performed in accordance with the manufacture's instructions. The same RNA amounts of 5 biological replicates of each wt and MeCP2 deficient mice were pooled to a concentration of $100 \mathrm{ng} / \mu \mathrm{l}$ in a volume of $10 \mu \mathrm{l}$ and transcribed into cDNA by adding the same amount of reverse-transcription mix (provided by the kit) to it. Then, the cDNAs were mixed up with $90 \mu$ l of RNase-free water and a Real-time PCR mix was prepared as described in Table 3.22. To perform the $R T^{2}$ Profiler PCR Array, $25 \mu$ of RT-PCR master mix was added to each of the 96 wells and a RT-PCR was run (see Table 3.22). To assess the gene expression a supplied data analysis software was used.

Table 3.22 RT-PCR master mix (2700 $\mu$ l)

\begin{tabular}{|l|l|}
\hline $1350 \mu \mathrm{l}$ & $\mathrm{RT}^{2}$ SBYR Green Mastermix \\
\hline $102 \mu \mathrm{l}$ & CDNA \\
\hline $1248 \mu \mathrm{l}$ & RNase-free water \\
\hline
\end{tabular}


Materials and methods

Table 3.23 Cycling conditions for RT-PCR

\begin{tabular}{|l|l|l|l|}
\hline Step & Cycle(s) & Duration & Temperature $\left({ }^{\circ} \mathbf{C}\right)$ \\
\hline Activation of HotStart DNA & 1 & $10 \mathrm{~min}$ & 95 \\
\hline Taq Polymerase & 40 & $15 \mathrm{~s}$ & 95 \\
\hline Fluorescence data collection & & $1 \mathrm{~min}$ & 60 \\
\hline
\end{tabular}

\subsubsection{Protein biochemistry}

\subsubsection{Total protein isolation from cerebellum and cortex}

Tissue from freshly frozen brains was dissolved in $200 \mu$ lysis buffer (see Table 3.24). Benzonase ${ }^{\circledR}$ is a nuclease, which degrades various kinds of nucleic acids. The mixture was pestled using a hand mortar and then incubated on ice for $30 \mathrm{~min}$. The mixture was occasionally vortexed. Samples were taken for a protein concentration analysis as described in the following section.

Table 3.24 SDS Lysis buffer

\begin{tabular}{|l|l|}
\hline $50 \mathrm{mM}$ & Tris \\
\hline $150 \mathrm{mM}$ & $\mathrm{NaCl}$ \\
\hline $2 \mathrm{mM}$ & EDTA \\
\hline $2 \%$ & SDS \\
\hline $1 \%$ & IGEPAL CA-630 \\
\hline $5 \mathrm{u}$ & Benzonase $^{\circledR}$ \\
\hline $1 \%$ & Protease inhibitor cocktail $^{\circ}$ \\
\hline $\mathrm{pH}$ & 6.8 \\
\hline
\end{tabular}

\subsubsection{Protein concentration analysis}

The protein concentration of the cerebellum and cortex samples was determined using a $D_{C}$ Protein Assay, which is based on the protein determination approach of Lowry et al. (1951). First, a standard curve was arranged, consisting of bovine serum albumin (BSA) concentrations from $200-1,500 \mu \mathrm{g} / \mathrm{ml} .5 \mu \mathrm{l}$ of a protein sample were mixed up with $25 \mu \mathrm{l}$ Reagent A' (mixture of $20 \mu \mathrm{l}$ reagent S with $1 \mathrm{ml}$ buffer $\mathrm{A}$ ). Then, $200 \mu$ of buffer $B$ were added. After gently mixing and incubating the liquid for $5 \mathrm{~min}$ at RT, the wavelength at $690 \mathrm{~nm}$ was measured using Nanodrop1000. The protein concentrations were calculated by means of the standard curve. Finally, the samples were adjusted to a protein concentration of $2 \mu \mathrm{g} / \mu \mathrm{l}$, mixed with $5 \mathrm{x}$ 
Laemmli buffer (see Table 3.25) and heated up for $10 \mathrm{~min}$ to $85^{\circ} \mathrm{C}$. For long term storage sample were kept at $-20^{\circ} \mathrm{C}$.

Table 3.25 Laemmli buffer (x5)

\begin{tabular}{|l|l|}
\hline $250 \mathrm{mM}$ & Tris \\
\hline $7 \%$ & SDS \\
\hline $10 \mathrm{mM}$ & EDTA \\
\hline $50 \%$ & Glycerine \\
\hline $50 \mathrm{mM}$ & EDTA \\
\hline $7 \%$ & $\beta$-mercaptoethanol (fresh) \\
\hline $\mathrm{pH}$ & 6.8 \\
\hline
\end{tabular}

\subsubsection{Sodium dodecyl sulfate polyacrylamide gel electrophoresis}

In order to separate the proteins, $30 \mu \mathrm{l}$ (60 $\mathrm{gg}$ total protein) of the protein samples and $10 \mu \mathrm{l}$ of the size marker Precision Plus Protein ${ }^{\mathrm{TM}}$ Kaleidoscope $^{\mathrm{TM}}$ were loaded onto a 4-20 \% SDS-polyacrylamide gel Novex ${ }^{\circledR}$. The gel was then transferred into a SDS-containing tris-glycine buffer system (see Table 3.26). For protein separation a voltage of $125 \mathrm{~V}$ was applied for $3 \mathrm{~h}$. Sodium dodecyl sulfate polyacrylamide gel electrophoresis (SDS-PAGE) was run.

Table 3.26 Running buffer (x10)

\begin{tabular}{|l|l|}
\hline $250 \mathrm{mM}$ & Tris \\
\hline $2 \mathrm{M}$ & Glycine \\
\hline $10 \%$ & SDS \\
\hline $\mathrm{pH}$ & 8.3 \\
\hline
\end{tabular}

\subsubsection{Protein detection by western blot}

To make specific proteins visible, the proteins were transferred from the gel to a nitrocellulose membrane, using the $i B l o t^{\circledR}-7-$ minute Blotting System, which includes iBlot $^{\circledR} \mathrm{Gel}$ Transfer Stacks. Firstly, the bottom stack, which contains a $0.2 \mu \mathrm{m}$ thick nitrocellulose membrane, was placed in the blotting device. Then, the gel, which was washed in $\mathrm{ddH}_{2} \mathrm{O}$, was put onto the membrane and covered with a $\mathrm{ddH}_{2} \mathrm{O}$ soaked filter paper. The cathode stack was placed on top of the soaked filter paper. 
Finally, the $i B l o t^{\circledR}$ Disposable Sponge was inserted and the device was turned on at a voltage of $23 \mathrm{~V}$ for $7 \mathrm{~min}$.

Afterwards, the protein transfer was verified by means of a reversible protein staining using a "Ponceau S" solution. Ponceau $S$ was washed out thoroughly three times using TBS-T for 5 min each. For the protein-specific antibody staining, the membrane was blocked with 5\% BSA/TBS-T for $1 \mathrm{~h}$ at RT. After the washing, the membrane was exposed to primary antibody rabbit anti-HIF-1a, which was diluted in a concentration of $2 \mu \mathrm{g} / \mathrm{ml}$ in $2.5 \%$ BSA/TBS-T for $3 \mathrm{~h}$ at RT. The primary antibody mouse anti-GAPDH, which served as a loading control, was applied simultaneously in a concentration of $0.2 \mu \mathrm{g} / \mathrm{ml}$. After an intensive washing, the membranes were mixed with $0.02 \mu \mathrm{g} / \mathrm{ml}$ secondary goat anti-rabbit and goat antimouse antibodies and incubated in 2.5\% BSA/TBS-T for $2 \mathrm{~h}$ at RT. These antibodies bind to domains in the Fc-part of the primary antibody specifically. During this procedure, after washing and drying the membrane, conjugated fluorophores with a specific wavelength $(680 \mathrm{~nm}$ and $800 \mathrm{~nm}$ ) were detected, using the Odyssey CLx scanner. 


\section{Results}

This section gives an overview as to whether breathing disturbances in $M e c p 2^{-1 y}$ mice lead to systemic hypoxia. Unless otherwise stated experiments were performed at postnatal stage P40 when the respiratory phenotype is fully developed.

\subsection{Analysis of general hypoxia-mediated mRNA expression in the brain}

In order to analyze general hypoxia-mediated mRNA expression, a customized $R T^{2}$ Profiler PCR Array was performed comprising 84 genes associated with hypoxia. Total RNA from the VRC area of $5 \mathrm{Mecp}^{-/ y}$ mice were pooled and compared with wt mice. The VRC area of the brain was chosen for these experiments for the following 2 reasons:

Firstly, the VRC area contains respiratory neurons interacting with each other and is responsible for the initiation of breathing. It is assumed that hypoxia, which is caused by irregular breathing rhythm, becomes visible in this respiration modulating brain area first. Secondly, the VRC was chosen for analysis, because it is relatively unsusceptible to gene deregulation in general, compared to other brain regions. Additionally, it was found that the VRC area of adult brains is, to some degree, resistant to damages caused by hypoxia in particular (1.3 Definition of Hypoxia) (Johnston et al. 2001, Falini et al. 1998). Both of the above reasons allow one to draw conclusions whether severe hypoxia based on respiratory irregularities in the brain of $M e c p 2^{-/ y}$ mice compared to wt mice can be found.

By running the $R T^{2}$ Profiler PCR Array it was discovered that except for Casp1 all other genes investigated did not show any significant changes in their expression levels when comparing wt to $M e c p 2^{-1 y}$ mice. Casp1 was found to be up-regulated in $M{ }^{-1 y}$ mice by 2.8-fold compared to wt mice. On the basis of this result, Casp1 was analyzed in more detail within further 4 brain areas (4.2.1 Analysis of Casp1 expression). In addition, the expression of 8 selected neuronal key genes that have been shown to be massively affected by hypoxia were analyzed within the VRC area. Table 4.1 introduces each neuronal key gene briefly and provides examples of studies that support its relevance for hypoxia. 
Table 4.1 Hypoxia related genes

\begin{tabular}{|c|c|}
\hline $\begin{array}{l}\text { Adrenomedullin (Adm) } \\
\text { Peptide }\end{array}$ & $\begin{array}{l}\text { - Trollmann et al. (2010) included this gene in } \\
\text { analyses of microarray and demonstrated } \\
\text { elevated } A d m \text { levels in mouse brain by using } \\
\text { high-density oligonucleotide microarrays, RT- } \\
\text { PCR and immunohistochemistry after hypoxia. } \\
\text { Halterman et al. (2010) used the microarray } \\
\text { method and found elevated } A d m \text { levels in in } \\
\text { vitro cortical culture model after hypoxia as } \\
\text { well. } \\
\text { Kaur et al. (2012) found out elevated } A d m \\
\text { levels analyzing the cerebellum area of hypoxic } \\
\text { neonatal rats. }\end{array}$ \\
\hline $\begin{array}{l}\text { Glucose phosphate isomerase } 1 \text { (Gpi1) } \\
\text { Glycolysis enzyme }\end{array}$ & $\begin{array}{l}\text { - Jin et al. (2002) found that Gpi1 is induced by } \\
\text { hypoxia after examining cerebral cortical } \\
\text { neurons of mice utilizing cDNA microarray } \\
\text { gene expression profiling, } \\
\text { - Ishikawa et al. (2010) showed up-regulated } \\
\text { Gpi1 expression levels in hypoxic murine } \\
\text { retinas utilizing gene microarrays, qRT-PCR } \\
\text { and multiplex ELISA. } \\
\text { Halterman et al. (2010) demonstrated induction } \\
\text { of Gpi1 in mice brain after hypoxia in in vitro } \\
\text { cortical culture model by use of microarray. }\end{array}$ \\
\hline $\begin{array}{l}\text { Hexokinase } 2 \text { (Hk2) } \\
\text { Hexoses phosphorylating enzyme }\end{array}$ & $\begin{array}{l}\text { - Trollmann et al. (2010) included this gene in } \\
\text { analyses of microarray and demonstrated } \\
\text { elevated Hk2 levels in mouse brain by using } \\
\text { high-density oligonucleotide microarrays, RT- } \\
\text { PCR and immunohistochemistry after hypoxia } \\
\text { as well. } \\
\text { Jolly et al. (2011) found higher Hk2 expression } \\
\text { levels after hypoxia by running RT-PCR within } \\
\text { neurons and astrocytes. } \\
\text { Halterman et al. (2010) showed induction of } \\
\text { Hk2 after hypoxia in in vitro cortical culture } \\
\text { model in mice by use of microarray. }\end{array}$ \\
\hline $\begin{array}{l}\text { Insulin like growth factor binding protein } 3 \\
\text { (Igfbp3) } \\
\text { Binding of differentiation factors }\end{array}$ & $\begin{array}{l}\text { - Ragel et al. (2007) found elevated lgfbp3 levels } \\
\text { in malignant glioma cell line after hypoxia by } \\
\text { use of cDNA microarray chip. } \\
\text { Beilharz et al. (1998) found elevated lgfbp3 } \\
\text { levels after hypoxia in the hippocampus area of } \\
\text { rats by in situ hybridization, } \\
\text { immunohistochemistry, Northern blot analysis, } \\
\text { RNAse protection assay and RT-PCR. } \\
\text { Lee et al. (1999) found elevated Igfbp3 levels } \\
\text { after hypoxic-ischemic injury by using in situ } \\
\text { hybridization and histochemistry within brain } \\
\text { areas thalamus, hippocampus and amygdaloid. }\end{array}$ \\
\hline $\begin{array}{l}\text { Interleukin } 1 \text { (II-1) } \\
\text { Cytokine }\end{array}$ & $\begin{array}{l}\text { - Szaflarski et al. (1995) detected elevated IL-1 } \\
\text { levels in brain areas cortex and hippocampus } \\
\text { after hypoxia in rats by use of RT-PCR and } \\
\text { southern blot. } \\
\text { Savard et al. (2013) showed increased IL-1 } \\
\text { levels in cortex after hypoxia in rats by applying } \\
\text { in situ hybridization and ELISA. } \\
\text { Kaur et al. (2012) showed elevated IL-1 levels } \\
\text { in cerebellar purkinje neurons of neonatal rats } \\
\text { subjected to hypoxia. }\end{array}$ \\
\hline
\end{tabular}




\begin{tabular}{|c|c|}
\hline $\begin{array}{l}\text { Solute carrier family } 2 A 3(\text { SIc2a3) = Glut } 3 \\
\text { Glucose transporter }\end{array}$ & $\begin{array}{l}\text { Ragel et al. (2007) found elevated S/c2a3 } \\
\text { levels in malignant glioma cell line after } \\
\text { hypoxia by use of cDNA microarray chip. } \\
\text { - Lusardi et al. (2009) analyzed mouse cortex by } \\
\text { use of RT-PCR and found elevated S/c2a3 } \\
\text { levels after hypoxia. } \\
\text { Vanucci et al. (1996) found higher G/ut3 } \\
\text { expression levels in rat brain after hypoxia } \\
\text { using western blot method. }\end{array}$ \\
\hline $\begin{array}{l}\text { Transforming growth factor } 1 \text { (Tgf-1) } \\
\text { Neurotrophic factor }\end{array}$ & $\begin{array}{l}\text { Klempt et al. (1992) found elevated expression } \\
\text { levels of Tgf-1 in the rat brain areas cortex, } \\
\text { thalamus, and hippocampus utilizing in situ } \\
\text { hybridization. } \\
\text { Kawahara et al. (2004) showed elevated Tgf-1 } \\
\text { expression levels within hippocampal regions } \\
\text { of rats after ischemia utilizing an } \\
\text { oligonucleotide-based DNA microarray. } \\
\text { - Hughes et al. (1999) depicted elevated Tgf } \\
\text { levels within glia after neuronal injury in rats. }\end{array}$ \\
\hline $\begin{array}{l}\text { Vascular endothelial growth factor (Vegf) } \\
\text { Signal protein }\end{array}$ & $\begin{array}{l}\text { - Trollmann et al. (2010) analyzed brain tissue } \\
\text { by use of high-density oligonucleotide } \\
\text { microarrays, RT-PCR and } \\
\text { immunohistochemistry in developing mouse } \\
\text { brains and found up-regulated Vegf expression } \\
\text { levels. } \\
\text { - Kaur et al. (2012) found out elevated Vegf } \\
\text { expression levels analyzing the cerebellum } \\
\text { area of neonatal rats. } \\
\text { - Stone et al. (1995) demonstrated hypoxia } \\
\text { induced up-regulated Vegf levels in the retina } \\
\text { of cats and rats by using in situ hybridization } \\
\text { techniques. }\end{array}$ \\
\hline
\end{tabular}

In order to compare mRNA expression of these hypoxia-indicating genes within the VRC at P40, qRT-PCR experiments were performed (see figure 4.1). 
$A d m$

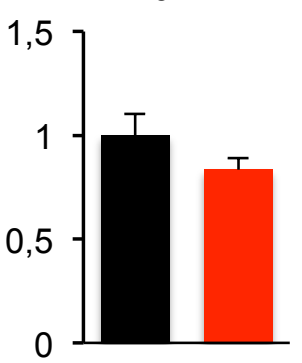

II-1

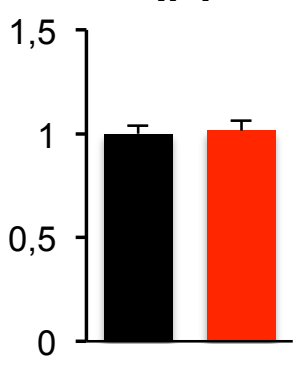

Gpi1

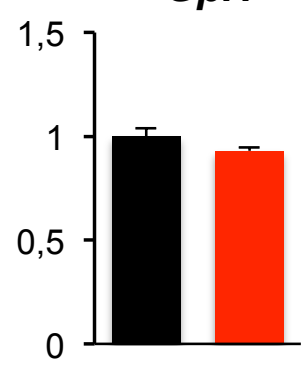

Slc2a3

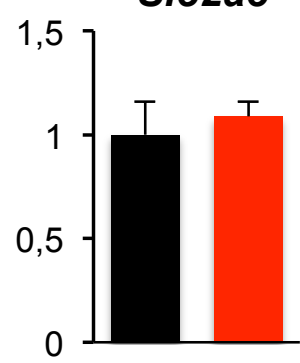

Hk2

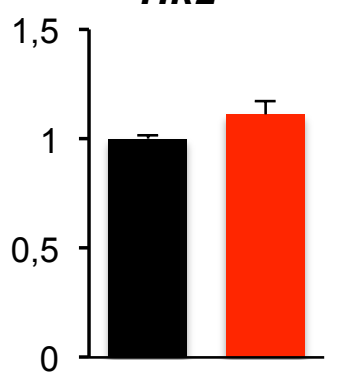

Tgf-1

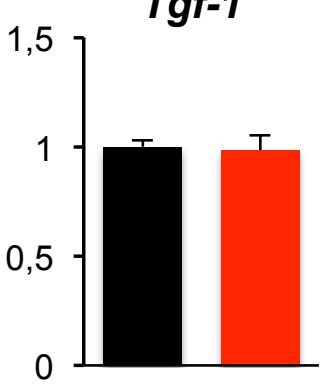

Igfbp3

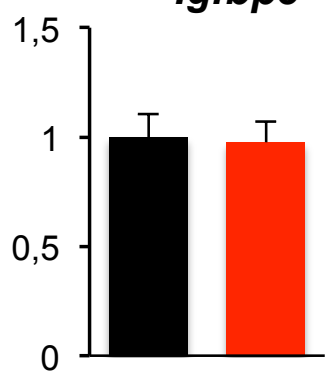

Vegf

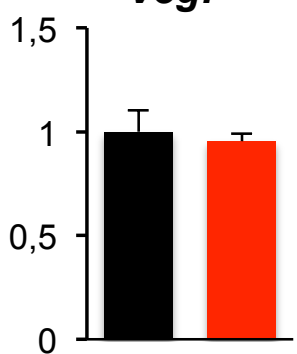

Figure 4.1 mRNA expression of hypoxia related genes comparing wt to $M e c p 2^{-/ y}$ mice

Means and standard deviations of mRNA levels of eight hypoxia genes when comparing wt (black bar) to $M e c p 2^{-1 y}$ mice (red bar) within VRC (P40; $\left.n=5\right)$, measured by running qRT-PCR.

The results revealed no statistically significant differences in the mRNA expressions of any of the hypoxia related genes analyzed between wt and $M e c p 2^{-/ y}$ mice.

\subsection{Systemic analysis of selected hypoxia-mediated mRNA and protein expression in the brain}

In the following section the genes Casp1, Hif1a, Trh, Trh-r1, and Trh-r2 will be analyzed systemically regarding their impact on breathing phenotype in Rett mice compared to wt mice. The underlying causes for all experiments will be described in more detail in the sections below.

\subsubsection{Analysis of Casp1 expression in the brain}

As noted above, the $R T^{2}$ Profiler PCR Array analysis revealed altered Casp1 expression levels between wt and $M e c p 2^{-1 y}$ mice. Consequently, the Casp1 gene expression was measured systemically and in more detail using qRT-PCR. Therefore total mRNA levels from 5 different brain areas were extracted. These areas include the cerebellum, cortex, hypothalamus, inferior olive, and VRC area. 
Firstly, to give an overview about general Casp1 mRNA distribution, Casp1 mRNA levels were measured throughout the brain areas of wt mice (4.2.1.1). Secondly, to contrast Casp1 mRNA levels within the brain areas of wt and Mecp2 ${ }^{-/ y}$ mice, Casp1 mRNA levels of both samples were measured and the results compared (4.2.1.2.).

\subsubsection{Analysis of Casp1 mRNA expression in wt mice in the brain}

Messenger RNA was isolated from different brain areas and transcribed into cDNA, which served as a template for qRT-PCR, used in the following two experiments (Figure 4.2).

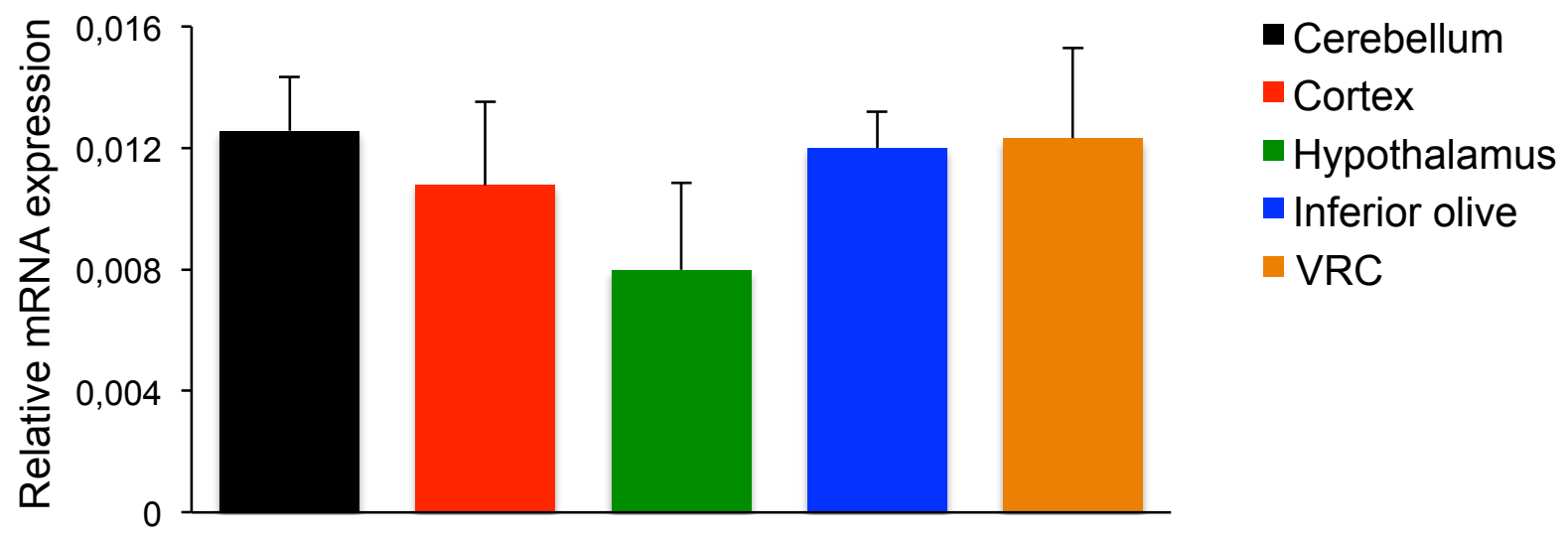

Figure 4.2 Casp1 mRNA expression in wt mice

Means and standard deviations of Casp1 mRNA levels within 5 brain areas of wt mice $(P 40 ; n=5)$, measured by running qRT-PCR (None of the values were significant; one-way ANOVA; Bonferroni's multiple comparison test).

The results demonstrated that Casp1 mRNA levels did not differ substantially between brain regions analyzed. The highest Casp1 mRNA level was identified in the cerebellum area. The lowest Casp1 mRNA level was identified in the hypothalamus region (0.635-fold compared to cerebellum). The VRC area demonstrated the second highest Casp1 mRNA level (0.98-fold compared to cerebellum).

\subsubsection{Analysis of Casp1 mRNA expression comparing wt to Mecp2 $^{-/ y} \mathrm{mice}$ in the brain}

In order to investigate Casp1 mRNA levels within the cerebellum, cortex, hypothalamus, inferior olive, and VRC of wt and Mecp $2^{-/ y}$ mice, Casp1 mRNA levels 
of both samples were measured and results compared (P40; $n=4$ to 5 ) (Figure 4.3).

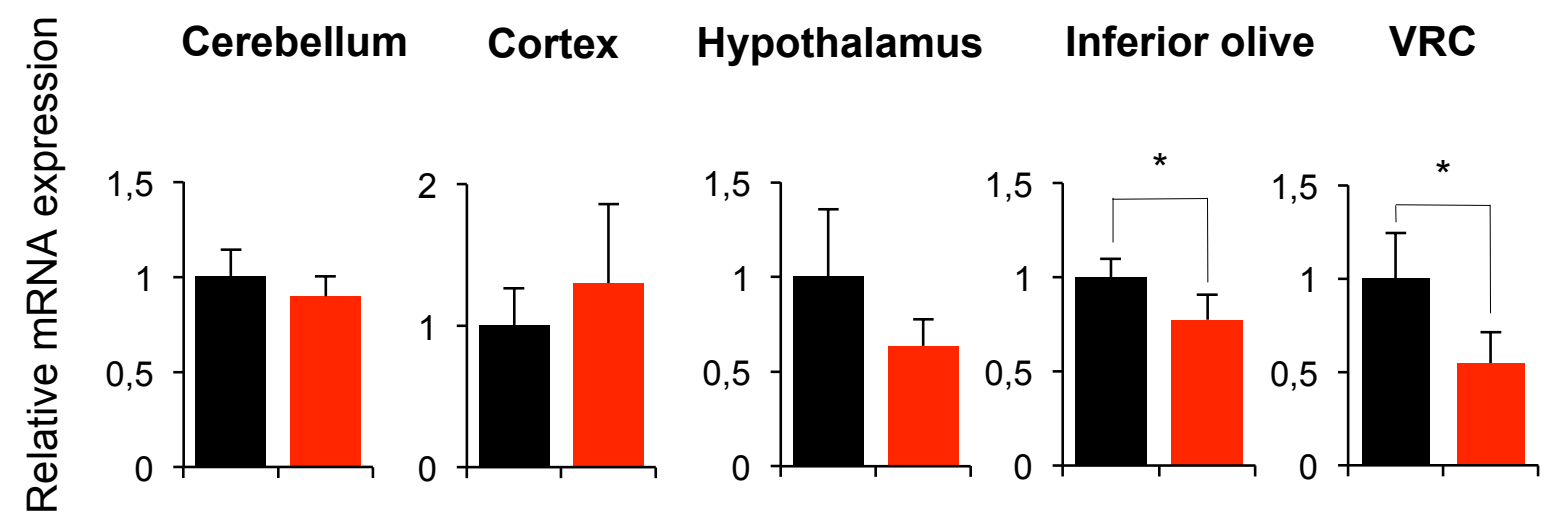

Figure 4.3 Casp1 mRNA expression comparing wt to $M e c p 2^{-/ y}$ mice

Means and standard deviations of Casp1 mRNA levels when comparing wt (black bar) to Mecp2 $2^{-1 y}$ mice (red bar) within 5 brain areas $(P 40 ; n=5)$, measured by running qRT-PCR. Wt was set to 1 . Asterisks indicate significance $\left({ }^{*}=p \leq 0.05\right.$; student's t-test).

The results showed no statistically significant differences in the Casp1 mRNA expressions of wt and $M e c p 2^{-1 / y}$ mice within cerebellum, cortex, and hypothalamus area. Significantly down-regulated mRNA values were found in the inferior olive area (wt vs. Mecp2-/y; $1.00 \pm 0.099$ vs. $0.774 \pm 0.132, p \leq 0.01$ ) and VRC area (wt vs. $M e c p 2^{-1 / y} ; 1.00 \pm 0.243$ vs. $\left.0.547 \pm 0.167 ; p \leq 0.01\right)$. The result of qRT-PCR cannot verify upregulation of Casp1 levels in $M e c p 2^{-/ y}$ mice compared to wt mice. This result indicates no hypoxia in $M e c p 2^{-1 y}$ mice compared to wt mice.

\subsubsection{Analysis of the HIF-1a system in the brain}

Fischer et al. (2009) demonstrated significant differences in protein expression in cerebellum and cortex. Thus, the Hif1a gene as well as its protein was studied regarding expression in wt and $M e c p 2^{-1 / y}$ mice (P40).

To assess systemic hypoxia, Hif1a mRNA levels from the five different brain areas (cerebellum, cortex, hypothalamus, inferior olive, and VRC) were extracted for qRTPCR method. Additionally, cerebellum and cortex tissues were used for protein analysis using western blot. 


\subsubsection{Analysis of Hif1a mRNA expression in wt mice in the brain}

To investigate the general Hif1a mRNA distribution, Hif1a mRNA levels were measured within the cerebellum, cortex, hypothalamus, inferior olive, and VRC of wt mice (P40; $n=5)$. mRNA was isolated and transcribed into cDNA serving as template for qRT-PCR (Figure 4.4).

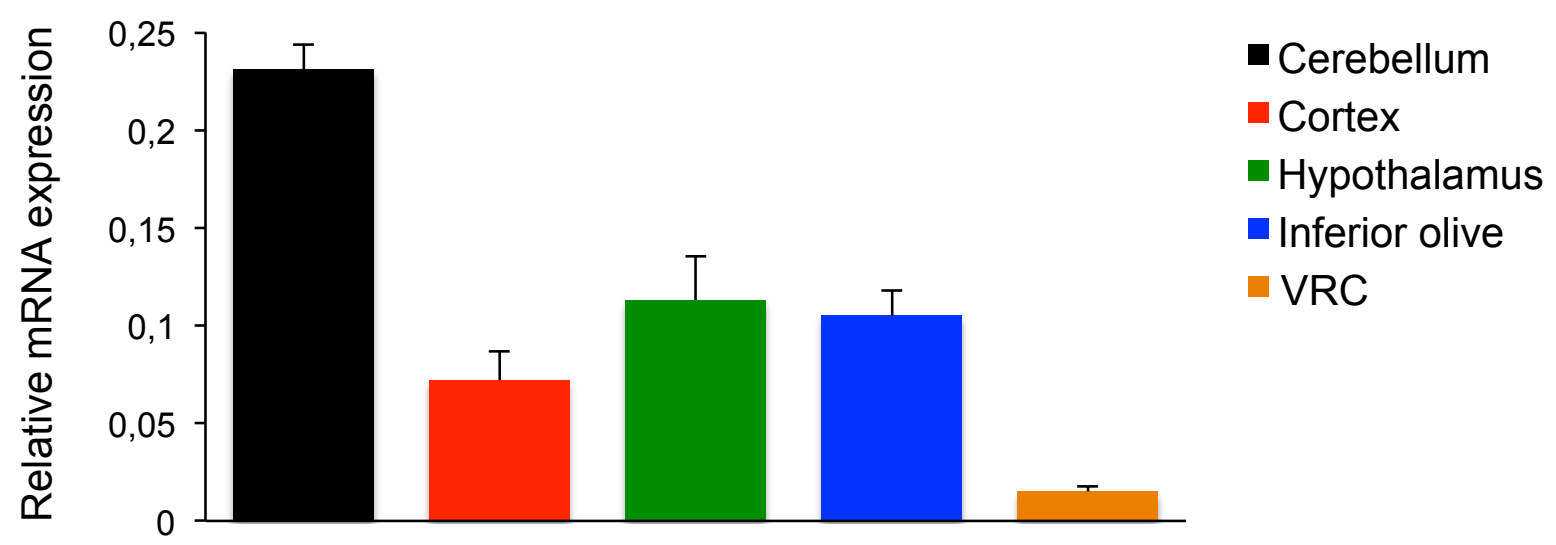

Figure 4.4 Hif1a mRNA expression in wt mice

Means and standard deviations of Hif1a mRNA levels within five brain areas of wt mice $(P 40 ; n=5)$, measured by running qRT-PCR (Asterisks indicate significance. Cerebellum (cb) vs. cortex (co) ****, cb vs. hypothalamus (hy) ${ }^{* * * *}$, cb vs. inferior olive (io) ${ }^{* * * *}$, cb vs. VRC ${ }^{* * * *}$, co vs. hy ${ }^{*}$, co vs. VRC ${ }^{* * *}$, hy vs. VRC ${ }^{* * * *}$, io vs. VRC ${ }^{* * * *} ;{ }^{*}=p \leq 0.05 ;{ }^{* * *}=p \leq 0.001 ;{ }^{* * * *}=p \leq 0.0001$; one-way ANOVA; Bonferroni's multiple comparison test).

The results demonstrated that the cerebellum area had the highest Hif1a mRNA levels of all brain areas tested. The breathing-related VRC area indicated the lowest Hif1a mRNA levels (0.065-fold compared to cerebellum). The cortex (0.312-fold compared to cerebellum), hypothalamus (0.489-fold compared to cerebellum), as well as the inferior olive area (0.454-fold compared to cerebellum) showed almost identical expressions.

\subsubsection{Analysis of Hif1a mRNA expression comparing wt to Mecp2-/y mice in the brain}

To compare Hif1a mRNA levels within the cerebellum, cortex, hypothalamus, inferior olive, and VRC of wt and Mecp2 $2^{-/ y}$ mice, Hif1a mRNA levels of both samples were measured and results compared (P40; $n=5)$. 


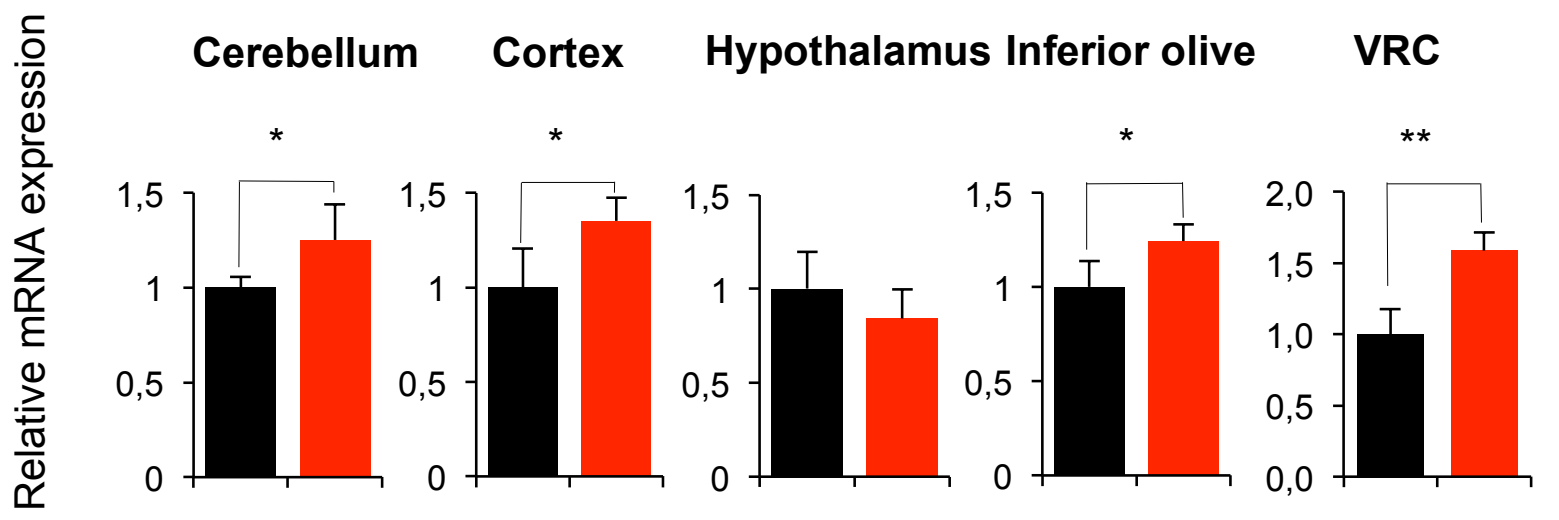

Figure 4.5 Hif1a mRNA expression comparing wt to $M_{\text {ecp2 }}^{-/ y}$ mice

Means and standard deviations of Hif1a mRNA levels when comparing wt (black bars) to Mecp $2^{-/ y}$ mice (red bars) within five brain areas (P40; $n=5)$, measured by running qRT-PCR. Wt was set to 1 . Asterisks indicate significance $\left({ }^{*}=p \leq 0.05 ;{ }^{* *}=p \leq 0.01\right.$; student's t-test).

Results demonstrated that the brain areas of the $M е с p 2^{-/ y}$ mice have significantly higher Hif1a mRNA levels compared to wt mice: Hif1a mRNA levels in the cerebellum area of wt mice were $1.00 \pm 0.054$ and $M e c p 2^{-1 y}$ mice were $1.251 \pm$ 0.186 ( $p$ < 0.05). A similar deregulation dimension was observed in the inferior olive area (wt vs. $M e c p 2^{-/ y} ; 1.00 \pm 0.136$ vs. $1.244 \pm 0.09 ; p \leq 0.05$ ). The cortex area even showed higher up-regulation in $M e c p 2^{-/ y}$ mice compared to wt mice (wt vs. Mecp2 $2^{-/ y}$; $1.00 \pm 0.205$ vs. $1.352 \pm 0.122 ; p \leq 0.05$ ). The breathing-correlated VRC area indicated the highest deregulation of all brain areas (wt vs. Mecp $2^{-1 / y} ; 1.00 \pm 0.175$ vs. $1.588 \pm 0.128 ; p \leq 0.05$ ). Only the hypothalamus area of the $M e c p 2^{-1 y}$ mice showed no statistically significant difference compared to wt mice.

\subsubsection{Analysis of HIF-1 $\alpha$ protein expression comparing wt to Mecp2 $^{-/ y}$ mice in the brain}

In order to investigate HIF-1 $\alpha$ protein levels within the cerebellum and cortex area of wt and $M e c p 2^{-1 y}$ mice at P40, western blot analysis was conducted ( $n=3$ independent experiments). The western blot experiment indicated specific signals at $36 \mathrm{kDa}$ for the housekeeping protein GAPDH and $120 \mathrm{kDa}$ for HIF-1a. This result is in line with the expected molecular mass of corresponding proteins (Figure 4.6 and Figure 4.7). 
Results

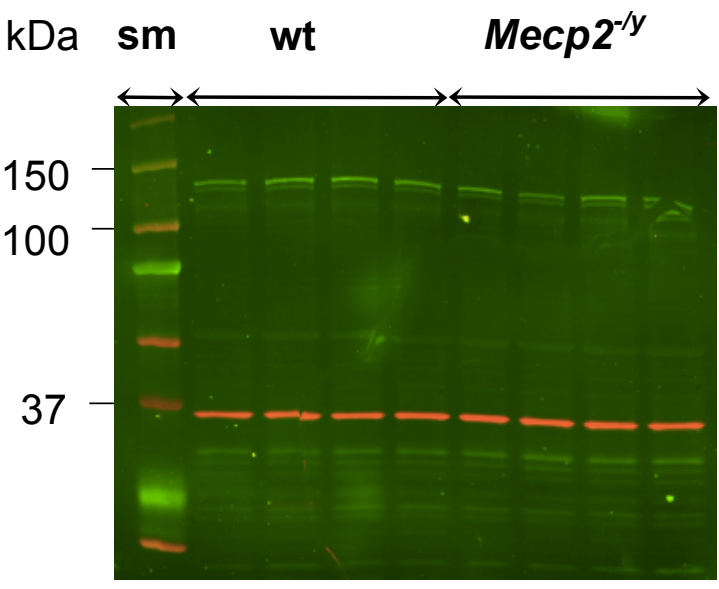

cerebellum

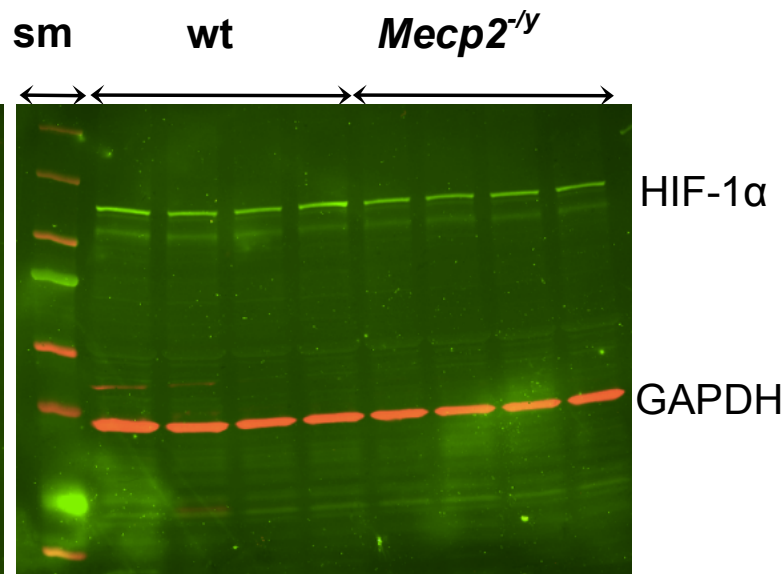

cortex

Figure 4.6 HIF-1 $\alpha$ western blot comparing wt to $M_{\text {ecp2 }}{ }^{-1 y}$ mice

Western blot analysis of HIF-1a protein within two brain areas in wt and $M e c p 2^{-1 y}$ mice (P40; $n=4$ animals each). For the western blot experiment $60 \mu \mathrm{g}$ of total protein per lane was loaded. $10 \mu \mathrm{l}$ of size marker (sm) was applied in first left slot; and a primary antibody of HIF-1 $\alpha$ was applied at a concentration level of 1:1,000 as well as a primary antibody of GAPDH at a concentration level of 1:15,000. Both antibodies were diluted in $2.5 \%$ BSA in TBS-T. Secondary antibodies were diluted in same solution at a concentration level of 1:10,000 (HIF-1 $\alpha$ ) respectively 1:15,000 (GAPDH).

\section{Cerebellum}

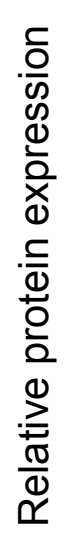

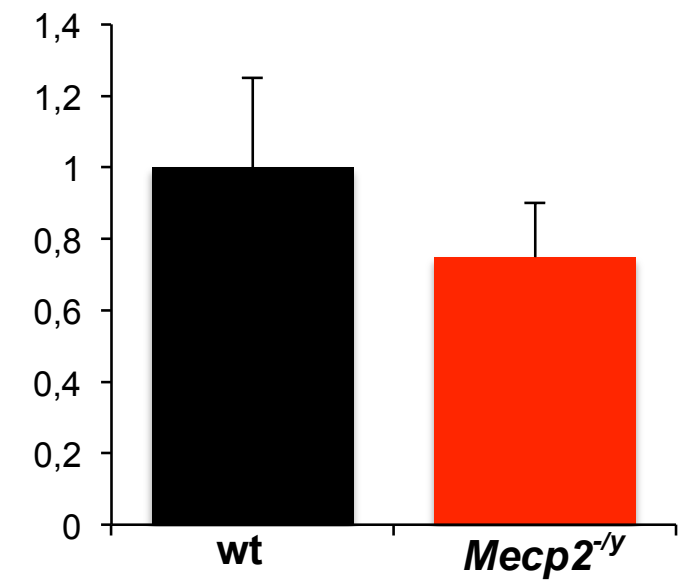

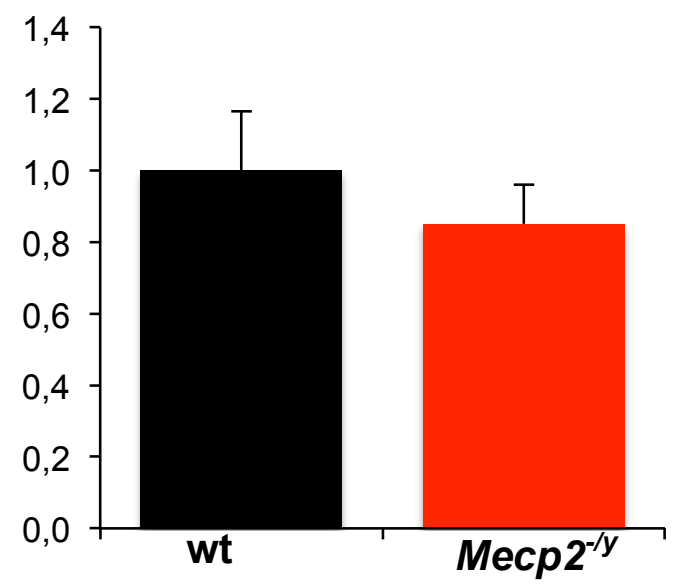

Figure 4.7 HIF-1a protein expression comparing wt to $M e c p 2^{-/ y}$ mice

Means and standard deviations of HIF-1 $1 \alpha$ protein levels within two brain areas when comparing wt (black bars) to $M e c p 2^{-1 y}$ mice (red bars) using a western blot analysis $(P 40 ; n=4)$. Wt was set to 1 .

Densitometric analysis of the specific western blot signals did not show any statistical differences in HIF-1a protein expressions between wt and $M e c p 2^{-/ y}$ mice neither in the cerebellum nor in the cortex. 


\subsubsection{Analysis of Trh expression in the brain}

In the following section the Trh system (the Trh gene as well as its receptors Trh-r1 and Trh-r2) will be analyzed. The experiments were motivated by the following three assumptions:

First of all, the characterictics of $M e c p 2^{-/ y}$ mice include dehydration and reduced body mass (see 1.1.3 The mouse model of Rett syndrome), which might be a result of thyroid hyperfunction. TRH is the origin of a hormone cascade to stimulate building and releasing of triiodothyronine $\left(T_{3}\right)$ and tetraiodothyronine $\left(T_{4}\right)$ in the thyroid glands. In addition the Trh system plays a key role within and acts to modulate areas of the respiratory network. Thus, this research proposed that Trh levels are dysregulated in $M e c p 2^{-/ y}$ mice compared to wt mice. Furthermore, the experiments of Manzke et al. (2007) indicated differing expression levels of the Trh hormone in the VRC when comparing Mecp2 $2^{-/ y}$ with wt mice (P40). This research assumes a correlation between cerebral Trh levels and hypoxia in $M e c p 2^{-/ y}$ mice.

Trh mRNA levels were extracted from five different brain areas. The areas included the cerebellum, cortex, hypothalamus, inferior olive, and VRC.

First, to give an overview about the general Trh mRNA distribution, Trh mRNA levels were measured within the above brain areas of wt mice (4.2.3.1). Second, to compare Trh mRNA levels within the brain areas of wt and $M e c p 2^{-/ y}$ mice, Trh mRNA levels of both samples were measured and the results compared (4.2.3.2). 


\subsubsection{Analysis of Trh mRNA expression in wt mice in the brain}

To investigate the general Trh mRNA distribution, Trh mRNA levels were measured within the cerebellum, cortex, hypothalamus, inferior olive, and VRC of wt mice $(P 40 ; n=5)$. Messenger RNA was isolated and transcribed into cDNA. The samples served as a template for the qRT-PCR, used in the following two experiments.

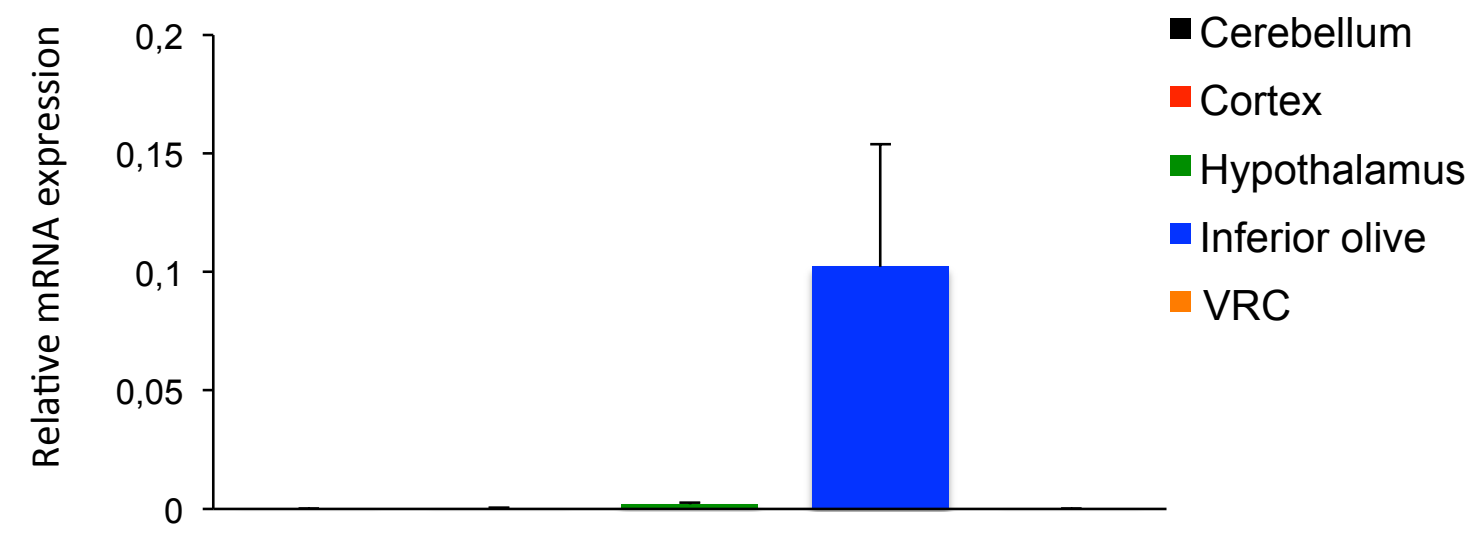

Figure 4.8 Trh mRNA expression in wt mice

Means and standard deviations of Trh mRNA levels within five brain areas of wt mice (P40;n = 5), measured by running qRT-PCR (Asterisks indicate significance. $\mathrm{Cb}$ vs. io ${ }^{* * *}$, $\mathrm{Co}$ vs. io ${ }^{* * *}$, hy vs. io ${ }^{* * *}$, io vs. VRC ${ }^{* * *} ;{ }^{* * *}=p \leq 0.001$; one-way ANOVA; Bonferroni's multiple comparison test).

The results demonstrated that the inferior olive area has the highest Trh mRNA levels of all brain areas tested (703.458-fold compared to the cerebellum area). The second highest Trh mRNA levels have been identified in the hypothalamus region (13.497-fold).

The breathing-related VRC area (0.463-fold compared to the cerebellum area) and the cortex area (1.555-fold compared to cerebellum) showed the second-lowest Trh mRNA levels.

\subsubsection{Analysis of Trh mRNA expression comparing wt to $\mathrm{Mecp}^{-1 /}$ mice in $^{-1}$ the brain}

To compare Trh mRNA levels within the cerebellum, cortex, hypothalamus, inferior olive, and VRC of wt and Mecp2 $2^{-/ y}$ mice, Trh mRNA levels of both samples were measured and results compared (P40; $n=5)$ (Figure 4.9). 

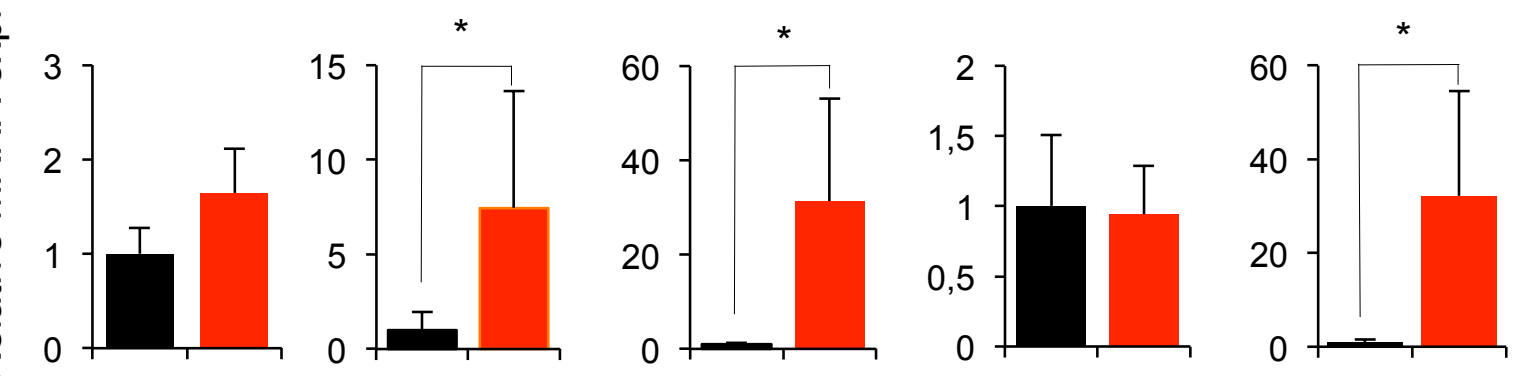

Figure 4.9 Trh mRNA expression comparing wt to $M e c p 2^{-/ y}$ mice

Means and standard deviations of Trh mRNA levels when comparing wt (black bars) to Mecp2 $2^{-1 y}$ mice (red bars) within five brain areas (P40; $n=5)$, measured by running qRT-PCR. Wt was set to 1 . Asterisks indicate significance $\left({ }^{*}=p \leq 0.05\right.$; student's t-test $)$.

The experiment revealed higher Trh mRNA levels in the cortex (wt vs. Mecp2-1y; $1.00 \pm 0.949$ vs. $7.445 \pm 6.179 ; p \leq 0.05$ ), hypothalamus (wt vs. Mecp2 $2^{-1 y} ; 1.00 \pm$ 0.291 vs. $31.374 \pm 21.677 ; p \leq 0.05$ ), and VRC area (wt vs. Mecp $2^{-1 y} ; 1.00 \pm 0.544$ vs. $32.214 \pm 22.372 ; p \leq 0.05$ ). The cerebellum and inferior olive area demonstrated no statistically significant difference.

\subsubsection{Analysis of Trh-r1 expression in the brain}

Because the $M e c p 2^{-1 y}$ mice showed a significant increase in Trh compared to wt mice in almost all brain areas analyzed and the TRH function depends on the interaction with its two different receptor subtypes (Trh-r1 and Trh-r2), it was of interest to explore the region-specific expression levels of Trh-r1 and Trh-r2 and to compare them between wt and $M e c p 2^{-/ y}$ mouse models.

To assess the systemic hypoxia, Trh-r1 mRNA levels from five different brain areas were extracted. The areas include the cerebellum, cortex, hypothalamus, inferior olive, and VRC.

First, to give an overview about general Trh-r1 mRNA distribution, Trh-r1 mRNA levels were measured within the above brain areas of wt mice (4.2.4.1). Second, to compare Trh-r1 mRNA levels within the brain areas of wt and Mecp2-1y mice, Trh-r1 mRNA levels of both samples were measured and the results compared (4.2.4.2). 


\subsubsection{Analysis of Trh-r1 mRNA expression in wt mice in the brain}

To investigate the general Trh-r1 mRNA distribution, Trh-r1 mRNA levels were measured within the cerebellum, cortex, hypothalamus, inferior olive, and VRC of wt mice $(P 40 ; n=5)$. mRNA was isolated from the different brain areas and transcribed into cDNA. The samples gained served as a template for the qRT-PCR, used in the following two experiments (Figure 4.10).

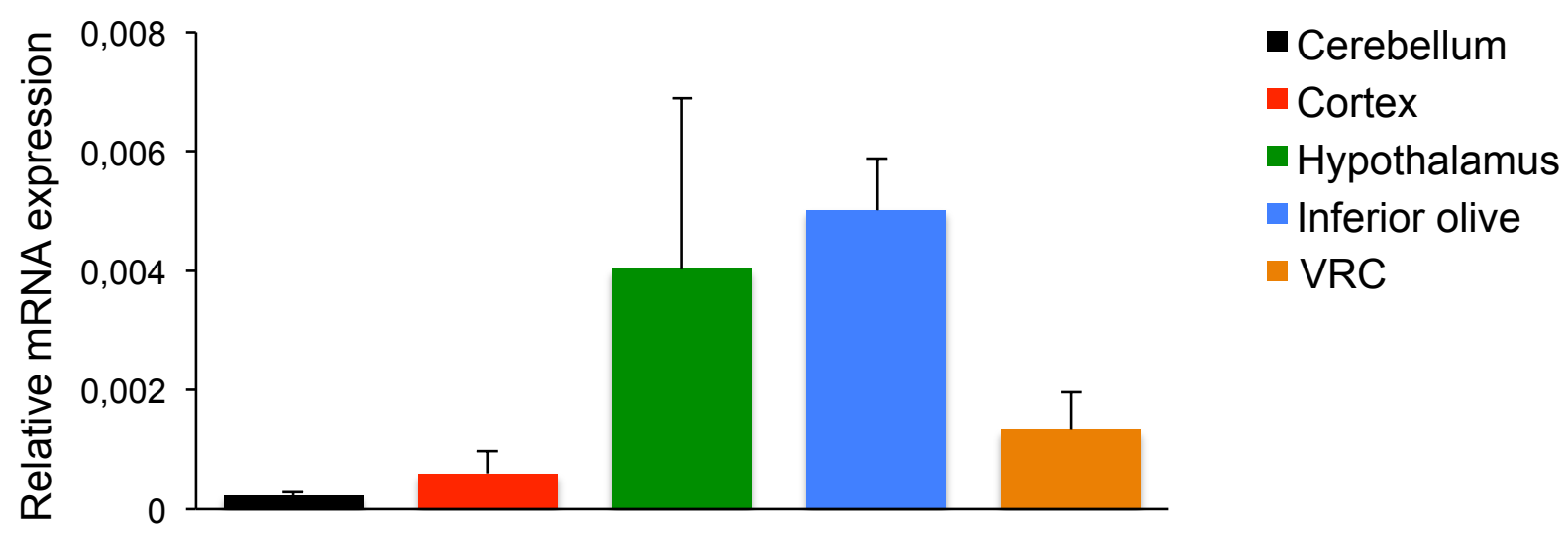

Figure 4.10 Trh-r1 mRNA expression in wt mice

Means and standard deviations of Trh-r1 mRNA levels within five brain areas of wt mice $(P 40 ; n=5)$, measured by running qRT-PCR (Asterisks indicate significance. Cb vs. hy ${ }^{*}$, cb vs. io ${ }^{* *}$, co vs. hy *, co vs. io ${ }^{* *}$, io vs. VRC ${ }^{* *} ;{ }^{*}=p \leq 0.05 ;{ }^{* *}=p \leq 0,01$; one-way ANOVA; Bonferroni's multiple comparison test).

The highest Trh-r1 mRNA levels were identified in the inferior olive area. This result was in accordance with the Trh mRNA levels measured in the same brain region above (4.2.3.1) (21.609-fold compared to cerebellum). In addition, high Trh-r1 mRNA levels were identified in the hypothalamus area (17.337-fold). The cerebellum, cortex, and VRC regions demonstrated low expressions on a similar level. Interestingly, on average the Trh-r1 levels (mean value 0.002) were approximately one-tenth of the Trh mRNA levels identified above (mean value $0.021)$.

\subsubsection{Analysis of Trh-r1 mRNA expression comparing wt to Mecp2 $^{-/ y}$ mice in the brain}

Subsequently, Trh-r1 mRNA levels within the brain areas (cerebellum, cortex, hypothalamus, inferior olive, and VRC) of wt and $M e c p 2^{-/ y}$ mice were compared. Trh-r1 mRNA levels of both samples were measured and results compared (P40; $n$ =5) (Figure 4.11). 


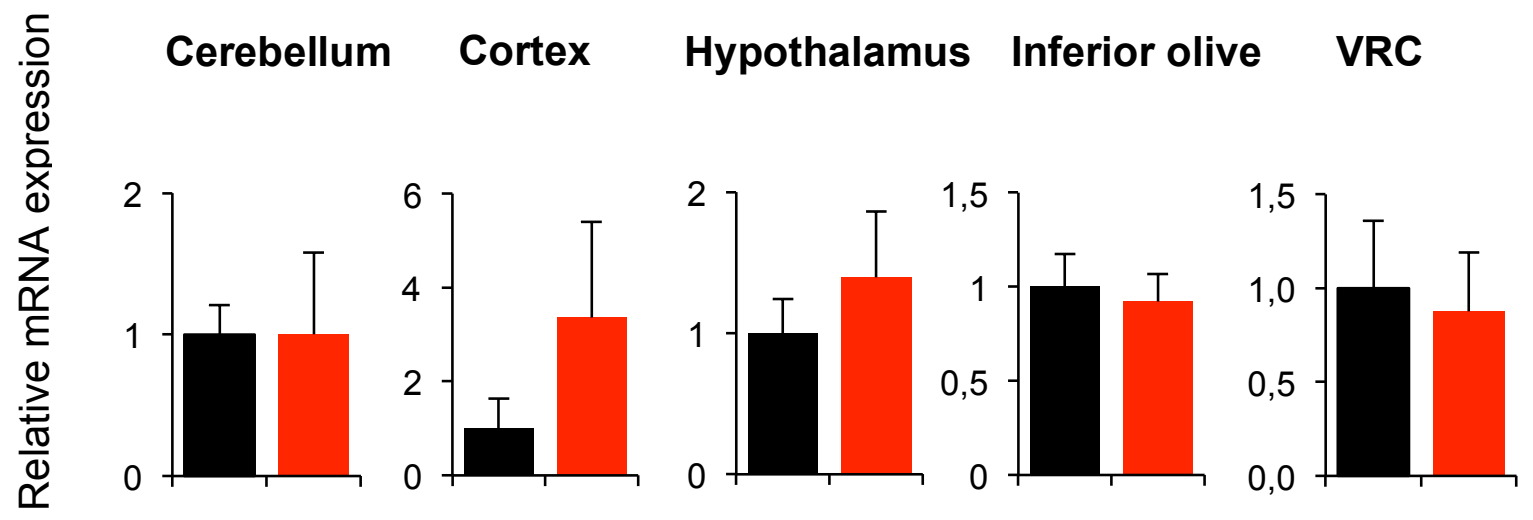

Figure 4.11 Trh-r1 mRNA expression comparing wt to $M e c p 2^{-/ y}$ mice

Means and standard deviations of Trh-r1 mRNA levels when comparing wt (black bars) to Mecp2 $2^{-1 y}$ mice (red bars) within five brain areas (P40; $n=5)$, measured by running qRT-PCR. Wt was set to 1 .

The results demonstrated that there were no statistically significant differences in the Trh-r1 mRNA expressions of wt and $M e c p 2^{-/ y}$ mice.

\subsubsection{Analysis of Trh-r2 expression in the brain}

In this section Trh-r2 expression will be explored accordingly to analysis of Trh-r1 expression.

To assess the systemic hypoxia, Trh-r2 mRNA levels from five different brain areas were extracted. The areas include the cerebellum, cortex, hypothalamus, inferior olive, and VRC.

First, to give an overview about general Trh-r2 mRNA distribution, Trh-r2 mRNA levels were measured within the above brain areas of wt mice (4.2.5.1). Second, to compare Trh-r2 mRNA levels within the brain areas of wt and Mecp2 $2^{-/ y}$ mice, Trh-r2 mRNA levels of both samples were measured and the results compared (4.2.5.2).

\subsubsection{Analysis of Trh-r2 mRNA expression in wt mice in the brain}

To investigate the general Trh-r2 mRNA distribution, Trh-r2 mRNA levels were measured within the cerebellum, cortex, hypothalamus, inferior olive, and VRC of wt mice $(P 40 ; n=5)$. mRNA was isolated from the different brain areas and transcribed into cDNA. The samples gained served as a template for the qRT-PCR, used in the following two experiments (Figure 4.12). 


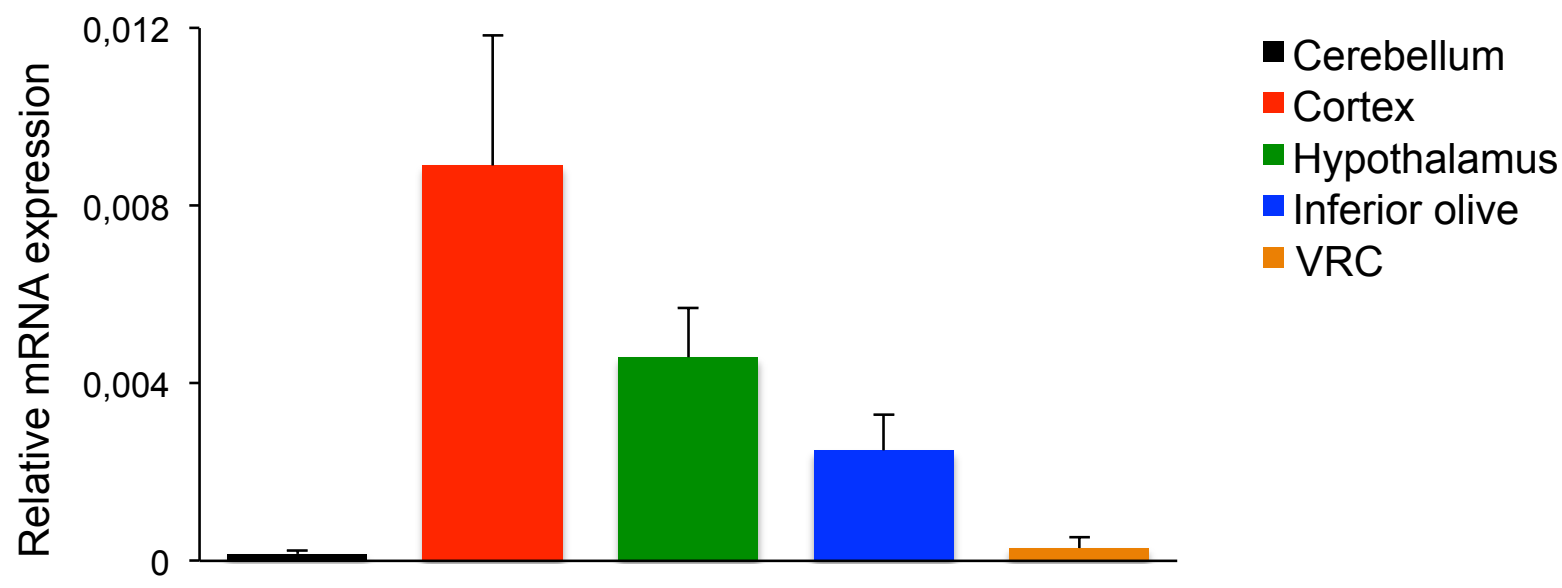

Figure 4.12 Trh-r2 mRNA expression in wt mice

Means and standard deviations of Trh-r2 mRNA levels within five brain areas of wt mice (P40;n = 5), measured by running qRT-PCR (Asterisks indicate significance. $\mathrm{Cb}$ vs. co ${ }^{* * * *}, \mathrm{cb}$ vs. hy ${ }^{* *}, \mathrm{co}$ vs. hy ${ }^{* *}$, co vs. io ${ }^{* * *}$, co vs. VRC ${ }^{* * * *}$, hy vs. VRC ${ }^{* *} ;{ }^{* *}=p \leq 0.01 ;{ }^{* * *}=p \leq 0,001 ;{ }^{* * * *}=p \leq 0,0001$; oneway ANOVA; Bonferroni's multiple comparison test).

The experiment revealed that the highest Trh-r2 mRNA levels exist in the cortex area (58.112-fold compared to the cerebellum area), followed by the Trh-r2 mRNA levels of the hypothalamus (29.921-fold compared to the cerebellum area), inferior olive (16.256-fold compared to the cerebellum area), and VRC area (1.89-fold compared to the cerebellum area). The Trh-r2 mRNA expression in the inferior olive area is particularly interesting, since it is much lower than the Trh expression measured in 4.2.3.1. On average the Trh-r2 levels (mean value 0.003) are almost identical to the Trh-r1 levels identified above (mean value 0.002).

\subsubsection{Analysis of Trh-r2 mRNA expression comparing wt to $\mathrm{Mecp2}^{-/ y}$ mice in the brain}

In comparison, Trh-r2 mRNA levels within the brain areas (cerebellum, cortex, hypothalamus, inferior olive, and VRC) of wt and $M e c p 2^{-/ y}$ mice were measured and results compared (P40; $n=5)$ (Figure 4.13). 


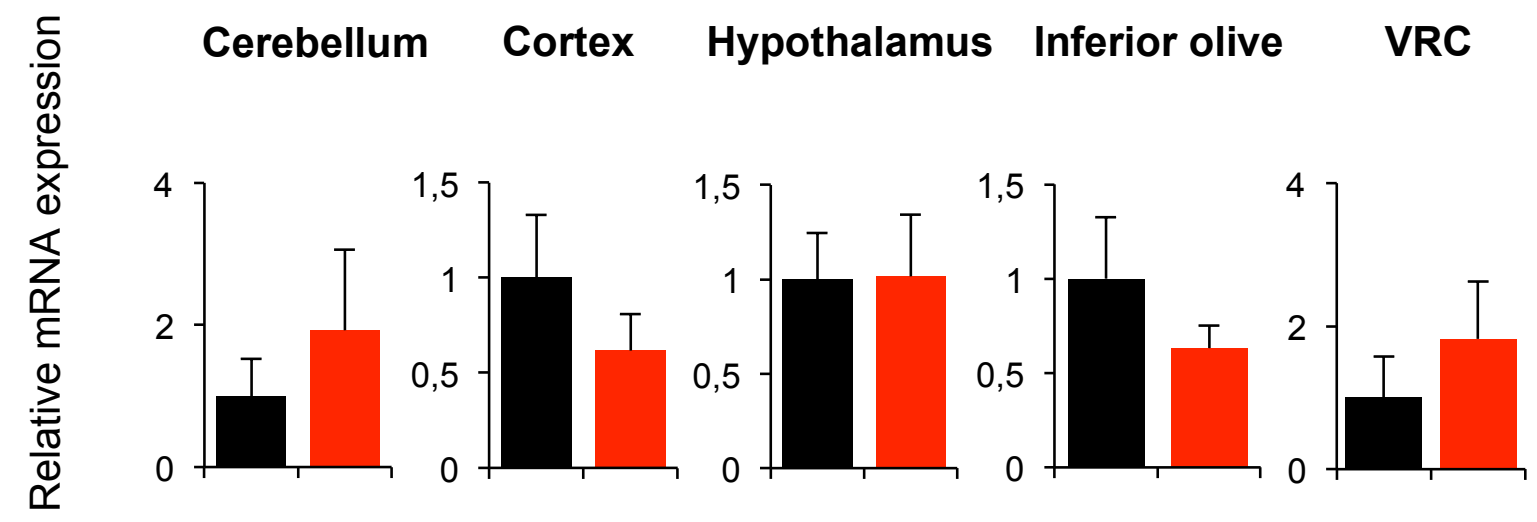

Figure 4.13 Trh-r2 mRNA expression comparing wt to $M_{\text {ecp2 }}{ }^{-/ y}$ mice

Means and standard deviations of Trh-r2 mRNA levels when comparing wt (black bars) to Mecp $2^{-/ y}$ mice (red bars) within five brain areas (P40; $n=5)$, measured by running qRT-PCR. Wt was set to 1 .

The results demonstrated no statistically significant differences in the Trh-r2 mRNA expressions of wt and Mecp2-ly mice. 


\section{Discussion, implications and further research}

Several researchers identified major life-threatening breathing characteristics in $M{ }^{2} 2^{-1 y}$ mice (Ward et al. 2011), such as irregularities of frequency and amplitude (Ramirez et al. 2013), apneas (Stettner et al. 2008), as well as tachypnea (Ogier et al. 2007) (see 1.1.4 Breathing impairment in $M e c p 2^{-/ y}$ mice). Moreover, it was found that life-threatening breathing conditions in RTT patients may lead to decreased oxygen saturation and, in worst case, to sudden death (Glaze 2005). In order to find genetic symptoms of systemic cerebral hypoxia under such circumstances, gene and protein expression levels in specific brain areas of $M e c p 2^{-1 y}$ mice were examined and compared with wt. The aim of these experiments was to find evidence for hypothesis 1: If Mecp $2^{-1 y}$ mice suffer under breathing imbalance, this would induce hypoxic conditions.

\subsection{General hypoxia-mediated mRNA expression is not modified in the brain}

To obtain hypoxia indicators, a $R T^{2}$ Profiler PCR Array: Hypoxia Signaling Pathway test was performed, scanning the expression levels of 84 hypoxia genes in the VRC area for significant alterations between wt and $M e c p 2^{-/ y}$ mice. None of these genes showed any statistically significant differences in their expression levels, except for the apoptosis gene Casp1 which will be discussed in section 5.2. Hence, this experiment did not reveal any indicators that hypoxia in $M e c p 2^{-1 y}$ mouse brains exist.

To further analyze putative hypoxia in $M e c p 2^{-/ y}$ mice brains, eight genes ( $A d m$, Gpi1, Hk2, Igfbp-3, II-1, S/c2a3, Tgf-1, Vegf) that have been frequently listed as major indicators for hypoxia were tested using qRT-PCR. None of these genes showed any regulation in the $\mathrm{VRC}$ area of $M e c p 2^{-/ y}$ mice compared to wt mice. Like the experiment above, this test did not reveal any evidence that hypoxia in $M e c p 2^{-/ y}$ mouse brains occurs.

Because only one deregulated hypoxia gene had been identified in the first experiment, and none of the eight strongly hypoxia related genes have been found to be regulated in wt mice compared to $M e c p 2^{-/ y}$ mice in a second experiment, this 
study suggested that hypoxic conditions in $M e c p 2^{-1 y}$ mice solely manifest in a physiological manner, e.g. by apneas or tachypnea.

\subsection{Casp1 expression is not modified in the brain}

As described above, only Casp1 had been identified in the first experiment, and none of the eight strongly hypoxia related genes were found to be regulated in $M e c p 2^{-/ y}$ mice compared to wt mice in the second experiment.

Casp1, primarily acts as a protease (Nicholson and Thornberry 1997), involved in the apoptosis cascade (Hilbi et al. 1998). Most importantly, however, it plays a prominent role concerning cellular response to severe damage, e.g. caused by hypoxia (Clark et al. 1999). The $R T^{2}$ Profiler PCR Array: Hypoxia Signaling Pathway test has revealed a 2.809-fold up-regulation of Casp1 expression levels in Mecp2-/y mice brain, in comparison to wt mice brains. Furthermore, Russell et al. (2007) found, that exposing isolated $M e c p 2^{-/}$and wt cerebellum neurons in vitro to hypoxia lead to a higher Casp1 level in Mecp2 $2^{-/}$neurons than in wt neurons. This indicates a different response of neurons to hypoxia depending on their Mecp2 levels. It was thus decided to analyze Casp1 in more detail, using a qRT-PCR analysis.

The experiment revealed significantly lower Casp1 expression levels in the inferior olive and VRC area of $M e c p 2^{-/ y}$ mice when compared to wt mice. Other brain regions did not show any alterations in $M e c p 2^{-1 / y}$ mice.

One reason, explaining no visible apoptosis condition might be the activating impact of MeCP2 on Casp1: MeCP2 does not exist in Mecp2-1y mice. This leads to a lower activating stimulus on the Casp1 expression levels. Therefore, the Casp1 expression levels in $M e c p 2^{-/ y}$ mice brains are reduced compared to wt mice. As a consequence, neurons within $M e c p 2^{-1 y}$ mice brains are unable to react adequately to rough neuronal damages. Subsequently, neurons, e.g. within the VRC area, undergo unregulated neuronal death. This destruction of neurons by necrosis, e.g. in the VRC area, manifests itself in typical Rett symptoms, such as breathing disorders. Necrosis describes the loss of control regarding cell death, which directly leads to autolysis and the release of inflammatory factors (Fink and Cookson 2005). Maezawa and Jin (2010) found significantly less necrosis indicating TNF- $\alpha$ release in $M e c p 2^{-1 y}$ microglia than in the wt mice after stimulation. They expect constitutively higher expression levels in $M e c p 2^{-1 y}$ mice. Furthermore, neurons are exclusively 
involved in the oxygen gene synthesis, e.g. in the oxygen gene synthesis of Hif1a. Because neurons are exclusively involved in the production of survival assuring genes, the oxygen gene synthesis suppresses Casp1 synthesis.

It should be noted, however, that the results of the qRT-PCR analysis conflicts with the findings of Russell et al. (2007). A possible reason for this deviation could be the different methods used in both studies. For example, the mice analyzed within this study did not undergo any oxygen deficiency whereas Russell et al. (2007) examined neurons of $M e c p 2^{-/}$mice after exposing them six hours to hypoxia. The initial results from the $R T^{2}$ Profiler PCR Array: Hypoxia Signaling Pathway test could be explained by measuring inaccuracies. Consequently, doing technical as well as biological repeats would reduce these errors.

\subsection{The HIF-1a system is not modified in the brain}

As none of the above experiments provided evidence required to validate hypothesis 1 , literature, which supports the hypothesis 1 has been studied in more detail. A recent study, which confirmed the hypothesis of hypoxia in $M e c p 2^{-/ y}$ mice, is the work by Fischer et al. (2009). Fischer et al. (2009) identified elevated HIF-1a expression levels in the cerebellum and cortex area of $M e c p 2^{-/ y}$ mice.

The hypoxia induced transcription factor HIF-1 $\alpha$ (Wiener et al. 1996) regulates cell functions in condition of low oxygen levels (Zinkernagel et al. 2007). The operation

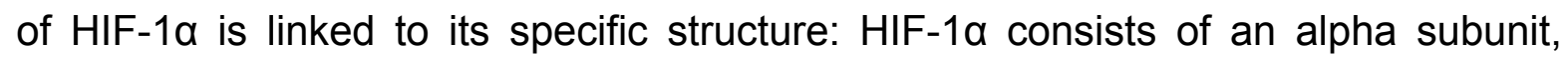
which is degraded by ubiquitination under normoxic conditions (Tanimoto et al. 2000) and the beta subunit, which is constitutively expressed (Yu et al. 1998).

When hypoxia occurs, HIF-1a regulation is considered to occur at the protein level. Studies, which have identified Hif1a regulation at the RNA level, however, are still limited. One of the few studies, which identified Hif1a regulation at the gene level, is the research of Van Uden et al. (2008). They found Hif1a regulation at the gene level caused by the apoptosis factor NF-kb. It should be noted, however, that the research was concentrated on the kidney of mice only, and did not include the brain.

Under hypoxic conditions, the protein HIF-1 $\alpha$ becomes stabilized and genes, such as erythropoietin (Epo), vascular endothelial growth factor (Vegf), and lactate 
dehydrogenase $A$ ( $L d h a)$ become activated. These genes are necessary to adjust hypoxic cells to the low oxygen saturation (Pugh and Ratcliffe 2003, Hu et al. 2003). Furthermore, the generation and maturation of erythrocytes increases, angiogenesis is stimulated and glucose metabolism is converted into an anaerobic mode.

To reassess the results of Fischer et al. (2009) and to examine, whether the hypothesis of hypoxia in $M e c p 2^{-1 y}$ mouse models can be maintained, a further systemic analysis was performed.

\subsubsection{HIF-1a protein expression is not modified in the brain}

The results of Fischer et al. were reassessed by including the observations of Schüle et al. (2008). Schüle et al. (2008) reported rare cases of male Rett patients that died at the age of 15 months. According to Schüle et al. (2008) causes of death were central breathing failure, respiratory arrest, and chronic hypoxia. Consequently, a second hypothesis was developed:

Hypothesis 2: If human male Rett patients die by respiratory failure, cerebral hypoxia must exist in Mecp $2^{-1 y}$ mice when compared to wt mice.

As well as comparing the results of Fischer et al. (2009) with Schüle et al. (2008) the results from Fischer et al were reassessed by including the observations of Chen et al. (2001). Chen et al. (2001) found that Rett symptoms of $M e c p 2^{-/ 4}$ mice are rather harmless and develop relatively late when compared to $M e c p 2^{-1 y}$ mice. $M e c p 2^{-/+}$mice are female mice, which only possess one Mecp2 knockout chromosome and consequently another non-affected chromosome. It was assumed that the harmless and relatively delayed symptoms of $M c 2^{-/+}$mice could be substantiated by an improved respiratory phenotype. Hence, the improved respiratory phenotype causes less severe hypoxia and lower neuronal damage. A third hypothesis was determined:

Hypothesis 3: If female Mecp $2^{-/+}$mice show improved respiration and therefor less Rett symptoms compared to male Mecp2-1y mice, cerebral hypoxia must be existent in $\mathrm{Mecp}^{-/ y}$ mice.

Protein levels of HIF-1 $\alpha$ were investigated in the cerebellum and the cortex of $M e c p 2^{-1 y}$ mice and wt mice using western blot analysis. This experiment was carried 
out to reassess the findings of Fischer et al. (2009). Initially, the results were described and brought into context of the current literature in general. Furthermore, the results were compared to the results of Fischer et al. (2009).

The experiment revealed that HIF-1 $\alpha$ protein levels were not significantly regulated in $M_{e c p 2^{-1 y}}$ mice. Since HIF-1a is an important hypoxia indicator, hypothesis 1, 3, and 4 have to be rejected.

Hypothesis 1: Mecp2-1y mice compared to wt mice suffer under breathing imbalance that nonetheless does not induce hypoxic conditions.

Hypothesis 2: Although human male Rett patients die by respiratory failure, cerebral hypoxia does not exist in Mecp2-/y mice.

Hypothesis 3: Although female Mecp $2^{+/}$mice show improved respiration and therefor less Rett symptoms compared to male $M e c p 2^{-1 y}$ mice, cerebral hypoxia is not existent in $\mathrm{Mecp}^{-1 / y}$ mice.

\subsubsection{Hif1a mRNA expression is modified in the brain}

To find out whether hypoxia occurs in $M e c p 2^{-1 y}$ mice compared to wt mice at all, experiments were set up and Hif1a expression levels systemically measured within five brain areas. These experiments revealed that all brain areas examined had a significantly higher Hif1a expression level in $M e c p 2^{-/ y}$ mice brains when compared to wt mice, except for in the hypothalamus area. The hypothalamus area did not show any regulation in $M e c p 2^{-1 y}$ mice. The up-regulation of Hif1a in four brain areas of $M e c p 2^{-1 y}$ mice compared to wt mice therefore contributes to the limited amount of studies, which identified similar results (e.g. Van Uden et al. 2008).

Reasons, which might explain that Hif1a mRNA expression levels were upregulated while protein levels of HIF-1a were not increased, are as follows:

Firstly, Hif1a mRNA expression levels might be significantly regulated in $M e c p 2^{-/ y}$ mouse brains due to the impact of MeCP2 on Hif1a. MeCP2 might directly control Hif1a mRNA expression levels in a down-regulating manner. Because MeCP2 does not exist in the genome of $M e c p 2^{-/ y}$ mice, Hif1a might be up-regulated compared to wt mice. 
Secondly, HIF-1a protein levels might not be significantly regulated in $M е с p 2^{-/ y}$ mouse brains due to the discontinuity of hypoxia in $M е с p 2^{-/ y}$ mice. Kron et al. (2011) found out that hypoxia of $M e c p 2^{-1 / y}$ mice is interrupted by short oxygen recovery phases (intermittent hypoxia). During these periods of oxygen recovery the HIF-1a protein structure might be ubiquitinated and degraded, averting the stabilization of the HIF-1a protein.

As discussed above, however, initial experiments were conducted to reassess the results of Fischer et al. (2009). Fischer et al. (2009) conducted protein analysis in the cerebellum and cortex of $M e c p 2^{-1 y}$ mice using western blot technique. The $M е с p 2^{-1 / y}$ mice expression levels were compared to wt mice at the age of P38-60. Significantly higher HIF-1 $\alpha$ levels were revealed in the $M е с p 2^{-/ y}$ brain parts tested.

Reasons, which might explain the differing outcomes of both experiments, are as follows. They are roughly concentrated around the age, the gene expression levels, as well as the living conditions of the mice used.

Age of the mice used: Fischer et al. (2009) tested mice with an age of P38 to P60. Since RTT is a developmental disease that displays different symptoms at different developmental stages, the validity of results, which are based on animals of such a wide rage of age is questionable. Additionally, despite differing estimations of the mean age of death of Mecp2-1/ mice (e.g. P54 (Guy et al. 2001) or P65 (Ward et al. 2011)), the possibility exists that in the study of Fischer et al. (2009) mice older than P45 displayed hypoxia caused by pre-final breathing (Viemari et al. 2005) instead of true RTT breathing symptoms. Fischer et al. (2009) investigated mice at a developmental age of P38-60, whereas this study examined mice at P40. Younger mice were chosen to avoid the possibility that symptoms of hypoxia are caused by senility instead of RTT itself. Andersen (2003) found that rat brains at P40 correspond with human brains of adolescents. Furthermore, Julu et al. (2001) found that Rett patients show a strong manifestation of respiratory disorders during adolescence. It was thus expected that breathing imbalances of $M e c p 2^{-/ y}$ mice compared to wt mice at the age of P40 could be identified. Finally, however, it could also be argued that the age of the mice tested in the experiments of this study were too young. It is possible that P40 represents a too early developmental stage to detect cerebral hypoxia in $M e c p 2^{-/ y}$ mice compared to wt mice. 
Gene expression levels of the mice used: For the experiments of this study, only homozygous $M c p 2^{-1 y}$ mice were chosen to obtain a homogeneous genome of mice. Heterozygous $\mathrm{Mecp}^{+/-}$mice were not included in the experiments in order to avoid differing Mecp2 gene expression levels. Nevertheless, these $M e c p 2^{-/ y}$ mice display a differing phenotype among each other, e.g. due to size differences.

Living conditions of the mice used: The development of mice depends, for example, on the number of littermates in a cage. Non-mutant mice might identify Mecp2-/y mice and isolate them. This leads to higher stress levels of $M e c p 2^{-/ y}$ mice. Stress levels of mammals correlate with methylated DNA levels (Unternaehrer et al. 2012). Methylated DNA is specifically bound by MeCP2 (Nan et al. 1993, see section 1.1.2 The transcription factor MeCP2). i.e. stress levels of mammals correlate with the MeCP2 function. Therefore, it is conceivable that $M e c p 2^{-/ y}$ mice develop differently, although they are of the same genotype. Several characteristics related to the phenotype and even gene expression levels could deviate.

\subsection{The Trh system}

\subsubsection{Trh system expression in wt mice}

Summarizing the above results, significant evidence for breathing-induced hypoxia in $M e c p 2^{-/ y}$ mice at P40 is still missing. Although Fischer et al. (2009) found cerebral hypoxia at later age of development, breathing-induced hypoxia could not yet be identified by this study's experiments. Nevertheless, it is indisputable that respiratory disorders in Rett mouse models exist (Zanella et al. 2008, Ren et al. 2012, Ramirez et al. 2013).

Breathing phenotype in human Rett patients and $M e c p 2^{-/ y}$ mice differs strongly:

It has been demonstrated that in humans breath holding (Julu et al. 2001), hyperventilation (Ren et al. 2012), and hypoventilation (Hagebeuk et al. 2012) leads to a decrease of blood oxygen saturation of at least $50 \%$ (Southall et al. 1988) and to apnea that lasts longer than 45 seconds and induces sudden death (Glaze 2005). Hyper- and hypoventilation, leading to an apneusis (Ren et al. 2012), has been identified in $M e c p 2^{-/ y}$ mice as well (Ramirez et al. 2013). However, a decrease of oxygen saturation could not be demonstrated in $M e c p 2^{-1 y}$ mice yet. Because the metabolism of larger mammals works much slower than the metabolism of smaller 
mammals, it is very likely that apneas, which last approximately 45 seconds, are not demonstrable in $\mathrm{Mecp}^{-/ y}$ mice anyway.

Moreover, another possible reason for the presented results is the existence of a potent counter-regulating gene, which prevents $M e c p 2^{-1 /}$ mice from hypoxic conditions and therefor leads to a modulation of breathing.

To analyze possible reasons more closely, additional experiments were carried out.

These experiments were set up to find a particular counteracting gene that helps $M e c p 2^{-y y}$ mice to adapt their general breathing patterns to respiratory irregularities. Finding such a counteracting gene would help to explain why hypoxia could not be identified in $M e c p 2^{-1 y}$ mice although respiratory disorders evidently exist. Consequently, hypothesis 4 was created:

Hypothesis 4: If there are no indicators for hypoxia in breathing impaired Mecp- $2^{-y}$ mice, a counter-regulator of the breathing impairment exists.

When compared to wt mice, $M e c p 2^{-/ y}$ mice exhibit a phenotype characterized by small size, low weight, and exsiccosis (see section 1.1.3 The mouse model of Rett syndrome), it was suggested that a metabolism-affecting hormone could be dysregulated in $\mathrm{Mecp2}^{-/ y}$ mice in comparison to wt mice. Various metabolismaffecting hormones exist, one of which is TRH.

TRH is a tripeptidal releasing hormone (Boler et al. 1969) that is produced within the hypothalamus area by stimulation of e.g. serotonin (Burgus et al. 1969, Chen and Ramirez, 1980). The release of TRH is stimulated by several energy-demanding processes of the body e.g. low body temperature (Arancibia et al. 1983). The release of TRH triggers secretion of other hormones, such as prolactin and TSH (thyroid-stimulating hormone) from anterior pituitary (Bowers et al. 1971) (Figure 5.1). TRH is known to be widely distributed throughout the brain (Shibusawa et al. 2008) and primarily to influence the growth (Martial et al. 1977) and metabolism (Arancibia et al. 1996) of mammals. Moreover TRH has been identified as a potent neuromodulator (Zhang and van den Pol 2012) to affect rhythm generation of breathing (Manzke 2013).

Several studies have proven the impact of TRH on the augmentation of frequency and the depth-elevation of breathing (Hedner et al. 1983; Bennett et al. 1988; 
Cream et al. 1999; Hou et al. 2012). Cream et al. (1997) discovered that TRH injections in the pre-Bötzinger region of neonatal rats immediately cause an acceleration of the breathing frequency.

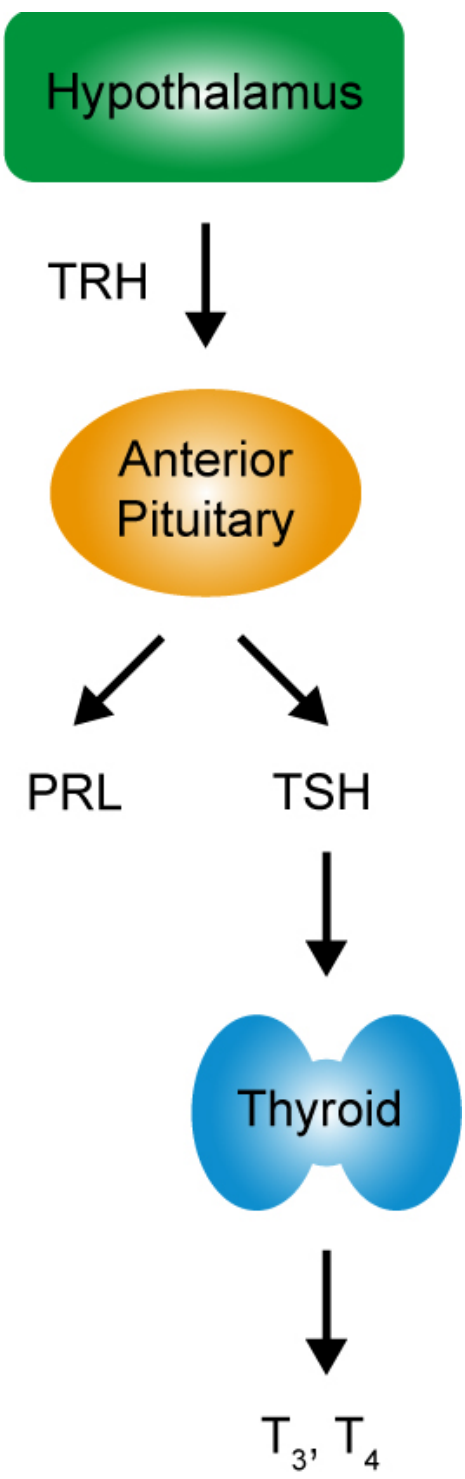

Figure 5.1 Mechanisms of TRH

After being synthetized by hypothalamic neurons (Burgus et al. 1969), TRH reaches the anterior pituitary and causes prolactin and TSH secretion (Bowers et al. 1971). TSH stimulates the thyroid gland, which then releases $T_{3}$ and $T_{4}$. As a consequence, the whole body metabolism gets activated (model adapted from Hinkle et al. 2012). Abbreviations: thyrotropin-releasing hormone (TRH), prolactin $(P R L)$, thyroid-stimulating hormone $(T S H)$, triiodothyronine $\left(T_{3}\right)$, thyroxine $\left(T_{4}\right)$

The first experiment investigated whether Trh expression levels correlate with the expression levels of its receptors. For this reason the Trh mRNA expression levels were measured quantitatively in five different brain areas of wt mice. By using the same procedure, the general regulations of the Trh receptor subtypes 1 and 2 were 
measured in the same five different brain areas. The results of the brain areas hypothalamus and VRC were suggested to be of special interest for this study: The results of the hypothalamic area were analyzed, as this is the area where Trh synthesis takes place. Because the VRC represents the breathing-related area of the brain, the results of its experiments were particularly interesting.

The results revealed that Trh is ubiquitously expressed throughout the brain although it is solely produced within the hypothalamus and next affects hormones within anterior pituitary. In the hypothalamus region the second highest expression levels in wt mice concerning all three parts of the Trh system (the Trh hormone itself and its 2 receptor subtypes) were found. Although the experiment did not identify the highest expression levels in the hypothalamic area, the results are as expected. As implied above, it was expected that the hypothalamic area would show the highest Trh expression levels of all brain areas, since Trh is synthesized in this brain area.

Nevertheless, the highest Trh expression levels were found in the inferior olive, which is related to the coordination and motor area of the brain (Kawato and Gomi, 1992). Compared to the cerebellum area, the inferior olive demonstrated a 700 -fold expression level of Trh.

Although high Trh, Trh-r1 and Trh-r2 expression levels were expected in the VRC area as well, the experiments revealed low levels in this brain area. This result could be linked to two different reasons: Firstly, Trh might not play an as important role in the VRC area as suggested, contradicting the assumption that Trh prevents hypoxic conditions, e.g. damages caused by breathing impairment. Secondly, Trh expression levels do not need to be particularly high to prevent hypoxic conditions. Slight variations of Trh might already lead to major consequences when basal Trh concentration levels are low.

\subsubsection{The systemic Trh expression is modified in the brain}

To investigate $T r h$ mRNA levels of $M e c p 2^{-/ y}$ mice compared to wt mice in five brain areas, a further qRT-PCR experiment was conducted. Experiments analyzing the Trh receptor subtypes 1 and 2 were also conducted following the same procedure. 
It was found that the Trh expression levels of $M e c p 2^{-1 y}$ mice compared to wt mice were significantly up-regulated within the cortex, hypothalamus and VRC. When comparing Trh receptors expression levels of wt and $M e c p 2^{-1 y}$ mice no significant regulation could be found.

The up-regulation of $T r h$ in $M e c p 2^{-1 y}$ mice compared to wt mice might be explained by various reasons.

(1) It is possible, for example, that MeCP2 directly controls the Trh expression levels. Because the depressing impact of MeCP2 on Trh synthesis is missing, Trh expression levels might be up-regulated in $M e c p 2^{-1 y}$ mice when compared to wt mice. (2) It could be possible that high Trh levels in $M e c p 2^{-1 / y}$ mice compared to wt mice exist due to the negative feedback mechanism of non-detectable Mecp2. According to Yano and Lou (2004) Trh controls the gene expression of Mecp2. Because in Mecp2 ${ }^{-1 / y}$ mice Mecp2 gene and MeCP2 protein do not exist, it is thinkable, that Trh reacts to this condition by elevating its own prevalence. (3) It is possible that high $T r h$ levels in Meсp2-1/ mice compared to wt mice exist due to its function as a natural pain relief. It was found that higher Trh levels result in pain relief (Chizh and Headley 1995), sleep deprivation (Zhang and van den Pol 2012), and loss of appetite (Suzuki et al. 1982). It is possible that Trh levels increase since $M e c p 2^{-/ y}$ mice suffer under pain, for example, caused by spasticity and seizures. Increased Trh expression levels might also explain the lack of sleep and appetite and impacts negatively on the animals' vitality and body size. Decreased vitality and body size are a common characteristic of $M e c p 2^{-1 y}$ mice (Guy et al. 2001). (4) It could be possible that high Trh levels in Mecp2-ly mice compared to wt mice exist due to the energy requiring symptoms of RTT, which trigger Trh release. It has been found that energy-demanding processes of the body, such as hyperventilation (Mount et al. 2003), weakness, cachexia, and spasticity (Hagberg and Witt-Engerström 1986) lead to an increase of Trh expression levels (Arancibia et al. 1983). Under these circumstances primarily physiological dysregulations such as lower body weight and smaller body size would become visible on a molecular level. (5) It is possible that high Trh levels in $M e c p 2^{-1 y}$ mice compared to wt mice exist due to impaired breathing in $M e c p 2^{-/ y}$ mice. Trh might function as a modulator of adaption, induced by respiratory imbalances in $M_{\text {ecp }}{ }^{-/ y}$ mice compared to wt mice. 
All of the described conditions, no matter if they occur separately or together lead to an adaption process of Trh:

The adaption process begins with an up-regulation of Trh; the up-regulation of Trh modifies the breathing of $M e c p 2^{-/ y}$ mice; and the modification of the breathing of $M e c p 2^{-/ y}$ mice averts hypoxia. The adaption process is illustrated in Figure 5.2.

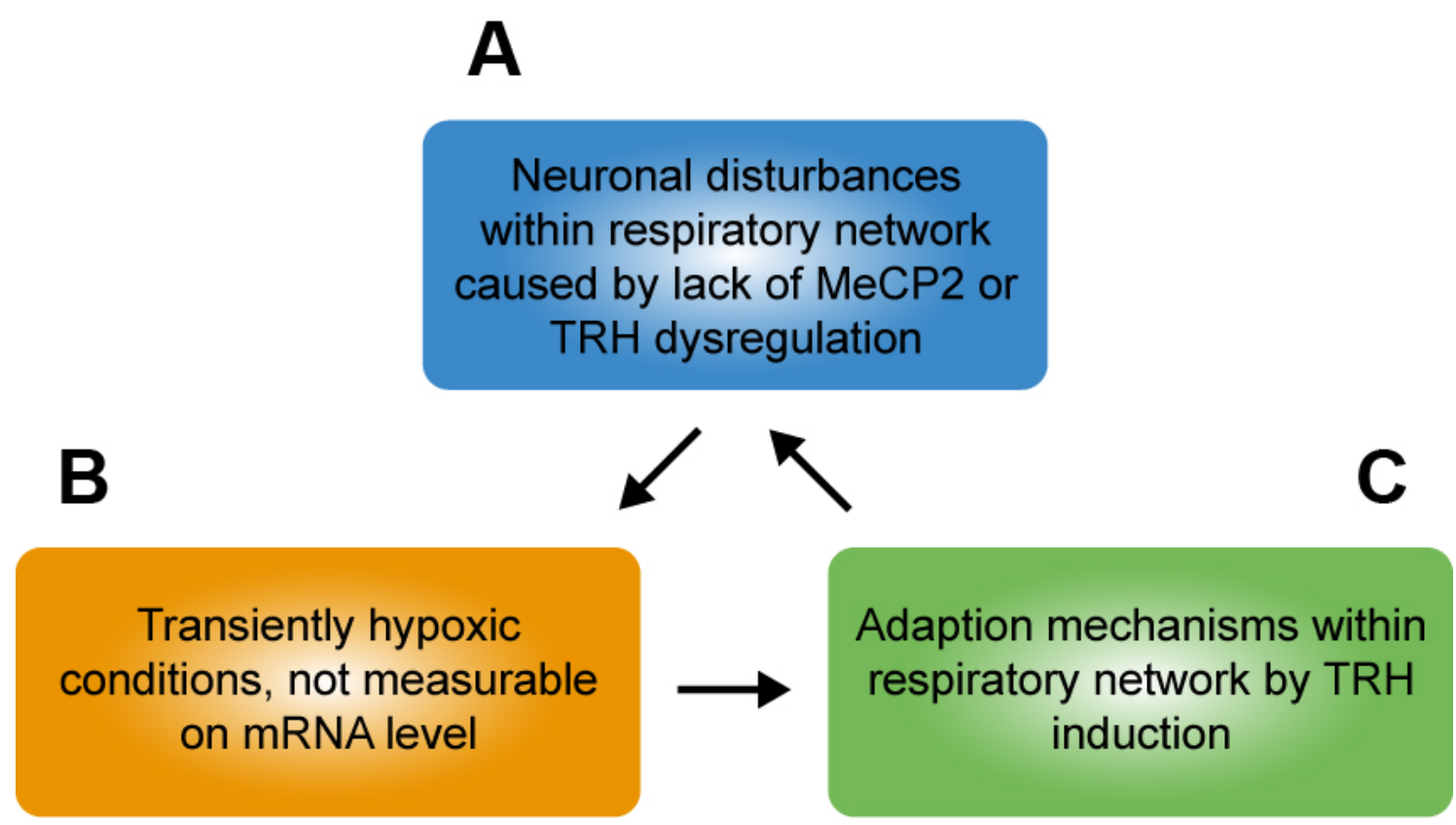

Figure 5.2 TRH adaption process during hypoxia within the brain of $M e c p 2^{-/ y}$ mice

(A) MeCP2 is lacking in Mecp2 $2^{-1 y}$ mice. This induces a TRH dysregulation and leads to various deregulated gene transcriptions. (B) The imbalance within the respiratory network causes a phenotype of breathing irregularities. However, these breathing irregularities cannot be identified on elevated hypoxia indicating gene levels. (C) Breathing irregularities cannot be identified on hypoxic gene level, because Trh stimulates the breathing frequency. Trh expression levels have been demonstrated to be significantly up-regulated within several brain areas of $M e c p 2^{-1 y}$ mice. These elevated Trh expression levels lead to imbalances within the neuronal network, suppressing an effect on hypoxic gene level.

Both the results and the above discussion of the results substantiate the relation between lack of MeCP2 and upregulation of Trh. Consequently, the reason for missing indicators of hypoxia in $M e c p 2^{-/ y}$ mice in spite of impaired breathing is Trh, which functions as a counter-regulator of the breathing impairment.

\subsection{Further research}

This study has demonstrated that $M e c p 2^{-/ y}$ mice at the age of P40 do not show any hypoxic signs on protein or mRNA level, such as elevated HIF protein levels. Therefore, this study suggests that Trh induces an adaption process as a reaction to breathing disorders, which leads to a modulation of breathing within the 
respiratory network of $M e c p 2^{-/ y}$ mice. Strong indicators have been presented that an induction of hypoxic genes is prevented by a deeper as well as accelerated respiration. In other words, although the $M e c p 2^{-/ y}$ mice phenotype indubitably demonstrates breathing imbalances compared to wt mice, these disruptions cannot be detected at the genetic level.

Although breathing disorders are similar in human beings, they cannot be regarded as the same. The main differences between the respiratory phenotype of $M e c p 2^{-1 y}$ mice and humans reside in breathing frequency and amplitude: Human RTT patients exhibit irregular periods of hypo- and hyperventilation. Additionally, hypoventilation duration of RTT patients last in some cases more than 45 seconds and can be described as breath holding. This irregular respiratory rhythm can be

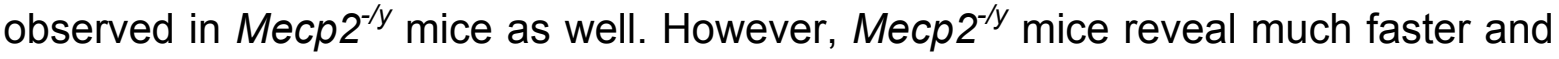
irregular breathing patterns and lack the relatively long lasting apneas (Ramirez et al. 2013). It is thus impossible to transfer the suggested animal model without any adaptation to human Rett patients. Due to these differences, it would be of special interest to investigate the role of Trh in the respiratory phenotype of human RTT patients further.

This study analyzed mice at the age of P40, it is thus problematic to simply transfer the findings to mice at an older age. Further studies analyzing older $M e c p 2^{-/ y}$ mice, which are rare because of restricted life-span, would be particularly interesting in order to possibly generalize the results. It should be emphasized again that $\mathrm{Mecp2}^{-1 /}$ mice at P40 were chosen precisely because they display very similar - if not the same - RTT symptoms as human RTT patients (Ren et al. 2012). Furthermore, Rett symptoms in human RTT patients are strongly pronounced at an age between five to ten years (Julu et al. 2001) and the corresponding age of mice at P40 in human RTT patients is 13 to 19 years (Anderson, 2003), which further justifies the sample's age chosen. Most importantly however, it would be interesting to see, whether Trh expression levels decrease with advancing age. A decrease of Trh expression levels with higher age (e.g. at P50) would confirm this study's results and help to further explain the underlying reasons for the differing findings of Fischer et al. (2009).

As noted above (see section 5.4.1 Trh system expression in wt mice), injecting TRH in the neonatal rat brain leads to a stimulation of breathing immediately (Cream et 
al. 1997). It would be necessary to analyze the effect of TRH injected into the brain of wt as well as $M e c p 2^{-/ y}$ mice in order to find out whether similar effects can be observed. Controlling the cerebral TRH levels with the aid of pharmacological injections might lead to a weakening of RTT symptoms in $M e c p 2^{-1 y}$ mice. Although TRH influences breathing in mice just like TRH in humans (Rekling et al. 1996, Nink et al. 2008), experiments analyzing the Trh expression levels of human RTT patients are still missing. It would be highly informative to see, whether Trh expression levels are down-regulated in human RTT patients, who display severe hypoxia. Going further, it would be also of interest to investigate, whether breathing impairments in human RTT patients are correlated with Trh expression levels. As with $M e c p 2^{-/ y}$ mice, controlling the cerebral TRH levels with the aid of pharmacological injections might lead to a weakening of symptoms in human RTT patients. 


\section{Conclusion}

The respiratory phenotype of $M e c p 2^{-/ y}$ mice at postnatal day 40 is characterized by arrhythmia, breath holdings and apneas. A previous study has indicated that these respiratory disturbances lead to hypoxia in $M e c p 2^{-/ y}$ mice at the age of P38-60.

However, this study has found out that respiratory disorders of $M e c p 2^{-/ y}$ mice (P40) do not provoke an induction of hypoxia genes at all. 84 genes were examined by conducting a $R T^{2}$ Profiler PCR Array: Hypoxia Signaling Pathway in the VRC. This region contains important parts of the medullary respiratory network, which are essential for rhythm generation. None of the analyzed genes were found to be upregulated. Additionally, gene levels of specific hypoxia related genes were compared between wt and $M e c p 2^{-/ y}$ mice in the same brain regions. It was found that none of the eight genes displayed altered regulation. Finally, Hif1a mRNA levels of $M e c p 2^{-/ y}$ mice were compared to wt mice, conducting a qRT-PCR within five brain areas. The final experiments were carried out to reassess a specific study, which tested HIF-1 a protein expression levels and additionally found hypoxia in $M e c p 2^{-/ y}$ mice. Four brain areas of the $M e c p 2^{-/ y}$ mice showed increased Hif1a gene levels. However, these results could not be confirmed at the protein level.

To explain the absence of hypoxia it was demonstrated that in $M e c p 2^{-/ y}$ mice Trh was strongly up-regulated in VRC. Within the VRC, which contains major parts of the respiratory network that are important for the rhythm generation, Trh serves as a neuromodulator increasing breathing frequency. Indeed, Mecp $2^{-/ y}$ mice at P40 show an increased breathing frequency in general. Therefore, up-regulation of Trh might be a potential mechanism in Mecp $2^{-/ y}$ mice to circumvent hypoxia in the early phase of disturbed breathing. The up-regulation of Trh in further analyzed brain regions might also explain the typical emaciated phenotype of $M e c p 2^{-/ y}$ mice. It is important to analyze whether this adaption mechanism is also present at postnatal stages >P50 in additional experiments.

Investigating the effects of TRH injections on hypoxia symptoms in $M e c p 2^{-/ y}$ mice but more importantly in human RTT patients is suggested for further research. 


\section{References}

\section{References}

Amir RE, Van den Veyver IB, Wan M, Tran CQ, Francke U, Zoghbi HY (1999): Rett syndrome is caused by mutations in X-linked MECP2, encoding methyl-CpG-binding protein 2. Nat Genet 23(2), 185-8

Andersen SL (2003): Trajectories of brain development: point of vulnerability or window of opportunity? Neurosci Biobehav Rev 27, 3-18

Arancibia S, Tapla-Arancibia L, Assenmacher I, Astier H (1983): Direct evidence of short-term coldinduced TRH release in the median eminence of unanesthetized rats. Neuroendocrinology $\underline{37}, 225-8$

Arancibia S, Rage F, Astier H, Tapia-Arancibia L (1996): Neuroendocrine and autonomous mechanisms underlying thermoregulation in cold environment. Neuroendocrinology 64(4), 257-67

Balis UJ, Morris KF, Koleski J, Lindsey BG (1993): Simulations of a ventrolateral medullary neural network for respiratory rhythmogenesis inferred from spike train cross-correlation. Biol Cybern $\underline{70}$, $311-27$

Barlow DP (1994): Imprinting: a gamete's point of view. Trends Genet 10(6), 194-9

Beilharz EJ, Russo VC, Butler G, Baker NL, Connor B, Sirimanne ES, Dragunow M, Werther GA, Gluckman PD, Williams CE (1998): Co-ordinated and cellular specific induction of the components of the IGF/IGFBP axis in the rat brain following hypoxic-ischemic injury. Mol Brain Res 59(2), 119-34

Bennett L, Gluckman PD, Johnston BM (1988): The central effects of Thyrotropin-releasing hormone on the breathing movements and electrocortical activity of the fetal sheep. Pediatr Res 23(1), 72-5

Boler J, Enzmann F, Folkers K (1969): The identity of chemical and hormonal properties of the Thyrotropin releasing hormone and Proglutamyl-Histidyl-Proline amide. Biochem Bioph Res Co 37(4), 705-10

Bowers CY, Friesen HG, Hwang P, Guyda HJ, Folkers K (1971): Prolactin and thyrotropin release in man by synthetic Pyroglutamyl-Histidyl-Prolinamide. Biochem Bioph Res Co 45(4), 1033-41

Burgus R, Dunn TF, Desiderio D, Guillemin R (1969): Molecular structure of the hypothalamic hypophysiotropic TRF factor of ovine origin: mass spectrometry demonstration of the PCA-His-ProNH2 sequence. C R Acad Sci 269(19), 1870-3

Cervós-Navarro J, Diemer NH (1991): Selective vulnerability in brain hypoxia. Crit Rev Neurobiol 6(3), 149-82

Chahrour M, Jung SY, Shaw C, Zhou X, Wong STC, Qin J, Zoghbi HY (2008): MeCP2, a key contributor to neurological disease, activates and represses transcription. Science $320,1224-9$ 


\section{References}

Chan DA, Giaccia AJ (2007): Hypoxia, gene expression, and metastasis. Cancer Metast Rev 26(2), $333-9$

Chao HT, Zoghbi HY, Rosenmund C (2007): MeCP2 controls excitatory synaptic strength by regulating glutamatergic synapse number. Neuron $\underline{56(1)}, 58-65$

Chávez JC, Pichiule P, Boero J, Arregui A (1995): Reduced mitochondrial respiration in mouse cerebral cortex during chronic hypoxia. Neurosci Lett 193, 169-72

Chen RZ, Akbarian S, Tudor M, Jaenisch R (2001): Deficiency of methyl-CpG binding protein-2 in CNS neurons results in a Rett-like phenotype in mice. Nat Genet 27(3), 327-31

Chen WG, Chang Q, Lin Y, Meissner A, West AE, Griffith EC, Jaenisch R, Greenberg ME (2003): Derepression of BDNF transcription involves calcium-dependent phosphorylation of MeCP2. Science $\underline{302}, 885-9$

Chen YF, Ramirez VD (1980): Serotonin stimulates thyrotropin-releasing hormone release from superfused rat hypothalamic. Endocrinology 108(6), 2359-66

Chizh BA, Headley PM (1995): Thyrotropin-releasing hormone facilitates spinal nociceptive responses by potentiating NMDA receptor-mediated transmission. Eur J Pharmacol $\underline{300}, 183-9$

Clark RS, Kochanek PM, Chen M, Watkins SC, Marion DW, Chen J, Hamilton RL, Loeffert JE, Graham $\mathrm{SH}$ (1999): Increases in Bcl-2 and cleavage of caspase-1 and caspase-3 in human brain after head injury. FASEB J 13(8), 813-21

Clarke E, O'Malley CD (1996): The human brain and spinal cord: a historical study illustrated by writings. Second edition; Norman neurosciences, Novato 1999

Cotes JE, Chinn DJ, Miller MR (2006): Lung Function: physiology, measurement and application in medicine. Sixth edition; Blackwell publishing, Malden 2006

Courten-Myers GM, Yamaguchi S, Wagner KR, Ting P, Myers RE (1985): Brain injury from marked hypoxia in cats: role of hypotension and hyperglycemia. J Am Heart Assoc 16, 1016-21

Cream CL, Li A, Nattie EE (1997): RTN TRH causes prolonged respiratory stimulation. J Appl Physiol 83, $792-9$

Cream C, Nattie E, Li A (1999): TRH microdialysis into the RTN oft he conscious rat increases breathing, metabolism, and temperature. J Appl Physiol $\underline{87}$, 792-9

Damert A, Ikeda E, Risau W (1997): Activator-protein-1 binding potentiates the hypoxia-inducible factor1-mediated hypoxia-induces transcriptional activation of vascular-endothelial growth factor expression in C6 glioma cells. Biochem J 327, 419-23 


\section{References}

D’Esposito M, Quaderi NA, Ciccodicola A, Bruni P, Esposito T, D’Urso M, Brown SD (1996): Isolation, physical mapping, and northern analysis of the X-linked human gene encoding methyl CpG-binding protein, MECP2. Mamm Genome 7(7), 533-5

D'Orsi G, Demaio V, Scarpelli F, Calvario T, Minervini MG (2009): Central sleep apnoea in Rett syndrome. J Neurol Sci $\underline{30}$, 389-91

Ehrenreich H, Stühmer W: From synaptopathies to system dysfunction. Poster presented in Göttingen

Ebert BL, Bunn HF (1999): Regulation of the erythropoietin gene. Blood 94(6), 1864-77

Falini A, Barkovich AJ, Calabrese G, Origgi D, Triulzi F, Scotti G (1998): Progressive brain failure after diffuse hypoxic ischemic brain injury: A serial MR and proton MR spectroscopic study. Am J Neuroradiol $19,648-52$

Feldmann JL, Del Negro CA (2006): Looking for inspiration: new perspectives on respiratory rhythm. Nat Rev Neurosci 7(3), 1-25

Feldmann JL, Mc Crimmon D (2008): Fundamental Neuroscience. San Diego Academic Press $\underline{2008}$, $855-72$

Fink SL, Cookson BT (2005): Apoptosis, pyroptosis, and necrosis: Mechanistic description of dead and dying eukaryotic cells. Infect Immun 73(4), 1907-16

Firth JD, Ebert BL, Ratcliffe PJ (1995): Hypoxic regulation of lactate dehydrogenase A: interaction between hypoxia-inducible factor 1 and cAMP response elements. J Biol Chem 270(36), 21021-27

Fischer M, Reuter J, Gerich FJ, Hildebrandt B, Hägele S, Katschinski D, Müller M (2009): Enhanced hypoxia susceptibility in hippocampal slices from a mouse model of Rett syndrome. J Neurophysiol 101(2), 1016-32

Fuertes-González MC, Silvestre FJ, Almerich-Silla JM (2011): Oral findings in Rett syndrome: a systemic review of the dental literature. Med Oral Patol Oral Cir Bucal 16(1), 37-41

Fuster (2008): The prefrontal cortex. Fourth edition; Elsevier, Amsterdam 2008

Gadalla KK, Bailey ME, Cobb SR (2011): MeCP2 and Rett syndrome: reversibility and potential avenues for therapy. Biochem J 439(1), 1-14

Glaze DG (2005): Neurophysiology of Rett syndrome. J Child Neurol 20(9), 740-6

Glaze DG, Schultz RJ, Frost JD (1998): Rett syndrome: characterization of seizures versus nonseizures. Electroen Clin Neuro 106(1), 79-83

Gökben S, Ardic ÜA, Serdaroglu G (2012): Use of buspirone and fluoxetine for breathing problems in Rett syndrome. Pediatr Neurol $\underline{46}, 192-94$ 


\section{References}

Gonzales ML, Adams S, Dunaway KW, Lasalle JM (2012): Phosphorylation of distinct sites in MeCP2 modifies cofactor associations and the dynamics of transcriptional regulation. Mol Cell Biol $\underline{32(14)}$, 2894-903

Guy J, Hendrich B, Holmes M, Martin JE, Bird A (2001): A mouse Mecp2-null mutation causes neurological symptoms that mimic Rett syndrome. Nat Genet 27(3), 322-6

Guy J, Gan J, Selfridge J, Cobb S, Bird A (2007): Reversal of neurological defects in a mouse model of Rett syndrome. Science 315(5815), 1143-7

Hagberg B, Witt-Engerström I (1986): Rett syndrome: a suggested staging system for describing impairment profile with increasing age towards adolescence. Am J Med Gen 24, 47-59

Hagberg B, Goutieres F, Hanefeld F, Rett A, Wilson J (1985): Rett syndrome: criteria for inclusion and exclusion. Brain Dev-Jpn 7, 372-3

Hagebeuk EE, Bijlmer RP, Koelman JH, Poll-The BT (2012): Respiratory disturbances in Rett syndrome: don't forget to evaluate upper airway obstruction. J Child Neurol 27(7), 888-92

Halterman MW, Gill M, DeJesus C, Ogihara M, Schor NF, Federoff HW (2010): The endoplasmic reticulum stress response factor $\mathrm{CHOP}-10$ protects against hypoxia-induced neuronal death. $\mathrm{J}$ Biol Chem 285, 21329-40

Han ZA, Jeon HR, Kim SW, Park JY, Chung HJ (2012): Clinical characteristics of children with Rett syndrome. Ann Rehabil Med 36, 334-9

Hanks SB (1986): The role of therapy in Rett syndrome. Am J Med Genet 24, 247-52

Hedner J, Hedner T, Wessberg P, Lundberg D, Jonason J (1983): Effects of TRH and TRH analogues on the central regulation of breathing in the rat. Acta Physiol Scand 117(3), 427-37

Hendrich B, Tweedie S (2003): The methyl-CpG binding domain and the evolving role of DNA methylation in animals. Trends Genet 19(5), 269-77

Hilbi H, Moss JE, Hersh D, Chen Y, Arondel J, Banerjee S, Flavell RA, Yuan J, Sansonetti PJ, Zychlinsky A (1998): Shigella-induced apoptosis is dependent on caspase-1 which binds to IpaB. J Biol Chem 273(49), 32895-9000

Hinkle PM, Gehret AU, Jones BW (2012): Desensitization, trafficking, and resensitization of the pituitary thyrotropin-releasing hormone receptor. Front Neurosci 6(180), 1-14

Hökfeld T, Arvidsson U, Cullheim S, Millhorn D, Nicholas AP, Pieribone V, Seroogy K, Ulfhake B (2000): Multiple messengers in descending serotonin neurons: localization and functional implications. $J$ Chem Neuroanat $18,75-86$ 


\section{References}

Hoffbuhr K, Devaney JM, LaFleur B, Sirianni N, Scacheri C, Giron J, Schuette J, Innis J, Marino M, Philippart M (2001): MeCP2 mutations in children with and without the phenotype of Rett syndrome. Neurology 56(1), 1486-95

Horike S, Cai S, Miyano M, Cheng JF, Kohwi-Shigematsu T (2005): Loss of silent-chromatin looping and impaired imprinting of DLX5 in Rett syndrome. Nat Genet $\underline{37}, 31-40$

Hou L, Zhou X, Chen Y, Qiu D, Zhu L, Wang J (2012): Thyrotropin-releasing hormone causes a tonic excitatory postsynaptic current and inhibits the phasic inspiratory inhibitory inputs in inspiratoryinhibited airway vagal preganglionic neurons. Neuroscience 202, 184-91

Hu CJ, Wang LY, Chodosh LA, Keith B, Simon MC (2003): Differential roles of hypoxia-inducible factor 1 (HIF-1) and HIF-2 in hypoxic gene regulation. Mol Cell Biol 23(24), 9361-74

Huang B, Castillo M (2008): Hypoxic-ischemic brain injury: imaging findings from birth to adulthood. Radiographics 28(2), 417-39

Hughes PE, Alexi T, Walton M, Williams CE, Dragunow M, Clark RG, GLuckman PD (1999) Activity and injury-dependent expression of inducible transcription factors, growth factors and apoptosis-related genes within the central nervous system. Prog Neurobiol 57(4), 421-50

Ishikawa K, Yoshida S, Kadota K, Nakamura T, Niiro H, Arakawa S, Yoshida A, Akashi K, Ishibashi T (2010): Gene Expression Profile of Hyperoxic and Hypoxic Retinas in a Mouse Model of OxygenInduced Retinopathy. Invest Ophth Vis Sci 51, 4307-19

Jin K, Mao XO, Eshoo MW, del Rio G, Rao R, Chen D, Simon RP, Greenberg DA (2002): cDNA microarray analysis of changes in gene expression induced by neuronal hypoxia in vitro. Neurochem Res 27(10), 1105-12

Johnston MV, Trescher WH, Ishida A, Nakajima W (2001): Neurobiology of hypoxic-ischemic injury in the developing brain. Pediatr Res $49(6), 735-41$

Jolly S, Journiac N, Naudet F, Gautheron V, Mariani J, Vernet-der Garabedian B (2011): Cellautonomous and non-cell-autonomous neuroprotective functions of ROR $\alpha$ in neurons and astrocytes during hypoxia. J Neurosci 31(40), 14314-23

Jones PL, Veenstra GJC, Wade PA, Vermaak D, Kass SU, Landsberger N, Strouboulis J, Wolffe AP (1998): Methylated DNA and MeCP2 recruit histone deacetylase to repress transcription. Nat Genet $19,187-91$

Julu PO, Kerr AM, Apartopoulos F, Al-Rawas S, Witt Engerström I, Engerström L, Jamal GA, Hansen S (2001): Characterisation of breathing and associated central autonomic dysfunction in the Rett disorder. Arch Dis Child 85, 29-37 


\section{References}

Katz DM, Dutschmann M, Ramirez JM, Hilaired G (2009): Breathing disorders in Rett syndrome: progressive neurochemical dysfunction in the respiratory network after birth. Resp Physiol Neurobiol $168,1-17$

Kaur C, Sivakumar V, Zou Z, Ling EA (2012): Microglia-derived proinflammatory cytokines tumor necrosis factor-alpha and interleukin-1beta induce Purkinje neuronal apoptosis via their receptors in hypoxic neonatal rat brain. Brain Struct Funct 219(1), 151-70

Kawahara N, Wang Y, Mukasa A, Furuya K, Shimizu T, Hamakubo T, Aburatani H, Kodama T, Kirino T (2004): Genome-wide gene expression analysis for induced ischemic tolerance and delayed neuronal death following transient global ischemia in rats. J Cerebr Blood F Met 24, 212-233

Kawato M, Gomi H (1992): A computational model of four regions of the cerebellum based on feedbackerror learning. Biol Cybern 68, 95-103

Klempt ND, Sirimanne E, Gunn AJ, Klempt M, Singh K, Williams C, Gluckman PD (1992): Hypoxiaischemia induces transforming growth factor beta $1 \mathrm{mRNA}$ in the infant rat brain. Mol Brain Res 13(1-2), 93-101

Korner PI (1959): Circulary adaptations in hypoxia. Physiol Rev 39(4), 687-719

Kriaucionis S, Bird A (2004): The major form of MeCP2 has a novel N-terminus generated by alternative splicing. Nucleic Acids Res 32(5), 1818-23

Kron M, Zimmermann JL, Dutschmann M, Funke F, Müller M (2011): Altered responses of MeCP2deficient mouse brain stem to severe hypoxia. J Neurophysiol $\underline{105}$, 3067-79

Laurvick CL, de Klerk N, Bower C, Christodoulou J, Ravine D, Ellaway C, Williamson S, Leonhard H (2006): Rett syndrome in Australia: a review of the epidemiology. J Pediatr 148(3), 347-52

Lee W-H, Wang G-M, Yang X-L, Seaman LB, Vannucci SI (1999): Perinatal hypoxia-ischemia decreased neuronal but increased cerebral vascular endothelial IGFBP3 expression. Endocrine 11(2), 181-8

Li E (2002): Chromatin modification and epigenetic reprogramming in mammalian development. Nat Rev Genet $\underline{3}, 662-73$

Lowry OH, Rosebrough NJ, Farr AL, Randall RJ (1951): Protein measurement with the Folin phenol reagent. J Biol Chem, 193(1), 265-75

Luigetti M, Goldsberry GT, Cianfoni A (2012): Brain MRI in global hypoxia-ischemia: a map of selective vulnerability. Acta Neurol Belg 112, 105-107

Lusardi TA, Farr CD, Faulkner LC, Pignataro G, Yang T, Lan J, Simon RP, Saugstad JA (2009): Ischemic preconditioning regulates expression of microRNAs and a predicted target, MeCP2, in mouse cortex. J Cerebr Blood F Met 30, 744-56 


\section{References}

Maclean DB, Jackson IMD (1988): Molecular biology and regulation of the hypothalamic hormones. Baillière Clin Endoc 2(4), 835-68

Maezawa I, Jin L-W (2010): Rett syndrome microglia damage dendrites and synapses by the elevated release of glutamate. J Neurosci $\underline{30(15)}$, 5346-56

Mandrioli M (2007): A new synthesis in epigenetics: towards a unified function of DNA methylation from invertebrates to vertebrates. Cell Mol Life Sci 64 , 2522-4

Manzke T: Serotonin receptor-induced reversal of opioid-mediated respiratory depression. Med. Habil.Schr. Göttingen 2013

Martial JA, Baxter JD, Goodman HM, Seeburg PH (1977): Regulation of growth hormone messenger RNA by thyroid and glucocorticoid hormones. Proc Natl Acad Sci $\underline{74}, 1816-20$

Martinowich K, Hattori D, Wu H, Fouse S, He F, Hu Y, Fan G, Sun YE (2003): DNA methylation-related chromatin remodeling in activity dependent BDNF gene regulation. Science $\underline{302}, 890-3$

Matsugu M, Duffin J, Poon CS (1998): Entrainment, instability, quasi-periodicity, and chaos in a compound neural oscillator. J Comput Neurosci $\underline{5}, 35-51$

Mellén M, Ayata P, Dewell S, Kriaucionis S, Heintz N (2012): MeCP2 binds to 5hmC enriched within active genes and accessible chromatin in the nervous system. Cell $151,1417-30$

Mironov SL, Skorova E, Hartelt N, Mironova LA, Hasan MT, Kügler S (2009): Remodelling of the respiratory network in a mouse model of Rett syndrome depends on brain-derived neurotrophic factor regulated slow calcium buffering. J Physiol 587(11), 2473-85

Mnatzakanian GN, Lohi H, Munteanu I, Alfred SE, Yamada T, MacLeod PJM, Jones JR, Scherer SW, Schanen NC, Friez MJ (2004): A previously unidentified MECP2 open reading frame defines a new protein isoform relevant to Rett syndrome. Nat Genet 36(4), 339-41

Morani A, Barros RPA, Imamov O, Huttenby K, Amer A, Warner M, Gustafsson JA (2006): Lung dysfunction causes systemic hypoxia in estrogen receptor $\beta$ knockout $\left(E R \beta^{-/}\right)$mice. Proc Natl Acad Sci 103(18), 7165-9

Morton RE, Pinnington L, Ellis RE (2000): Air swallowing in Rett syndrome. Dev Med Child Neurol 42 , $271-5$

Mount R, Charman T, Hastings RP, Reilly S, Cass H (2003): Features of autism in Rett syndrome and severe mental retardation. J Autism Dev Disord 33(4), 435-42

Nan X, Meehan RR, Bird A (1993): Dissection of the methyl-CpG binding domain from the chromosomal protein MeCP2. Nucleic Acids Res 21(21), 4886-92 


\section{References}

Nan X, Campoy FJ, Bird A (1997): MeCP2 is a transcriptional repressor with abundant binding sites in genomic chromatin. Cell $88(4), 471-81$

Nicholson DW, Thornberry NA (1997): Caspases: Killer proteases. Trends Biochem Sci 22, 299-306

Nink M, Krause U, Lehnert H, Heuberger W, Huber I, Schulz R, Hommel G, Beyer J (2008): Thyrotropin-releasing hormone has stimulatory effects on ventilation in humans. Acta Physiol Scand 141(3), 309-18

Oddy WH, Webb KG, Baikie G, Thompson SM, Reilly S, Fyfe SD, Young D, Anderson AM, Leonard H (2007): Feeding experiences and growth status in a Rett syndrome population. J Pediatr Gastr Nutr 45, $582-90$

Ogier M, Wang H, Hong E, Wang Q, Greenberg ME, Katz DM (2007): Brain-derived neurotrophic factor expression and respiratory function improve after ampakine treatment in a mouse model of Rett syndrome. J Neurosci 27(40), 10912-17

Ogilvie MD, Gottschalk A, Anders K, Richter DW, Pack Al (1992): A network model of respiratory rhythmogenesis. Am J Physiol 263, R962-75

Panigrahy A, White WF, Rava LA, Kinney HC (1995): Developmental changes in [3H]kainite binding in human brainstem sites vulnerable to perinatal hypoxia-ischemia. Neuroscience $\underline{67(2)}$, 441-54

Paxinos G, Franklin KBJ: Paxinos and Franklin's the mouse brain in stereotaxic coordinates. Second edition; Academic Press, San Diego 2001

Peyssonnaux C, Zinkernagel AS, Schuepbach RA, Rankin E, Vaulont S, Haase VH, Nizet V, Johnson RS (2007): Regulation of iron homeostasis by the hypoxia-inducible transcription factors (HIFs). J Clin Invest 117(7), 1926-32

Pfaffl MW (2001): A new mathematical model for relative quantification in real-time RT-PCR. Nucleic Acids Res, 29(9), e45

Pugh CW, Ratcliffe PJ (2003): Regulation of angiogenesis by hypoxia: Role of the HIF system. Nat Med $9(6), 677-84$

Quaderi NA, Meehan RR, Tate PH, Cross SH, Bird AP, Chatterjee A, Herman GE, Brown SD (1994): Genetic and physical mapping of a gene encoding a methyl CpG binding protein, Mecp2, to the mouse X chromosome. Genomics 22(3), 648-51

Ragel BT, Couldwell WT, Gillespie DL, Jensen RL (2007): Identification of hypoxia-induced genes in a malignant glioma cell line (U-251) by cDNA microarray analysis. Neurosurg Rev 30(3), 181-7

Ramirez JM, Ward CS, Neul JL (2013): Breathing challenges in Rett syndrome: lesson learned from humans and animal models. Respiratory Physiol Neurobi, in press, available online 28 june 2013 


\section{References}

Rekling JC, Champagnat J, Denavit-Saubie M (1996): Thyrotropin-releasing hormone (TRH) depolarizes a subset of inspiratory neurons in the newborn mouse brain stem in vitro. J Neurophysiol 75(2), 811-9

Ren J, Ding X, Funk GR, Greer JJ (2012): Anxiety-related mechanisms of respiratory dysfunction in a mouse model of Rett syndrome. J Neurosci 32(48), 17230-40

Rett A (1966). On a unusual brain atrophy syndrome in hyperammonemia in childhood. Wien Med Wochenschr (1946), 116(37), 723-6

Richter DW (1982): Generation and maintenance of the respiratory rhythm. J Exp Biol 100, 93-107

Richter DW, Ballanyi K, Schwarzacher S (1992): Mechanisms of respiratory rhythm generation. Neurobiology 1992(2), 788-93

Richter DW, Pierrefiche O, Lalley PM, Polder HR (1996): Voltage-clamp analysis of neurons within deep layers of the brain. J Neurosci Meth, $\underline{67(2)}, 121-3$

Rohdin M, Fernell E, Eriksson M, Albage M, Lagercrantz H, Katz-Salamon M (2007): Disturbances in cardiorespiratory function during day and night in Rett syndrome. Pediatr Neurol 37(5), 338-44

Rolfs A, Kvietikova I, Gassmann M, Wenger RH (1997): Oxygen-regulated transferrin expression is mediated by hypoxia-inducible factor-1. J Biol Chem 272(32), 20055-62

Russell JC, Blue ME, Johnston MV, Naidu S, Hossain MA (2007): Enhanced cell death in MeCP2 null cerebellar granule neurons exposed to excitotoxicity and hypoxia. Neuroscience 150(3), 563-74

Samaco RC, Hogart A, LaSalle JM (2005): Epigenetic overlap in autism-spectrum neurodevelopmental disorders: MECP2 deficiency causes reduced expression of UBE3A and GARBR3. Hum Mol Genet 14(4), 483-92

Samaco RC, McGraw CM, Ward CS, Sun Y, Neul JL, Zoghbi HY (2013): Female Mecp2 ${ }^{+/}$mice display robust behavioral deficits on two different genetic backgrounds providing a framework for pre-clinical studies. Hum Mol Genet 22, 96-109

Savard A, Lavoie K, Brochu M-E, Grbic D, Lepage M, Gris D, Sebire G (2013): Involvement of neuronal $\mathrm{IL}-1 \beta$ in acquired brain lesions in a rat model of neonatal encephalopathy. J Neuroinflammation 10(1), 1-14

Schanen NC, Roth Dahle EJ, Capozzoli F, Holm VA, Zoghbi HY, Francke U (1997): A new Rett syndrome family consistent with $X$-linked inheritance expands the $X$ chromosome exclusion map. Am J Hum Genet 61, 634-41

Schüle B, Armstrong DD, Vogel H, Oviedoe A, Francke U (2008): Severe congenital encephalopathy caused by MECP2 null mutations in males: central hypoxia and reduced neuronal dendritic structure. Clin Genet 74, 116-126 


\section{References}

Semenza GL, Roth PH, Fang HM, Wang GL (1994): Transcriptional regulation of genes encoding glycolytic enzymes by hypoxia inducible factor 1 . J Biol Chem 269(38), 23757-63

Shahbazian M, Young J, Yuva-Paylor L, Spencer C, Antalffy B, Noebels J, Armstrong D, Paylor R, Zoghbi HY (2002): Mice with truncated MeCP2 recapitulate many Rett syndrome features and display hyperacetylation of histone H3. Neuron 35(2), 243-54

Shalak L, Perlman JM (2004): Hypoxic-ischemic brain injury in the term infant-current concepts. Early Hum Dev 80(2), 125-41

Shibusawa N, Hashimoto K, Yamada M (2008): Thyrotropin-releasing hormone (TRH) in the cerebellum. Cerebellum 7(1), 84-95

Smeets EEJ, Pelc K, Dan B (2012): Rett syndrome. Mol Syndromol 2, 113-27

Smith JC, Ellenberger HH, Ballanyi K, Richter DW, Feldmann JL (1991): Pre-Bötzinger complex: a brainstem region that may generate respiratory rhythm in mammals. Science $254,726-9$

Smith JC, Butera RJ, Koshiya N, Del Negro C, Wilson CG, Johnson SM (2000): Respiratory rhythm generation in neonatal and adult mammals: the hybrid pacemaker-network model. Resp Physiol 122 , $131-47$

Smith ML, Auer RN, Siesjö BK (1984): The density and distribution of ischemic brain injury in the rat following 2-10 min of forebrain ischemia. Acta Neuropathol 64, 319-332

Southall DP, Kerr AM, Tirosh E, Amos P, Lang MH, Stephenson JBP (1988): Hyperventilation in the awake state: potentially treatable component of Rett syndrome. Arch Dis Child $\underline{63}, 1039-48$

Sprang GK, Brown IR (1987): Selective induction of a heat shock gene in fibre tracts and cerebellar neurons of the rabbit brain detected by in situ hybridization. Mol Brain Res $\underline{3}, 89-93$

Stearns NA, Schaevitz LR, Bowling H, Nag N, Berger UV, Berger-Sweeney J (2007): Behavioral and anatomical abnormalities in Mecp2 mutant mice: a model for Rett syndrome. Neuroscience 146(3), $907-21$

Stettner GM, Huppke P, Gärtner J, Richter DW, Dutschmann M (2008): Disturbances of breathing in Rett syndrome: results from patients and animal models. Adv Exp Med Biol 605, 503-7

Suzuki T, Kohno H, Sakurada T, Tadano T, Kisara K (1982): Intracranial injection of Thyrotropin releasing hormone $(\mathrm{TRH})$ suppresses starvation-induced feeding and drinking in rats. Pharmacol Biochem Be 17, 249-53

Szaflarski J, Burtrum D, Silverstein FS (1995): Cerebral hypoxia-ischemia stimulates cytokine gene expression in perinatal rats. Stroke $26,1093-100$

Tanimoto K, Makino Y, Pereira T, Poellinger L (2000): Mechanism of regulation of the hypoxia-inducible factor-1 $\alpha$ by the von Hippel-Lindau tumor suppressor protein. Embo J 19(16), 4298-309 


\section{References}

Trappe R, Laccone F, Cobilanschi J, Meins M, Huppke P, Hanefeld F, Engel W (2001): MECP2 mutations in sporadic cases of Rett syndrome are almost exclusively of paternal origin. Am J Hum Genet 68(5), 1093-101

Trollmann R, Rehrauer H, Schneider C, Krischke G, Huemmler N, Keller S, Rascher W, Gassmann M (2010): Hypoxia and the hypoxia-inducible-factor pathway in glioma growth and angiogemesis. Lategestational systemic hypoxia leads to a similar early gene response in mouse placenta and developing brain. Am J Physiol 299(6), 489-99

Unternaehrer E, Luers P, Mill J, Dempster E, Meyer AH, Staehli S, Lieb R, Hellhammer DH, Meinlschmidt G (2012): Dynamic changes in DNA methylation of stress-associated genes (OXTR, BDNF) after acute psychosocial stress. Transl Psychiatry 2, 2158-3188

Van Uden P, Kenneth NS, Rocha S (2008): Regulation of hypoxia-inducible factor-1a by NF-kB. Biochem J 412, 477-84

Vannucci SJ, Seaman LB, Vannucci RC (1996): Effects of hypoxia-ischemia on GLUT1 and GLUT3 glucose transporters in immature rat brain. J Cerebr Blood F Met 17, 77-81

Viemari JC, Roux JC, Tryba AK, Saywell V, Burnet H, Pena F, Zanella S, Bevengut M, BarthelemyRequin M, Herzing LBK (2005): Mecp2 deficiency disrupts norepinephrine and respiratory systems in mice. J Neurosci 25(50), 11521-30

Villard L (2007): MECP2 mutations in males. J Med Genet 44, 417-23

Vogelgesang S (2013): Identifying target genes related to respiratory network dysfunction in a mouse model for the Rett syndrome. Diss. Göttingen 2012

Ward CS, Arvide EM, Huang TW, Yoo J, Noebels JL, Neul JL (2011): MeCP2 is critical within HoxB1derived tissues of mice for normal lifespan. J Neurosci 31(28), 10359-70

Warnecke C, Zaborowska Z, Kurreck J, Erdmann VA, Frei U, Wiesener M, Eckardt KU (2004): Differentiating the functional role of hypoxia-inducible factor (HIF)-1 $\alpha$ and HIF-2 $\alpha$ (EPAS-1) by the use of RNA interference: erythropoietin is a HIF-2 $\alpha$ target gene in Hep3B and Kelly cells. FASEB J $18,1462-4$

Watson P, Black G, Ramsden S, Barrow M, Super M, Kerr B, Clayton-Smith J (2001): Angelman syndrome phenotype associated with mutations in MECP2, a gene encoding a methyl CpG binding protein. J Med Genet 38, 224-8

Weese-Mayer DE, Lieske SP, Boothby CM, Kenny AS, Bennett HL, Ramirez JM (2008): Autonomic dysregulation in young female children with Rett syndrome during nighttime in-home recordings. Pediatr Pulm 43, 1045-60

Wenger $\mathrm{RH}$ (2002): Cellular adaptation to hypoxia: $\mathrm{O}_{2}$-sensing protein hydroxylases, hypoxia-inducible transcription factors and $\mathrm{O}_{2}$-regulated gene expression. FASEB J 16, 1151-62 


\section{References}

Wiener CM, Booth G, Semenza GL (1996): In vivo expression of mRNAs encoding hypoxia-inducible factor 1. Biochem Bioph Res Co 225(2), 485-8

Yano N, Lou LG (2004): Effect of Thyrotropin releasing hormone (TRH) on gene expressions in rat pancreas: approach by microarray hybridization. J Pancreas 5(4), 193-204

Yu AY, Frid MG, Shimoda LA, Wieder CM, Stenmark K, Semenza GL (1998): Temporal, spatial, and oxygen-regulated expression of hypoxia-inducible factor-1 in the lung. Am J Physiol- Lung C 275 , L818-26

Yue X, Mehmet H, Penrice J, Cooper C, Cady E, Wyatt JS, Reynolds EOR, Edwards AD, Squier MV (1997): Apoptosis and necrosis in the newborn piglet brain following transient cerebral hypoxiaischaemia. Neuropath Appl Neuro 23, 16-25

Zachariah RM, Rastegar M (2012): Linking epigenetics to human disease and Rett syndrome: the emerging novel and challenging concepts in MeCP2 research. Neural Plast 2012, 1-10

Zanella S, Mebarek S, Lajard AM, Picard N, Dutschmann M, Hilaire G (2008): Oral treatment with desipramine improves breathing and life span in Rett syndrome mouse model. Respir Physiol Neurobiol 160(1), 116-21

Zauner A, Muizelaar JP: Head Injury. Brain metabolism and cerebral blood flow. Chapman and Hall, London 1997

Zhang X, Van den Pol AN (2012): Thyrotropin-releasing hormone inhibits melanin concentrating hormone neurons- implications for TRH mediated anorexic and arousal actions. J Neurosci 32(9), $3032-43$

Zhou Z, Hong E, Cohen S, Zhao WN, Ho HY, Schmidt L, Chen WG, Lin Y, Savner E, Griffith EC (2006): Brain-specific phosphorylation of MeCP2 regulates activity-dependent Bdnf transcription, dendritic growth, and spine maturation. Neuron $\underline{52(2)}$, 255-69

Zinkernagel AS, Johnson RS, Nizet V (2007): Hypoxia inducible factor (HIF) function in innate immunity and infection. J Mol Med 85, 1339-46

Zwillich C, Delvin T, White D, Douglas N, Weil J, Martin R (1982): Bradycardia during sleep apnea. J Clin Invest $\underline{69}, 1286-92$ 


\section{Acknowledgements}

First of all I would like to thank my academic supervisor PD Dr. Dr. Till Manzke for the assumption of this dissertation, his various suggestions and worthwhile advices. I enjoyed our friendly relationship that existed from the very beginning.

Special thanks goes to my supporting and very professional counselor Dr. Steffen Vogelgesang, without whose remarkable help and energetic support this work would never have been started nor terminated. His numberless hours of assistance served me as a fundament for performing my experiments as well as getting through the time of writing on this promotion.

For conscientious corrections I would like to thank all involved persons. In this connection particularly mentionable helpful proofreaders are Christian Grahle and Zoe Eleanor Allen.

Furthermore, I want to thank all my friends, relatives and fellow students who always motivated me with encouragement, advices and working hours together within the library so that this work could become completed faster. 


\section{Lebenslauf}

Mein Name ist Susann Özel und ich wurde in Hannover am 04.11.1984 geboren.

Meine Schulbildung absolvierte ich von 1990 bis 2000 in Gehrden. Von 2000 bis 2004 besuchte ich das Hannah-Arend-Gymnasium in Barsinghausen. Ich habe mein Abitur mit der Note 2,4 bestanden.

Von 2004 - 2007 habe ich den Beruf der Gesundheits- und Kinderkrankenpflegerin am Kinderkrankenhaus auf der Bult erlernt und mit bestandener Abschlussprüfung beendet.

Nach einem Jahr Aupair-Aufenthalt in Virginia, USA, setzte ich meinen beruflichen Werdegang 2007 mit dem Studium der Zahnmedizin an der Medizinischen Hochschule Hannover fort. Im Jahr 2009 wechselte ich den universitären Ausbildungsbetrieb und führte das Studium an der Universitätsmedizin Göttingen (UMG) fort.

Seit 2009 untersuchte ich in der neurophysiologischen Abteilung der UMG unter der Leitung von Herrn PD Dr. Dr. Manzke im Rahmen meiner experimentellen Dissertation mit dem Titel „Investigating the Impact of Hypoxia on Gene Expression in the Brain of a Mouse Model for the Rett Syndrome", ob die beschriebenen Atmungsstörungen von MeCP2 defizienten Mäusen zu einer durch zerebrale Hypoxie induzierten Veränderung der Genexpression führt.

Am 21.05.2014 habe ich das Staatsexamen der Zahnmedizin an der UMG bestanden. 